JOSÉ ANTONIO PORTES JUNIOR

\title{
DETECÇÃO DA PROTEÍNA PLP2 EM GLIOBLASTOMAS
}

Dissertação apresentada ao Programa de Pós-

Graduação Interunidades em Biotecnologia USP/Instituto Butantan/IPT, para obtenção do Título de Mestre em Biotecnologia. 


\section{JOSÉ ANTONIO PORTES JUNIOR}

\section{DETECÇÃO DA PROTEÍNA PLP2 EM GLIOBLASTOMAS}

Dissertação apresentada ao Programa de PósGraduação Interunidades em Biotecnologia USP/Instituto Butantan/IPT, para obtenção do Título de Mestre em Biotecnologia.

Área de concentração: Biotecnologia

Orientador: Dr. Geraldo Santana Magalhães

\section{São Paulo}


DADOS DE CATALOGAÇÃO NA PUBLICAÇÃO (CIP)

Serviço de Biblioteca e Informação Biomédica do

Instituto de Ciências Biomédicas da Universidade de São Paulo

reprodução não autorizada pelo autor

Portes Junior, José Antonio.

Detecção da proteína PLP2 em glioblastomas / José Antonio Portes Júnior. -- São Paulo, 2010.

Orientador: Geraldo Santana Magalhães.

Dissertação (Mestrado) - Universidade de São Paulo. Instituto de Ciências Biomédicas. Programa de Pós-Graduação Interunidades em Biotecnologia USP/IPT/Instituto Butantan. Área de concentração: Biotecnologia. Linha de pesquisa: Biologia Molecular.

Versão do título para o inglês: Detection of PLP2 protein in glioblastomas.

Descritores: 1. PLP2 2. Astrocitomas 3. Clonagem 4. Produção de anticorpos 5. Distribuição celular 6. Glioblastoma I. Magalhães, Geraldo Santana II. Universidade de São Paulo. Instituto de Ciências Biomédicas. Programa de Pós-Graduação em Biotecnologia III. Título. 
Candidato(a): $\quad$ José Antonio Portes Júnior.

Título da Dissertação: Detecção da proteína PLP2 em glioblastomas.

Orientador(a): $\quad$ Geraldo Santana Magalhães.

A Comissão Julgadora dos trabalhos de Defesa da Dissertação de Mestrado, em sessão pública realizada a ./..................................,
( ) Aprovado(a)
( ) Reprovado(a)

Examinador(a): Assinatura:

Nome:

Instituição:

Examinador(a): Assinatura:

Nome:

Instituição:

Presidente: Assinatura:

Nome:

Instituição: 


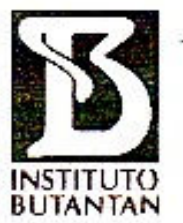

COMISSÃO DE ÉTICA NO USO DE ANIMAIS

INSTITUTO BUTANTAN

Av. Vital Brazil, [500, CEP 05503-900, Såo Paulo, SP, Brazil

Telefone: (55) (011) 3726-7222 ramal 2106 - Fax: (55) (011) 3726-1 505

\section{CERTIFICADO}

Certificamos que o Protocolo para uso de animais em experimentação $n^{\circ}$ 258/06, sobre o projeto intitulado "Produçāo de anticorpos contra proteinas recombinantes purificadas produzidas em E.coli", sob a responsabilidade de Paulo Lee Ho está de acordo com os Princípios Éticos na Experimentação Animal adotado pelo Colégio Brasileiro (COBEA) e foi aprovado pela COMISSÃO DE ÉTICA NO USO DE ANIMAIS DO INSTITUTO BUTANTAN (CEUAIB) em reuniāo de 14/03/2006.

São Paúlo, 17 de março de 2006.

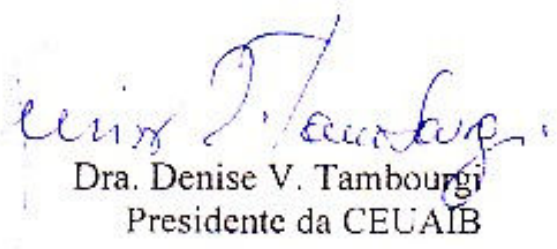

De acordo:

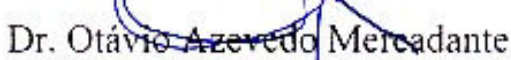

Diretor do Instituto Butantan 


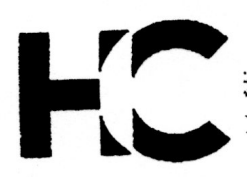

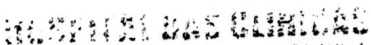

\section{APROVACEÃO}

A Comissão de Ética para Análise de Projetos de Pesquisa - CAPPesia da Diretoria Clínica do Hospital das Clínicas e da Faculdade de Medicina da Universidade de São Paulo, em sessão de 14.09.05. APROV'OU o Protocolo de Pesquisa $n^{\circ}$ 691/05, intitulado: "Procura de marcadores moleculares relacionados ao diagnóstico e prognóstico de tumores do sistema nervoso central" apresentado pelo Departamento de NEUROLOGIA.

Cabe ao pesquisador elaborar e apresentar à CAPPesq, os relatórios parciais e final sobre a pesquisa (Resolução do Conselho Nacional de Saúde $n^{\circ} 196$, de 10.10.1996, inciso IX. 2, letra "c")

Pesquisador(a) Responsável: Profa. Dra. Suely Kazue Nagahashi Marie

CAPPesq, 14 de Setembro de 2005.

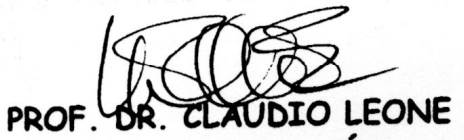

Vice-Presidente da Comissão de Ética para Análise de Projetos de Pesquisa

Comissáo de Etica para Anátise de Projetos de Pesquisa do HCFMUSP e da FMUSP Saulo Diretoria Clinica do Hospital das Clinicas da Faculdade de Medicina da Universidade de 
A Deus, por nunca ter me abandonado e sempre ter guiado todos os meus caminhos durante toda a minha vida. 
A minha família, pelo esforço, dedicação e compreensão, em todos os momentos desta e de outras caminhadas. 
A Aline, minha amada esposa, por sempre estar ao meu lado durante toda essa caminhada, pela paciência e amor dedicado a mim. Te amo muito. 


\section{AGRADECIMENTOS}

À Deus pelo dom da vida, renovado a cada provação que se apresenta e nos sonhos que se concretizam, como este que agora se torna realidade.

À minha mãe Cláudia, que me deu a vida com amor e sempre me apoiou em todas as minhas decisões, sempre querendo me ver feliz.

À minha esposa Aline, por todo amor, carinho, incentivo e apoio em todos os momentos difíceis fazendo-os parecerem fáceis.

Ao meu orientador e amigo Dr. Geraldo Santana Magalhães que muito admiro sua sabedoria, agradeço pela orientação e pelo constante incentivo, sempre indicando a direção a ser tomada nos momentos de maior dificuldade. Agradeço, pelos ensinamentos e confiança depositada no meu trabalho de dissertação.

À Coordenação de Aperfeiçoamento de Pessoal de Nível Superior (CAPES) pelo apoio financeiro.

Ao grande amigo Dr. Diego Butera pelo incentivo que me deu quando decidi encarar esse desafio.

À Dra. Suely Marie, a que eu devo a oportunidade de ter conseguido realizar um sonho abrindo as portas de seu laboratório, agradeço pela colaboração e receptividade.

À Dra. Irene Fernandes, por ter me aberto as portas para a pesquisa.

À Dra. Ana Maria Moura da Silva, diretora do Laboratório de Imunopatologia, pelo auxílio na revisão da defesa e pela oportunidade e incentivo à carreira científica.

À Dra. Kátia Cristina Barbaro, pelas sugestões, conversas e ajuda na revisão da defesa.

À querida Dra. Eliana Faquim de Lima Mauro pelo auxílio na revisão da qualificação e defesa e também pelas sugestões e apoio.

À grande amiga Dra. Maísa Splendore Della Casa, para quem as palavras são pouco para agradecer as valiosas sugestões e o companheirismo e amizade destes anos.

Ao Dr. Fábio Nascimento, pela valiosa colaboração nos experimentos de microscopia confocal que abriu novas perspectivas para este trabalho.

À Juliana Branco Novo, pela grande ajuda na padronização dos experimentos de western blotting. 
À Dra. Patrícia Bianca Clissa por todos os ensinamentos que me passou logo que cheguei ao laboratório.

Aos amigos do Laboratório de Imunopatologia: Bruna, Daiana, Stella, Cris Caporrino, Podé, Louise, Renata, Isa, lara, Sandriana, Cris Baldo, Priscila, Caio, Tamires, Fukuda, Sérgio, Amanda, Tiago, Cleusa, Gerson, Jovelino, Chiquinho, Iranildes, Juçara, Nicole, Josefa, pelo apoio, torcida e amizade.

Aos amigos do LIM 15: Sueli, Mazé, Mussya, Roseli, Miyuki, por toda ajuda durante este trabalho.

Ao meu amigo Márcio por ter paciência e aturar as minhas manias durantes estes anos.

Aos membros da secretaria da Biotecnologia.

A todos os professores do Programa de Pós Graduação em Biotecnologia da USP, pelos valiosos ensinamentos.

A todos os membros que participaram da minha banca de qualificação e defesa contribuindo com suas críticas e sugestões.

A todos que de alguma maneira contribuíram para a realização deste trabalho.

Obrigado por tudo! 
"Uma paixão forte por qualquer objeto assegurará o sucesso, porque o desejo pelo objetivo mostrará os meios." 


\section{RESUMO}

Portes Jr JA. Detecção da proteína PLP2 em glioblastomas. 2010. 83 f. Dissertação (Mestrado em Biotecnologia). Universidade de São Paulo, Instituto de Biociências, São Paulo, 2010.

Os astrocitomas correspondem à grande maioria dos gliomas, e são classificados segundo a organização mundial de saúde (OMS) em quatro subgrupos: astrocitoma pilocítico (grau I), astrocitoma de baixo grau (grau II), astrocitoma anaplásico (grau III) e glioblastoma multiforme (grau IV). Recentemente, com o intuito de identificar genes associados com invasão e proliferação tumoral, identificamos por PCR em tempo real, aumento de aproximadamente cem vezes da PLP2 em glioblastomas em relação a tecidos normais. Embora existam pouquíssimos estudos sobre esta proteína, um dos trabalhos mostra que a PLP2 encontra-se associada com um receptor de quimiocina (CCR1) acoplado a proteína $G$, e que pode ter um papel importante em processos quimiotáticos via CCR1. Até o momento não há nenhum relato da identificação desta proteína em astrocitomas. Portanto, neste trabalho clonamos e expressamos em bactérias as alças externas da proteína PLP2 em fusão com a proteína SUMO, com o objetivo de obtermos anticorpos policlonais para serem utilizados na identificação da PLP2 em astrocitomas. Para tanto, a proteína recombinante SUMO/PLP2a foi inoculada em camundongos e os anticorpos policlonais obtidos foram utilizados para a identificação da PLP2 por western blotting em linhagens celulares de glioblastoma U87MG, A172, e em extrato total de tecido normal e tumoral (GBM) humano. Os resultados mostraram que o anti-SUMO/PLP2a foi capaz tanto de reconhecer a PLP2 nativa nas linhagens celulares quanto no tecido tumoral, ao passo que não houve reconhecimento no tecido normal. Este resultado mostra a eficácia da PLP2 recombinante em induzir a produção de anticorpos contra a PLP2 nativa, os quais podem vir a ser de grande importância para a detecção e estudo desta proteína em outros tecidos ou serem usados como marcadores tumorais. Além da produção de anticorpos, realizamos a expressão desta proteína em células de mamífero para estudar sua distribuição celular. Para isto, a PLP2 foi clonada em fusão com a EGFP e expressa em células CHO, posteriormente análises por microscopia confocal revelaram que a PLP2 se 
concentrava em toda a membrana celular indicando ser esta, realmente uma proteína de membrana.

Palavras-chave: PLP2. Glioblastomas. Clonagem. Produção de anticorpos. Distribuição celular. 


\begin{abstract}
Portes Jr JA. Detection of PLP2 protein in glioblastomas. 2010. 83 p. Master Thesis (Biotechnology). Universidade de São Paulo, Instituto de Biociências, São Paulo, 2010.
\end{abstract}

Astrocytomas account for the large majority of gliomas, and are classified according to World Health Organization (WHO) into four groups: pilocytic astrocytoma (grade I), low-grade astrocytoma (grade II), anaplastic astrocytoma (grade III) and glioblastoma multiforme (grade IV). Recently, in order to identify genes associated with tumoral invasion and proliferation, it was identified by real time PCR, an increase of about one hundred times of PLP2 in glioblastomas when compared to normal tissue. Although there are few studies on this protein, one of them show that this protein is associated with a chemokine receptor (CCR1) coupled to G protein, and PLP2 may have an important role in chemotactic processes via CCR1. So far, there is no report of identification of this protein in astrocytomas. Therefore in this study, we cloned and expressed in bacteria the external handles of PLP2 protein fused with SUMO protein in order to obtain polyclonal antibodies for use in identifying the PLP2 in astrocytomas. Therefore, the recombinant SUMO/PLP2a was inoculated into mice and the obtained polyclonal antibodies was used to identify the PLP2 by western blotting in glioblastoma cell lines U87MG, A172 and in full extract of normal tissue and human tumor (GBM). The results showed that the anti-SUMO/PLP2a was able both to recognize the native PLP2 in the cell lines and also in tumor tissue, whereas no recognition was observed in normal tissue. This result shows the effectiveness of recombinant PLP2 to induce antibodies against PLP2 and that these antibodies might be of great valuefor the detection and study of this protein in other tissues or be used as tumor markers. Besides the production of antibodies, we performed the expression of this protein in mammalian cells in order to study its cellular localization. To that end, PLP2 was cloned in fusion with EGFP and expressed in CHO cells. Confocal microscopy revealed that PLP2 focused across the cell membrane indicating that this protein is in fact a membrane protein. 
Keywords: PLP2. Glioblastomas. Cloning. Production of antibodies. Cellular distribution. 


\section{LISTA DE ABREVIATURAS}

2YT - Meio bacto-triptona

a-MEM - Meio Mínimo Essencial

$\mathbf{g g}$ - Micrograma

$\mu \mathrm{L}-$ Microlitro

$\mu \mathrm{M}$ - Micro Molar

AP - Astrocitoma Pilocítico

BSA - Soro Albumina Bovina

$\mathrm{CaCl}_{2}-$ Cloreto de cálcio

cDNA - DNA complementar

DMEM - Meio Mínimo Essencial de Dulbecco

DO $_{595}$ - Densidade Óptica em 595 nanômetros

DO $_{600}$ - Densidade Óptica em 600 nanômetros

EGFP - Enhanced Green Fluorescent Protein

EST - Etiquetas de sequências expressas

g - Grama

GBM - Glioblastoma Multiforme

$\mathrm{H}_{2} \mathrm{O}$ - Água

IMAC - Cromatografia de Afinidade por Íons Metálicos Imobilizados

IPTG - Isopropyl $\beta$-D-1-thiogalactopyranoside

Kb - Quilo bases

$\mathrm{KCl}$ - Cloreto de potássio

KDa - Quilo Daltons

LB - Meio Luria-Bertani

M - Molar

mA - Miliampere

$\mathrm{MgCl}_{2}-$ Cloreto de magnésio

$\mathbf{M g S O}_{4}-$ Sulfato de magnésio

$\mathrm{mL}$ - Mililitro

mm - Milímetro

mM - Milimolar

MPSS - Sequenciamento Massivo de Assinatura Paralela

$\mathrm{NaCl}$ - Cloreto de sódio

$\mathrm{NaOH}$ - Hidróxido de sódio

ng - Nano grama

nm - Nanômetros

OMS - Organização Mundial de Saúde

pb - Pares de bases

PBS - Tampão fosfato-salino

PCR - Reação da Polimerase em Cadeia

rpm - Rotações por minuto

SAGE - Análise Serial de Expressão Gênica

SDS - Dodecil sulfato de sódio

SDS-PAGE - Eletroforese em gel de poliacrilamida com presença de SDS

SNC - Sistema Nervoso Central

Tris/NaCl - Tampão tris-salina

Tris- $\mathrm{HCl}$ - Tris hidrocloreto 


\section{LISTA DE SÍMBOLOS}

\section{AMINOÁCIDOS}

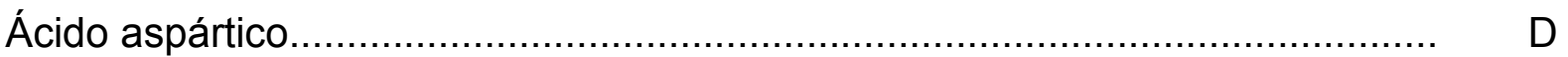

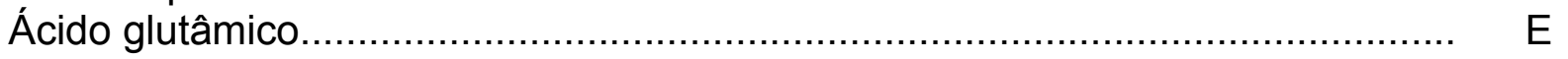

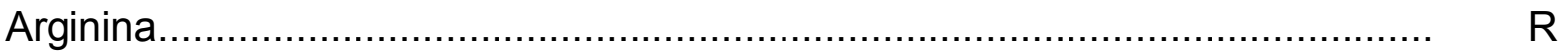

Asparagina.

Glutamina.

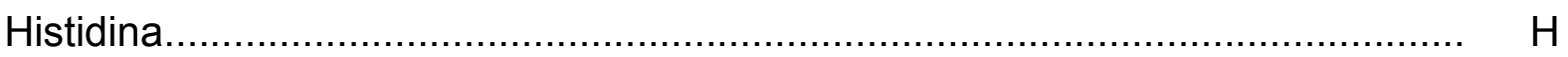

Lisina

Serina

Tirosina

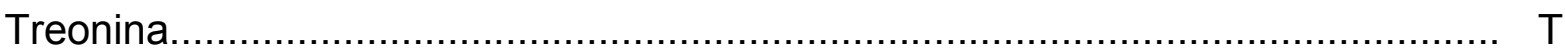

\section{BASES NITROGENADAS DOS NUCLEOTÍDEOS}

Adenina

Citosina

Guanina

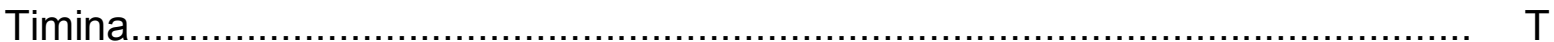


1 INTRODUÇÃO

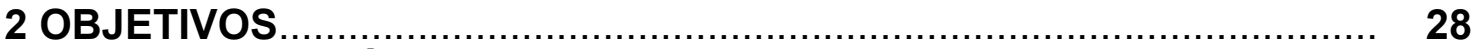

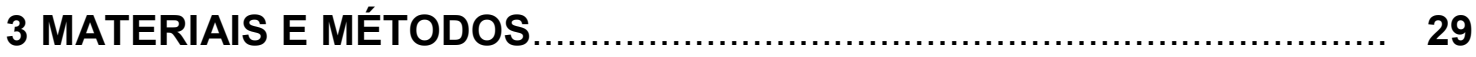

3.1 LINHAGENS BACTERIANAS .................................................... 29

3.2 LINHAGENS CELULARES ................................................ 30

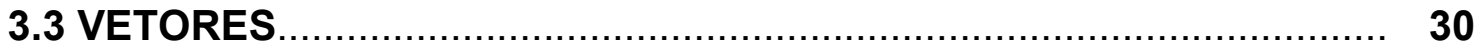

3.4 MEIOS DE CULTURA PARA BACTÉRIA (LB E 2YT) ..................... 31

3.5 PLACAS AGAR LB AMPICILINA/CANAMICINA ......................... 31

3.6 MATERIAIS UTILIZADOS PARA CULTURA DE CÉLULAS .............. 32

3.7 ANÁLISE DE BIOINFORMÁTICA........................................... 32

3.8 REAÇÃO DE POLIMERASE EM CADEIA (PCR) PARA CLONAGEM

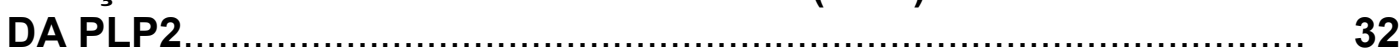

3.9 DIGESTÃO DE DNA COM ENZIMAS DE RESTRIÇÃO ….................... 35

3.10 EXTRAÇÃO DE PLASMÍDIO E PURIFICAÇÃO DE DNA DIGERIDO. 35

3.11 REAÇÃO DE LIGAÇÃO................................................... 35

3.12 SEQUENCIAMENTO DA PLP2 E PLP2a INSERIDAS NOS VETORES DE CLONAGEM.

3.13 PREPARAÇÃO DE E. coli COMPETENTE POR CLORETO DE CÁLCIO E TRANSFORMAÇÃO.

3.14 EXPRESSÃO DAS PROTEÍNAS RECOMBINANTES EM E. coli....... 38

3.15 EXTRAÇÃO DE PROTEÍNAS RECOMBINANTES DE BACTÉRIAS E. coli.

3.16 CROMATOGRAFIA DE AFINIDADE POR ÍONS METÁLICOS IMOBILIZADOS (IMAC)....

3.17 DOSAGEM DE PROTEÍNAS

3.18 ELETROFORESE EM GEL DE POLIACRILAMIDA COM SDS...........

3.19 SEQUENCIAMENTO POR ESPECTROMETRIA DE MASSA .............

3.20 PRODUÇÃO DO SORO ANTI-PLP2 EM CAMUNDONGOS .................

3.21 DOSAGEM DOS NÍVEIS DE ANTICORPOS POR ELISA ................ 42

3.22 WESTERN BLOTTING....................................................... 43

3.23 OBTENÇÃO DOS EXTRATOS TOTAIS DE CÉLULAS E TECIDOS.

3.24 IMUNOHISTOQUÍMICA

3.25 TRANSFECÇÃO PERMANENTE DOS VETORES pEGFP-N1/PLP2 E pEGFP-C3/PLP2 EM CÉLULAS CHO

3.26 ANÁLISE DOS CLONES POR MICROSCOPIA CONFOCAL............. 45

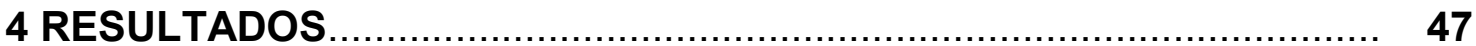

4.1 OBTENÇÃO DA PLP2 RECOMBINANTE ................................. 47

4.1.1 Clonagem da PLP2 no vetor pAE......................................... 47

4.1.2 Expressão da PLP2 no vetor PAE......................................... 50

4.1.3 Determinação das alças externas da PLP2 .............................. 50

4.1.4 Clonagem e expressão da PLP2a no vetor PAE........................ 52

4.1.5 Clonagem da PLP2a no vetor pSMT3 ….................................. 53

4.1.6 Expressão da proteína SUMO............................................. 56

4.1.7 Sequenciamento da proteína SUMO/PLP2a por espectrometria 
de massas......................................................................... 58

4.2 PRODUÇÃO DE ANTICORPOS POLICLONAIS CONTRA A PROTEÍNA RECOMBINANTE EM CAMUNDONGO ........................ 59

4.3 DETECÇÃO DA PLP2 EM GLIOBLASTOMA HUMANO .................... 61

4.3.1 Análise da especificidade do soro anti-SUMO/PLP2a contra a PLP2 nativa.

4.3.2 Detecção da PLP2 em tecido de glioblastoma humano.

4.4 IDENTIFICAÇÃO DA LOCALIZAÇÃO CELULAR DA PLP2 ................ 64

4.4.1 Clonagem da PLP2 nos vetores pEGFP-N1 e pEGFP-C3............. 64

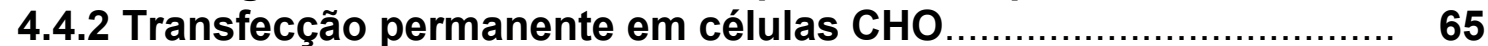

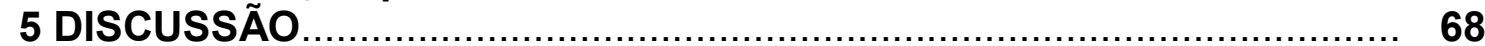

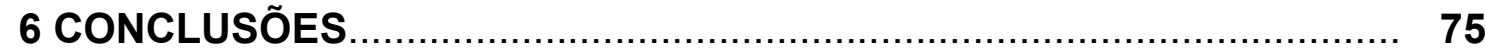

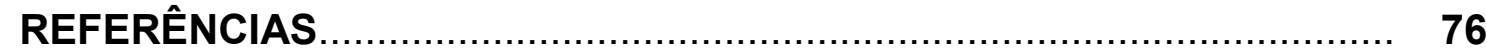




\section{INTRODUÇÃO}

Os tumores do sistema nervoso central (SNC) representam um grupo bastante heterogêneo de neoplasias originárias de tecido nervoso e meninges, com quatro graus de malignidade de acordo com a Organização Mundial de Saúde (LOUIS et al., 2007a). A classificação histológica destes tumores vem sendo um desafio há décadas, pois varia em relação ao tecido de origem, localização, padrão de disseminação, quadro clínico, história natural, idade de ocorrência e prognóstico (COLLINS, 2004).

A incidência de tumores malignos cerebrais em adultos é cerca de somente $2 \%$, levando-se em conta todas as neoplasias afetando, por exemplo, 4.400/ano no Reino Unido (MCKINNEY, 2004). Entretanto, em crianças, estes tumores representam o segundo câncer mais comum, superado apenas pelas leucemias, sendo o tumor sólido mais frequente. Nas últimas décadas, os avanços nas taxas de sobrevida global para estes tumores foram bastante modestos quando comparados a outras formas de malignidade em crianças, sendo que a taxa de mortalidade observada para o grupo dos tumores do SNC ainda é o maior dentre as neoplasias pediátricas.

O termo glioma é utilizado para designar os tumores (neoplasias) originários das células da glia encefálica. A glia é uma unidade formada por várias células que atuam como um sistema de sustentação dos neurônios e seus processos dendríticos e axonais, também têm um papel primário em grande variedade de funções normais e reações a lesões, incluindo inflamação, reparo, balanço hídrico e metabolismo energético. Essas células se encontram ao redor dos neurônios, assim como em meio aos axônios neuronais (COTRAN; KUMAR; COLLINS, 2000). A maior parte da glia, em termos quantitativos, pode ser encontrada na substância cinzenta encefálica e é formada por quatro células principais: astrócitos, oligodendrócitos, microglia e epêndima (Figura 1). 


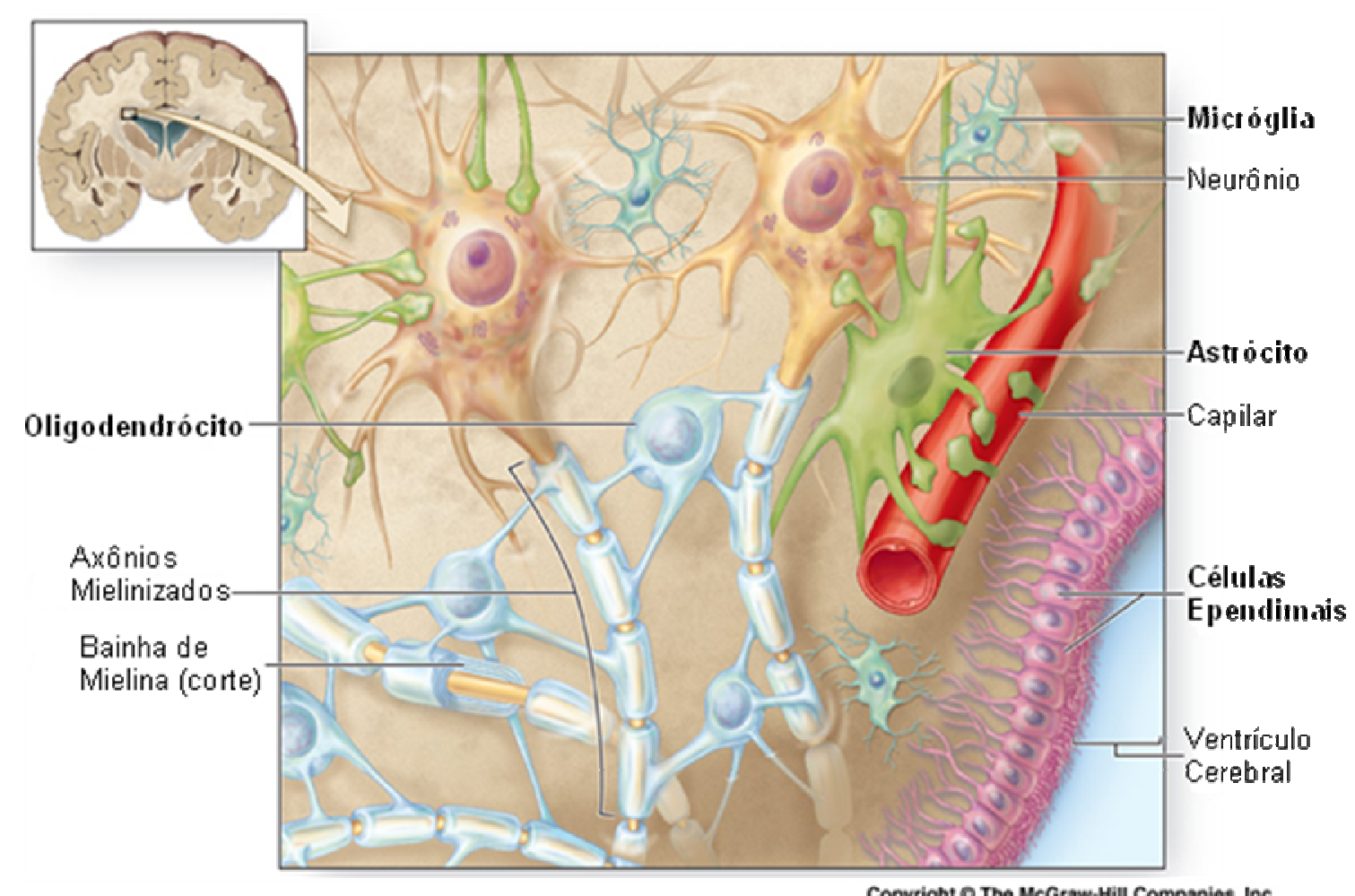

Figura 1. Figura ilustrando um corte da massa branca encefálica onde em negrito estão demonstradas as células da glia encefálica.

FONTE: Adaptado de KELLOGG COMMUNITY COLLEGE, 2010.

Os astrócitos são subdivididos em dois tipos celulares, os astrócitos protoplasmáticos (ocorrem principalmente na substância cinzenta) e os astrócitos fibrosos (presentes na substância branca e cinzenta). Alguns processos astrocíticos são dirigidos para neurônios e suas ações e sinapses, onde parecem atuar como tampões metabólicos ou desintoxicadores, fornecedores de nutrientes e isoladores elétricos. Outros circundam capilares ou se estendem às zonas subpiais e subependimárias, onde contribuem para as funções de barreira controlando o fluxo de macromoléculas entre o sangue, o líquor e o cérebro. Por fim, os astrócitos são as principais células responsáveis pelo reparo e formação de cicatrizes no cérebro (COTRAN; KUMAR; COLLINS, 2000).

Derivados dos tumores de tecido neuroepitelial (gliomas), os astrocitomas são os mais comumente observados tanto em adultos como em crianças. Estes tumores são heterogêneos, variando de tumores indolentes, como o astrocitoma pilocítico, até tumores altamente malignos, como o glioblastoma multiforme (GBM). Os gliomas são englobados em três grupos principais: astrocitomas, oligodendrogliomas e oligoastrocitomas mistos, que podem em geral ser diferenciados através de seus 
achados histológicos como: atipia nuclear, mitose, proliferação microvascular e necrose.

Os astrocitomas correspondem à grande maioria dos gliomas, perfazendo até $70 \%$ do total, e são classificados segundo a OMS (Tabela 1) em quatro subgrupos: astrocitoma pilocítico (AP) (grau I), astrocitoma de baixo grau (grau II), astrocitoma anaplásico (grau III) e glioblastoma multiforme (GBM) (grau IV) (VON DEIMLING et al., 1994; KLEIHUES et al., 2002). Respectivamente do menos agressivo para o de maior grau de agressividade.

TABELA 1- Classificação dos astrocitomas baseada em critérios histológicos.

\begin{tabular}{l|l}
\hline Classificação* & Critério Histológico \\
\hline Grau I - Astrocitoma pilocítico & Astrócitos bem diferenciados abundantes \\
\hline Grau II - Astrocitoma de baixo grau & $\begin{array}{l}\text { Atipia nuclear, citoplasma abundante e } \\
\text { alterações microcísticas }\end{array}$ \\
\hline Grau III - Astrocitoma anaplásico & Atipia nuclear e atividade mitótica \\
\hline Grau IV - Glioblastoma multiforme & $\begin{array}{l}\text { Atipia nuclear, mitose, proliferação } \\
\text { endotelial e/ou necrose }\end{array}$ \\
\hline
\end{tabular}

* (LOUIS et al., 2007a)

Os astrocitomas pilocíticos distinguem-se dos demais por sua aparência patológica e comportamento relativamente benigno, mesmo assim, em alguns casos possuem potencial de transformação maligna, tornando-se agressivos. São os astrocitomas mais frequentes em crianças a partir dos 5 anos de idade, porém podem acometer jovens adultos. Esses tumores crescem muito lentamente, e a cirurgia é o tratamento de escolha para tais lesões, alguns pacientes sobreviveram por mais de 40 anos após uma ressecção incompleta (COTRAN; KUMAR; COLLINS, 2000).

Os astrocitomas de baixo grau são tumores mais frequentes após os 30 anos de idade, podendo demorar em torno de 20 anos para se apresentarem sintomaticamente. Pacientes com este tipo de tumor podem ter anos de crises convulsivas antes da detecção por imagem da lesão e cerca de $50 \%$ dos casos evoluem para formas mais malignas (KLEIHUES et al., 2002). Neste tipo de tumor, a estimulação autócrina pelo fator de crescimento derivado de plaquetas juntamente com a inativação do gene p53, são fundamentais para o desenvolvimento deste tumor. Essas células também teriam respostas defeituosas no reparo do DNA danificado, aumentando a possibilidade de mudança maligna futura (LOUIS, 1997). Neste caso, o tratamento de escolha é a cirurgia, embora a radioterapia e 
quimioterapia tenham sido usados em alguns casos selecionados, porém com baixa resposta já que as células proliferam de forma lenta (LOUIS et al., 2007a).

Nos astrocitomas anaplásicos já ocorreu algum tipo de transformação maligna que confere ao tumor um potencial de maior agressividade. Suas células proliferam mais rapidamente e isso leva frequentemente a um rápido crescimento da massa tumoral, aumentando a pressão intracraniana e acarretando sintomas como cefaléia e vômitos, assim como deficiências motoras e problemas com a fala. Os pacientes acometidos por esses tumores apresentam menor sobrevida quando comparado aos dois anteriores. A cirurgia é o tratamento de escolha e após esta, a radioterapia e quimioterapia são empregadas (DAUMAS-DUPORT et al., 1988; LOUIS et al., 2007b).

Os glioblastomas multiformes (GBM) tem aparência histológica semelhante à do astrocitoma anaplásico, com as características adicionais de necrose e proliferação de células vasculares ou endoteliais - quando a proliferação das células vasculares é extrema, forma uma estrutura semelhante a uma bola, o corpo glomerulóide. O fator do crescimento de células endoteliais vasculares, produzido por astrócitos malignos, contribui para essa forma distinta de alteração vascular (COTRAN; KUMAR; COLLINS, 2000). Os GBMs são os mais agressivos dentre os astrocitomas, e apesar de esforços para desenvolver novas terapias, a sobrevivência média dos pacientes com este diagnóstico raramente excede 12 meses (KORSHUNOV; SYCHEVA; GOLANOV, 2005). Esses dados refletem a resistência deste tipo de tumor não somente a métodos cirúrgicos, mas também a quimioterapia e radioterapia. Cerca de $25 \%$ dos tumores cerebrais concentram-se entre os graus II a IV (LOUIS et al., 2007a).

A identificação de alterações moleculares envolvidas no estabelecimento de astrocitomas agressivos representa um grande desafio, especialmente àquelas que possam servir de alvos para agentes farmacológicos. Nesse sentido, tecnologias tais como cDNA microarrays, sequenciamento de EST (BRENTANI, et al., 2003), análise serial de expressão gênica (SAGE) (VELCULESCU et al., 1995) e sequenciamento massivo de assinatura paralela (MPSS) (JONGENEEL et al., 2003; GRIGORIADIS et al., 2006), tem se mostrado ferramentas poderosas para fornecer informações importantes sobre a natureza das alterações moleculares que levam ao estabelecimento e progressão de tumores. 
Dentre estas técnicas, a comparação de diferentes graus de tumores por microarray tem se tornado bem estabelecida para analisar o padrão de expressão gênica, pois possui grande potencial de fornecer elementos que permitam selecionar genes que possam ser utilizados como marcadores de prognóstico (DYRSKJOT, 2003; SÁNCHEZ-CARBAYO, 2003; CUPERLOVIC-CULF; BELACEL; OUELLETTE, 2005).

O desenvolvimento de gliomas é um processo complexo que envolve alteração de um grande número de genes, já foi observado que alterações genéticas estão relacionadas com a progressão dos tumores astrocíticos de baixo para alto grau, o que faz parte da história natural da doença em muitos pacientes (LOUIS, 1997). Vários destes genes já foram correlacionados com astrocitomas como Np95, LM01, FCGBP, DSCAM e TXLN, estes foram os primeiros genes identificados por análise de cDNA representacional diferenciada altamente expressos em astrocitomas anaplásicos humanos quando comparado com tecido do sistema nervoso não tumoral (OBA-SHINJO et al., 2005). Mutações somáticas de TP53 foram detectadas em 7,4\% de GBM analisados, 27,3\% em astrocitomas anaplásicos e $43 \%$ em astrocitomas de baixo grau, nunca antes verificado em pacientes brasileiros, este tipo de mutação em astrocitomas difusos é mais freqüente que descrito anteriormente (UNO et al., 2005). Um estudo de caso-controle analisou 200 pacientes com astrocitomas associando o polimorfismo encontrado no éxon 16 do fator de crescimento de epiderme, onde 96,5\% dos casos mostraram redução significativa do risco de desenvolvimento de astrocitomas mais agressivos (BARBOSA et al., 2008). O marcador de proliferação Ki-67 também tem sido usado para discriminar entre os graus de anaplasia nos astrocitomas, bem como em outros tipos de tumores cerebrais (HSU et al., 1997). A perda de uma cópia do cromossomo 10 (locus de TFAM), a trissomia dos cromossomos 7, 19 e 20 são eventos frequentes em glioblastomas, enquanto raro nos tumores astrocísticos de baixo grau (LOUIS et al., 2007a).

Recentemente, com o intuito de identificar genes associados com invasão e proliferação tumoral, Scrideli et al. (2008) compararam o padrão de expressão de 10.000 genes de tumores astrocíticos de grau IV (GBM) com o de grau I (AP), utilizando-se de técnicas de microarray. A opção por esse modelo de comparação usando estes dois tipos tumorais foi baseada na observação prévia de que, em 
geral, a comparação global do perfil de expressão de células normais com tumorais, gera centenas de genes diferencialmente expressos, sendo que muitos deles não apresentam papel crítico no processo tumorigênico. Esta observação foi confirmada quando quando GBM ou AP foram comparados à tecidos normais de cérebro e mais de 500 genes estiveram diferencialmente expressos em cada caso. Entretanto, quando foi comparado GBM com AP, somente 63 genes mostraram uma diferença de expressão maior que duas vezes.

Uma classificação funcional desses genes altamente expressos em GBM mostra que $40 \%$ estão relacionados com mitose e ciclo celular, e muitos destes têm sido relacionados com a transformação celular e aumento de malignidade em diferentes tipos de câncer, incluindo gliomas (RICKMAN et al., 2001; KHATUA et al., 2003; RHODES et al., 2004; COLIN et al., 2006).

Baseado nos dados obtidos por Scrideli et al. (2008), nosso grupo identificou por PCR em tempo real, o transcrito de uma proteína denominada proteína proteolipídica 2, também conhecida como PLP2 ou proteína A4. Conforme mostrado na figura 2, foi verificado que sua expressão em glioblastomas era aproximadamente cem vezes maior quando comparada com tecido não neoplásico (dados não publicados).

O gene da PLP2 foi inicialmente identificado em células epiteliais de cólon humano e cuja expressão mostrou-se dependente da diferenciação destas células (OLIVA; WU; YANG, 1993). Este gene codifica uma proteína de 17 kDa que apresenta 4 potenciais domínios transmembrânicos que se multimerizam para formar um canal iônico (BREITWIESER et al., 1997).

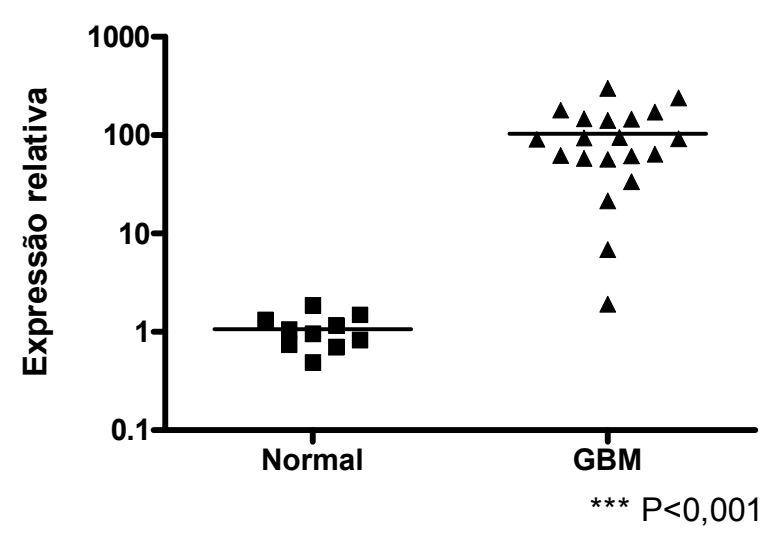

Figura 2. Nível de expressão de PLP2 em glioblastoma e tecido não neoplásico. Glioblastomas (GBM) e tecidos não-neoplásico (Normal) foram transcritos reversamente e os cDNAs foram analisados por QT-PCR. As barras horizontais mostram a média de cada grupo. *** Valor de significância de acordo com o teste de Mann-Whitney. 
A PLP2 possui um domínio MARVEL, este domínio foi identificado em proteínas da mielina e de linfócitos (MAL) das famílias de physins, gyrins e occludin. Estas proteínas que contém o domínio MARVEL estão relacionadas com o tráfico e ligação das vesículas de membrana, além de possuírem uma topologia em forma de $\mathrm{M}$, com quatro regiões transmembranares onde as regiões $\mathrm{N}$-terminal e C-terminal estão localizadas no citoplasma da célula, este domínio é bem conservado e está envolvido em eventos de aposição da membrana e uma variedade de processos celulares, tais como biogênese dos transportadores vesiculares (SANCHEZ-PULIDO et al., 2002).

A sequência completa do cromossomo X (ROSS et al., 2005) mostra que o gene da PLP2 está localizado neste cromossomo. A PLP2 também já foi encontrada em células piramidais do hipocampo e células granulares do cerebelo e foi visto que esta proteína tem alguma ligação com doenças que causam retardo mental ligado ao cromossomo X (ZHANG et al., 2007).

Lee et al. (2004) verificou que esta proteína se encontra predominantemente na membrana plasmática associada à proteína CCR1 em células de sarcoma osteogênico humano (HOS). O CCR1 é um receptor de quimiocina acoplado a proteína G. Neste trabalho, a utilização de agentes quimiotáticos em células que super expressam a PLP2 promoveu o aumento da migração celular, indicando um papel funcional da PLP2 em processos quimiotáticos via CCR1.

A ligação extracelular de quimiocinas aos seus receptores ativa diferentes vias de transdução de sinal. O domínio intracelular da CCR1 é composto de três alças e a parte C-terminal é responsável por traduzir o sinal das quimiocinas para promover a resposta celular (MURDOCH; FINN, 2000; BAGGIOLINI, 2001). A ligação quimiocina/CCR1 induz o influxo de cálcio, quimiotaxia e a inibição da adenilato ciclase (MYERS; WONG; CHARO, 1995; PEACE et al., 1998).

Existem pouquíssimos trabalhos sobre a PLP2, e esta é a primeira vez que se observa seu aumento em glioblastomas quando comparado com tecido normal. $O$ papel desta proteína na transformação maligna é totalmente desconhecido, mas devido sua associação com o receptor CCR1, que após ativação promove a migração celular, possa ser um alvo interessante de estudo do envolvimento desta proteína no processo tumorigênico dos astrocitomas, podendo favorecer metástase destas células tumorais. 
Até o momento, somente dados de expressão gênica foram obtidos em relação à PLP2, mas não há nenhum relato da identificação desta proteína em astrocitomas. Portanto, neste trabalho, decidimos estudar a expressão desta proteína em astrocitomas e comparar com o tecido normal. Além disso, realizamos estudos de localização celular da PLP2 através de sua expressão em células de mamífero. 


\section{OBJETIVOS}

Tendo em vista a grande importância da descoberta de novos genes que possam estar envolvidos de alguma forma com diversos tipos de neoplasias, este trabalho tem como objetivo, validar a presença da proteína proteolipídica 2 (PLP2) em tumores (glioblastoma) do sistema nervoso central.

Os objetivos específicos deste trabalho são:

$\checkmark$ Obtenção da PLP2 recombinante.

$\checkmark$ Produção de anticorpos policlonais contra a proteína recombinante em camundongos.

$\checkmark$ Detecção da PLP2 em glioblastoma humano.

$\checkmark$ Identificação da localização celular da PLP2. 


\section{MATERIAIS E MÉTODOS}

\subsection{LINHAGENS BACTERIANAS}

Todas as cepas utilizadas neste trabalho foram gentilmente cedidas pelo Laboratório de Biotecnologia do Instituto Butantan. São elas:

> BL21(DE3) SI: Estas células contém uma inserção cromossômica do gene da T7 RNA polimerase sob o controle do promotor proU (BHANDARI; GOWRISHANKAR, 1997).

> C43(DE3): A cepa C43 (DE3) foi derivada da cepa C41 (DE3) transformada com a subunidade do gene da F-ATPase, por sua vez a cepa C41 (DE3) foi derivada da cepa BL21 (DE3) [E. coli F-ompT hsdSB (Rb-MB)-gal DCM (DE3)], (MIROUX; WALKER, 1996). Essa cepa tem pelo menos uma mutação não caracterizada que impede a morte celular associada com a expressão de proteínas recombinantes tóxicas.

$>$ BL21 Star ${ }^{\mathrm{TM}}$ (DE3)pLysS: $\mathrm{F}^{-}$ompT $h s d \mathrm{~S}_{\mathrm{B}}\left(r_{\mathrm{B}}^{-} m_{\mathrm{B}}^{-}\right)$gal dcm rne131 (DE3) pLysS $\left(\mathrm{Cam}^{\mathrm{R}}\right)$.

DH5a: supE44 $\Delta a l c U 169(\phi 80 l a c Z \Delta M 15)$ hsdR17 recA1 endA1 gyra96 thi-1 relA1.

Bactérias contendo a designação (DE3) indicam que o hospedeiro é um lisógeno do fago $\lambda \mathrm{DE} 3$, portanto, carrega uma cópia do gene da T7 RNA polimerase em seu cromossomo sob o controle do promotor lacUV5, indutível por IPTG. A designação pLysS é dada para as bactérias carregando plasmídios compatíveis que codificam a lisozima T7, um inibidor natural da T7 RNA polimerase, que tem por finalidade promover melhor controle da expressão enquanto o IPTG não é adicionado no meio de cultura. 


\subsection{LINHAGENS CELULARES}

As linhagens celulares que foram utilizadas neste trabalho foram:

> CHO: Linhagem celular de ovário de Hamster chinês (Cricetulus griseus).

> U87MG: Linhagem celular imortalizada de glioblastoma humano.

> A172: Linhagem celular imortalizada de glioblastoma humano.

A linhagem $\mathrm{CHO}$ foi obtida do banco de células do Laboratório de Imunopatologia do Instituto Butantan e as linhagens U87MG e A172 foram gentilmente cedidas pela Dra. Suely Marie do Laboratório de Investigações Médicas (LIM15) da Faculdade de Medicina da Universidade de São Paulo (FMUSP).

\subsection{VETORES}

Os vetores utilizados para as clonagens e expressão da proteína recombinante foram:

> pAE: Plasmídio de $2.850 \mathrm{pb}$ derivado do pRSET A da Invitrogen (Invitrogen, Grand Island, N.Y., U.S.A.), o qual foi removido o gene T7 10 líder. Além disso, teve o epítopo Xpress $^{\mathrm{TM}}$ removido, que tinha a função de permitir a detecção da proteína de fusão com anticorpo contra este epítopo (RAMOS et al., 2001). Este plasmídio foi gentilmente cedido pelo professor Dr. Paulo Lee Ho do Laboratório de Biotecnologia do Instituto Butantan.

> pSMT3: O pSMT3 é um vetor de expressão com 5.633 pb. Na sua região 5'(N-terminal) tem o His-Tag que é separado da proteína de fusão SUMO (Śmall Úbiquitin-like Modifier) (BUTT et al., 2005) por um sítio de clivagem com trombina. Após a SUMO tem o sítio de múltipla clonagem, onde o gene de interesse foi inserido - região 3' (C-terminal).

> pEGFP-N1: Vetor de expressão em células de mamífero da empresa Clontech (BD Biosciences Clontech, Little Chalfont, Buckinghamshire, U.K.) com $4.7 \mathrm{~Kb}$, possui em sua sequência o gene da proteína EGFP (Enhanced Green Fluorescent Protein), uma variante melhorada da proteína GFP (Green 
Fluorescent Protein) selvagem. Este vetor possui resistência a canamicina e neomicina e seu promotor é de citomegalovírus (CMV). Neste vetor a porção C-terminal do gene a ser clonado fica fusionado com a porção N-terminal da EGFP, podendo assim ser expresso em células de mamífero e por conta da EGFP servir como um gene repórter pode-se visualizar sua expressão, pois a EGFP emite fluorescência quando excitada a um comprimento de onda de $488 \mathrm{~nm}$.

> pEGFP-C3: Este vetor também é da empresa Clontech e possui as mesmas características do pEGFP-N1, o que os diferem é que neste vetor a porção Nterminal do gene a ser clonado fica fusionado com a porção C-terminal da EGFP.

\subsection{MEIOS DE CULTURA PARA BACTÉRIA (LB E 2YT)}

Os meios utilizados para crescimento bacterianos foram o LB e $2 \mathrm{YT}$, cuja composição é dada abaixo:

\begin{tabular}{|lll|}
\hline Reagente & LB & 2YT \\
\hline Triptona & $10 \mathrm{~g}$ & $16 \mathrm{~g}$ \\
\hline Extrato de Levedura & $5 \mathrm{~g}$ & $5 \mathrm{~g}$ \\
\hline $\mathrm{NaCl}$ & $10 \mathrm{~g}$ & $5 \mathrm{~g}$ \\
\hline $\mathbf{H}_{2} \mathbf{O}$ (para vol. final) & $1000 \mathrm{~mL}$ & $1000 \mathrm{~mL}$ \\
\hline Ajustar o pH para $7,2 \mathrm{com} \mathrm{NaOH} 1 \mathrm{~N}$, e autoclavar por 20 minutos à $121^{\circ} \mathrm{C}$.
\end{tabular}

\subsection{PLACAS AGAR LB AMPICILINA/CANAMICINA}

Ao meio LB adiciona-se $1,5 \%$ de ágar, após dissolver bem, o meio é autoclavado por 20 minutos a $120^{\circ} \mathrm{C}$. Após a autoclavagem e quando a temperatura do meio estiver por volta de $50{ }^{\circ} \mathrm{C}$, adiciona-se ampicilina ou canamicina a uma concentração final de $100 \mu \mathrm{g} / \mathrm{mL}$. 


\subsection{MATERIAIS UTILIZADOS PARA CULTURA DE CÉLULAS}

Para as culturas das linhagens celulares foram utilizado os seguintes reagentes:

$\checkmark$ Meio mínimo essencial a-MEM contendo $10 \mathrm{mg} / \mathrm{L}$ de ribonucleosídeos e desoxiribonucleosídeos, marca Cultilab (Cultilab Materiais em Cultura de Células LTDA, Campinas, S.P., Brasil).

$\checkmark$ Meio mínimo essencial de Dulbecco (DMEM) High Glucose, marca Cultilab.

$\checkmark$ Soro fetal bovino inativado, marca Cultilab.

$\checkmark$ Tripsina, marca Sigma (Sigma-Aldrich Chemie, Steinhein, Germany).

$\checkmark$ Penicilina e estreptomicina, marca Invitrogen.

$\checkmark$ L-glutamina, marca Gibco (Gibco - Invitrogen, Grand Island, N.Y., U.S.A.).

$\checkmark$ Geneticina - G418, marca Invitrogen.

\subsection{ANÁLISE DE BIOINFORMÁTICA}

Para a determinação das alças externas da proteína PLP2 na membrana celular foi realizada uma análise utilizando o programa TMHMM Server v. 2.0 (www.cbs.dtu.dk/services/TMHMM/). Este programa analisa a sequência de aminoácidos da proteína predizendo assim as possíveis hélices transmembranares que ela possui pela determinação das regiões hidrofílicas e hidrofóbicas da proteína.

\subsection{REAÇÃO DE POLIMERASE EM CADEIA (PCR) PARA CLONAGEM DA PLP2}

Para a clonagem da PLP2 nos vetores de expressão foi realizada amplificação por PCR utilizando 100 ng de cDNA de astrocitomas gentilmente cedidos pela Dra. Suely Marie do Laboratório de Investigações Médicas (LIM15) da Faculdade de Medicina da Universidade de São Paulo (FMUSP). A clonagem da 
PLP2a foi realizada através da amplificação por PCR utilizando o gene sintético que foi sintetizado pela empresa IDT (Integrated DNA Technologies Inc., Coralville, IA, U.S.A.). A PLP2 e a PLP2a foram clonadas a partir do N-terminal (MADSE...) nos vetores pAE e pSMT3 utilizando os mesmos primers, para a clonagem da PLP2 nos vetores pEGFP-N1 e pEGFP-C3 foram desenhados novos primers:

Vetores pAE e pSMT3 (clonagem nos sítios de BamHI e Hind III)

Primer senso (sitio de BamHI em negrito)

5'-GACTGGATCCATGGCGGATTCTGAG-3'

Primer antisenso (sitio para Hind III em negrito)

5'-GAGAAGCTTTTACACCGGGCCATCTGC- 3'

Vetores pEGFP-N1 e pEGFP-C3 (clonagem nos sítios de Hind III e BamHI)

Primer senso (sítio de Hind III em negrito)

5' -GAGAAGCTTATGGCGGATTCTGAG- 3'

Primer antisenso para clonagem no vetor pEGFP-N1 (sítio de BamHI em negrito)

5' -GACTGGATCCCGCACCGGGCCATCTGC-3'

Primer antisenso para clonagem no vetor pEGFP-C3 (sítio de BamHI em negrito)

5' -GACTGGATCCTTACACCGGGCCATCTGC-3'

Para as clonagens foi utilizada a enzima Platinum® Taq DNA Polymerase High Fidelity (Invitrogen) que possui a alta fidelidade na amplificação gênica. Assim, foi utilizado $100 \mathrm{ng}$ de template contendo a sequência desejada e os reagentes e as concentrações utilizadas, bem como as condições de ciclagem no termociclador (Perkin-Elmer-2400), seguem abaixo.

\begin{tabular}{|l|l|}
\hline Reagentes & Concentração Final \\
\hline $10 X$ High Fidelity PCR Buffer & $1 \mathrm{X}$ \\
\hline $10 \mathrm{mM}$ dNTP & $0,2 \mathrm{mM}$ \\
\hline $50 \mathrm{mM} \mathrm{MgSO}{ }_{4}$ & $2 \mathrm{mM}$ \\
\hline $10 \mu \mathrm{M}$ primer 1 & $0,3 \mu \mathrm{M}$ \\
\hline $10 \mu \mathrm{M}$ primer 2 & $0,3 \mu \mathrm{M}$ \\
\hline Template & $100 \mathrm{ng}$ \\
\hline Platinum Taq High Fidelity & $2,5 \mathrm{U}$ \\
\hline $\mathrm{H}_{2} \mathrm{O}$ & Vol. para $50 \mu \mathrm{L}$ \\
\hline
\end{tabular}




\begin{tabular}{|c|c|c|}
\hline \multicolumn{3}{|c|}{ CICLAGEM } \\
\hline $94^{\circ} \mathrm{C}$ & $2 \mathrm{~min}$. & \\
\hline $\begin{array}{l}94^{\circ} \mathrm{C} \\
55^{\circ} \mathrm{C} \\
68^{\circ} \mathrm{C}\end{array}$ & $\begin{array}{l}30 \text { seg. } \\
30 \text { seg. } \\
45 \text { seg. }\end{array}$ & $35 X$ \\
\hline $\begin{array}{l}68^{\circ} \mathrm{C} \\
4{ }^{\circ} \mathrm{C}\end{array}$ & $\begin{array}{l}5 \text { min. } \\
\infty\end{array}$ & \\
\hline
\end{tabular}

Para selecionar os clones contendo a PLP2 e a PLP2a foi também utilizado o PCR, utilizando os primers senso e antisenso das extremidades de cada seqüência já descritos anteriormente. Neste caso, foi utilizado a Taq polimerase da Invitrogen. As colônias foram coletadas, inoculadas em $50 \mu \mathrm{l}$ de meio LB e incubadas a $37^{\circ} \mathrm{C}$ em por 2 horas. Para a reação foi utilizado $5 \mu \mathrm{l}$ dessa cultura para um volume final de $25 \mu \mathrm{l}$ da reação de PCR. Os reagentes com suas concentrações na reação final, bem como as condições de ciclagem seguem abaixo.

\begin{tabular}{|l|l|}
\hline Reagentes & Concentração Final \\
\hline $10 X$ Tampão & $1 \mathrm{X}$ \\
\hline $10 \mathrm{mM}$ dNTP & $0,2 \mathrm{mM}$ \\
\hline $50 \mathrm{mM} \mathrm{MgSO}{ }_{4}$ & $1,5 \mathrm{mM}$ \\
\hline $10 \mu \mathrm{M}$ primer 1 & $0,5 \mu \mathrm{M}$ \\
\hline $10 \mu \mathrm{M}$ primer 2 & $0,5 \mu \mathrm{M}$ \\
\hline Template & $5 \mu \mathrm{L}$ (da cultura) \\
\hline Taq Polymerase & $2,5 \mathrm{U}$ \\
\hline $\mathrm{H}_{2} \mathrm{O}$ & Vol. para $25 \mu \mathrm{L}$ \\
\hline
\end{tabular}

\begin{tabular}{|c|c|c|}
\hline \multicolumn{3}{|c|}{ CICLAGEM } \\
\hline $94{ }^{\circ} \mathrm{C}$ & 2 min. & \\
\hline $\begin{array}{l}94^{\circ} \mathrm{C} \\
55^{\circ} \mathrm{C} \\
72{ }^{\circ} \mathrm{C}\end{array}$ & $\begin{array}{l}30 \text { seg. } \\
30 \text { seg. } \\
45 \text { seg. }\end{array}$ & $35 X$ \\
\hline $\begin{array}{l}72^{\circ} \mathrm{C} \\
4{ }^{\circ} \mathrm{C}\end{array}$ & $\begin{array}{l}5 \text { min. } \\
\infty_{\infty} .\end{array}$ & \\
\hline
\end{tabular}




\subsection{DIGESTÃO DE DNA COM ENZIMAS DE RESTRIÇÃO}

As digestões foram realizadas em volume de $25 \mu \mathrm{l}$, e continham em geral $4 \mu \mathrm{g}$ de DNA, 2 unidades da enzima de restrição a ser usada da Fermentas (Fermentas Inc., Burlington, Ontario, Canadá), 1X o tampão da enzima e água deionizada para o ajuste do volume. Os produtos da reação foram então incubados por 4 horas a temperatura de $37^{\circ} \mathrm{C}$.

\subsection{EXTRAÇÃO DE PLASMÍDIO E PURIFICAÇÃO DE DNA DIGERIDO}

A extração dos plasmídios das bactérias $E$. coli $\mathrm{DH} 5 \alpha$ foi realizada utilizando o kit Wizard ${ }^{\circledR}$ Plus Minipreps da Promega (Promega Corporation, Madison, W.I., U.S.A.). A purificação dos fragmentos de PCR do gel de agarose e a limpeza dos produtos de digestão por enzimas de restrição foram realizados com o kit Wizard $^{\circledR}$ PCR Preps (Promega). Todos estes processos foram realizados seguindo a orientação do fabricante.

\subsection{REAÇÃO DE LIGAÇÃO}

As concentrações de DNA (vetor: inserto) utilizadas variaram de acordo com o experimento realizado, sendo normalmente a uma razão molar de 1:3. A reação de ligação foi efetuada utilizando $2 U$ de T4 DNA ligase da New England Biolabs (New England Biolabs Inc., Bervely, M, U.S.A.) e tampão da ligase (50 mM Tris- $\mathrm{HCl}$ pH 7,5, $10 \mathrm{mM} \mathrm{MgCl} 2,10 \mathrm{mM}$ ditiotreitol, $1 \mathrm{mM} \mathrm{ATP,} 25 \mu \mathrm{g} / \mathrm{mL}$ BSA), o volume foi completado para $15 \mu \mathrm{l}$ com água deionizada e após incubação a $15^{\circ} \mathrm{C}$ por $16-20$ horas, uma alíquota de $5 \mu$ foi utilizada para transformar $E$. coli $\mathrm{DH} 5 \alpha$ competentes por cloreto de cálcio. 


\subsection{SEQUENCIAMENTO DA PLP2 E PLP2a INSERIDAS NOS VETORES DE CLONAGEM}

Após a obtenção dos clones da PLP2 e da PLP2a nos vetores de expressão, estas foram submetidas ao sequenciamento utilizando-se o kit "ABI Prism ${ }^{\circ}$ Big Dye Terminator Cycle SequencingReady Reaction" da Applied Biosystems (Applied Biosystems, Foster City, CA, U.S.A.) o qual combina a AmpliTaq® DNA Polimerase, terminadores BigDye e dNTPs. Para cada reação de sequenciamento foi utilizado somente um primer, como o sequenciamento geralmente fornece uma sequência de aproximadamente $450 \mathrm{pb}$, foram utilizados os primers senso ou antisenso correspondentes ao inserto a ser sequenciado.

Seguindo as orientações do fabricante foram misturados em cada microtubo 2,0 $\mu \mathrm{l}$ de BigDye, 1,6 pmol de primer, $300 \mathrm{ng}$ de DNA plasmidial, 6,0 $\mu \mathrm{l}$ tampão Save Money (Tris $200 \mathrm{mM} \mathrm{pH} \mathrm{9,0} \mathrm{e} 5 \mathrm{mM} \mathrm{MgCl}_{2}$ ) e água Milli-Q para um volume final de $20 \mu \mathrm{l}$. Posteriormente, as reações foram colocadas no termociclador GeneAmp PCR System 2400 (Perkin-Elmer), com a seguinte ciclagem:

\begin{tabular}{|c|c|c|}
\hline \multicolumn{3}{|c|}{ CICLAGEM } \\
\hline $95^{\circ} \mathrm{C}$ & $4 \mathrm{~min}$. & \\
\hline $\begin{array}{l}96{ }^{\circ} \mathrm{C} \\
50{ }^{\circ} \mathrm{C} \\
60^{\circ} \mathrm{C}\end{array}$ & $\begin{array}{l}30 \text { seg. } \\
15 \text { seg. } \\
4 \text { min. }\end{array}$ & $40 x$ \\
\hline $4{ }^{\circ} \mathrm{C}$ & $\infty$ & \\
\hline
\end{tabular}

Ao término da reação, procedeu-se a purificação dos produtos amplificados conforme orientação do fabricante e posteriormente realizou-se a leitura do sequenciamento no sequenciador automático ABI 3100 da Applied Biosystems, utilizando eletroforese capilar.As sequências foram analisadas e alinhadas utilizando o programa DnaStar SeqMan ${ }^{T M}$ II. Esta etapa do trabalho foi realizada no Laboratório de Biotecnologia do Instituto Butantan. 


\subsection{PREPARAÇÃO DE E. coli COMPETENTE POR CLORETO DE CÁlCIO E TRANSFORMAÇÃO}

Uma colônia da bactéria $E$. coli foi inoculada em $5 \mathrm{~mL}$ de meio $2 \mathrm{YT}$, e incubada por 12 a 16 horas com agitação de $250 \mathrm{rpm}$ a $37^{\circ} \mathrm{C}$. No dia seguinte, adicionou-se $1 \mathrm{~mL}$ dessa cultura a $100 \mathrm{~mL}$ de meio $2 \mathrm{YT}$ (o volume não deve exceder mais que $15 \%$ do frasco) e incubou-se com agitação de $250 \mathrm{rpm}$ a $37^{\circ} \mathrm{C}$ até que a densidade óptica em $600 \mathrm{~nm}\left(\mathrm{DO}_{600}\right)$ estiver em torno de 0,6.

A partir desta etapa, manteve-se a cultura no gelo para estacionar a divisão celular e em seguida adicionou-se cloreto de magnésio $\left(\mathrm{MgCl}_{2}\right)$ para a concentração final de $1 \mathrm{mM}$ e deixando então em repouso por 15 minutos. Após este período dividiu-se a cultura em tubos de $50 \mathrm{~mL}$ previamente gelados e centrifugou-se a $2.300 \mathrm{~g}$ por 10 minutos a $4{ }^{\circ} \mathrm{C}$, então cada pellet foi ressuspendido em $20 \mathrm{~mL}$ de solução RFI e deixou-se em repouso por 15 minutos no gelo. Após isto, centrifugouse a $2.300 \mathrm{~g}$ por 10 minutos a $4{ }^{\circ} \mathrm{C}$ e descartou-se o sobrenadante e cada pellet foi ressuspendido com $1 \mathrm{~mL}$ de RFII e então aliquotados em volume de $50 \mu \mathrm{em}$ microtubos estéreis previamente gelados.

\begin{tabular}{|l|l|}
\hline \multicolumn{2}{|c|}{ RFI } \\
\hline Reagentes & Concentração Final \\
\hline Cloreto de Potássio & $100 \mathrm{mM}$ \\
\hline Cloreto de Manganês & $50 \mathrm{mM}$ \\
\hline Acetato de Potássio & $30 \mathrm{mM}$ \\
\hline Cloreto de Cálcio & $10 \mathrm{mM}$ \\
\hline Glicerol & $15 \%$ \\
\hline
\end{tabular}

\begin{tabular}{|l|l|}
\hline \multicolumn{2}{|c|}{ RFII } \\
\hline Reagentes & Concentração Final \\
\hline Cloreto de Potássio & $10 \mathrm{mM}$ \\
\hline Na-MOPS (pH:7,0) & $10 \mathrm{mM}$ \\
\hline Cloreto de Cálcio & $75 \mathrm{mM}$ \\
\hline Glicerol & $15 \%$ \\
\hline
\end{tabular}

Uma vez preparadas, as bactérias foram mantidas a $-80{ }^{\circ} \mathrm{C}$. Para a transformação, um microtubo contendo $50 \mu \mathrm{l}$ da bactéria competente foi descongelado em gelo por 5 minutos e adicionado em torno de $25 \mathrm{ng}$ do plasmídio de interesse. Deixou-se em gelo em repouso por 30 minutos, depois o microtubo foi 
colocado em banho Maria a $42{ }^{\circ} \mathrm{C}$ por 1 minuto e após este tempo colocado em gelo por 5 minutos.

Decorrido este tempo, adiciona-se $500 \mu \mathrm{l}$ de meio $2 \mathrm{YT}$, e levou-se a estufa a $37^{\circ} \mathrm{C}$ com $250 \mathrm{rpm}$ de agitação por 30 minutos e então $100 \mu \mathrm{l}$ dessa cultura foi adicionado à placa LB ágar com o devido antibiótico. No caso de ligação, o microtubo foi centrifugado a $3000 \mathrm{~g}$ por 3 minutos e ressuspendido em $100 \mu \mathrm{l}$ e todo este conteúdo foi adicionado à placa LB agar com antibiótico.

\subsection{EXPRESSÃO DAS PROTEÍNAS RECOMBINANTES EM E. coli}

Para os testes de expressão, foram utilizadas diferentes cepas de E. coli, (BL21(DE3)SI, BL21 Star ${ }^{\mathrm{TM}}(\mathrm{DE} 3)$ pLysS e C43(DE3) a fim de definir qual a melhor cepa para expressar a proteína recombinante.

Uma vez preparadas para competência pelo método do cloreto de cálcio como anteriormente descrito, as bactérias foram transformadas com o plasmídios de interesse como descrito no item 3.13 e semeadas em LB ágar contendo $100 \mu \mathrm{g} / \mathrm{mL}$ de ampicilina ou canamicina, dependendo da marca de seleção presente no vetor e incubadas por 16 horas, no caso das bactérias pLysS, foram adicionados $100 \mu \mathrm{g} / \mathrm{mL}$ de cloranfenicol. Depois uma colônia foi inoculada em $10 \mathrm{~mL}$ de meio LB (préinóculo) suplementado de $100 \mu \mathrm{g} / \mathrm{mL}$ de ampicilina ou canamicina ou ampicilina/canamicina no caso da bactéria pLysS, e colocadas a $37^{\circ} \mathrm{C}$ sob agitação de 250 rpm também por 16 horas.

No dia seguinte uma alíquota do pré-inóculo foi adicionada em meio LB suplementado com a mesma concentração de antibióticos (inóculo). A cultura foi incubada a $37{ }^{\circ} \mathrm{C}$ sob agitação de $250 \mathrm{rpm}$ até chegarem a fase crescente logarítmica $\left(\mathrm{DO}_{600}=0,6\right)$. Neste momento foram adicionados $1 \mathrm{mM}$ de IPTG à cultura, as amostras foram mantidas por 4 horas a $37^{\circ} \mathrm{C}$, e posteriormente centrifugadas e o pellet guardado a $-20^{\circ} \mathrm{C}$. 


\subsection{EXTRAÇÃO DE PROTEÍNAS RECOMBINANTES DE BACTÉRIAS E. coli}

O pellet obtido da expressão, foi ressuspendido em 0,1 volumes de tampão PBS ou Tris- $\mathrm{HCl} 20 \mathrm{mM} \mathrm{pH} \mathrm{8,0.} \mathrm{As} \mathrm{bactérias} \mathrm{foram} \mathrm{submetidas} \mathrm{à} \mathrm{lise} \mathrm{por} \mathrm{ultra-som}$ (sonicação). Utilizou-se uma amplitude de 70 e um pulso de 5 segundos durante 8 minutos. Os produtos sonicados foram centrifugados a $10.000 \mathrm{~g}$ por 15 minutos e o sobrenadante estocado $\mathrm{a}-20{ }^{\circ} \mathrm{C}$ até a purificação. Importante ressaltar que durante todo o procedimento, os frascos contendo as bactérias permaneceram em gelo.

\subsection{CROMATOGRAFIA DE AFINIDADE POR ÍONS METÁLICOS IMOBILIZADOS (IMAC)}

Para a purificação das proteínas recombinantes foi utilizado o método de cromatografia de afinidade por íons metálicos imobilizados (IMAC) (PORATH; OLIN, 1983). Para cada $400 \mathrm{~mL}$ de meio de cultura (expressão) utilizou-se em média $3 \mathrm{~mL}$ de resina (Talon Metal Affinity Resin - Clontech) em tubos Falcon (BD Biosciences, Canaan, CT, U.S.A.) de $15 \mathrm{~mL}$. A resina foi lavada 3 vezes com $10 \mathrm{~mL}$ do tampão de equilibrio 1X (50 mM fosfato de sódio; $300 \mathrm{mM} \mathrm{NaCl} ; \mathrm{pH}: 7,0)$. A amostra (sobrenadante do sonicado) foi aplicada na resina e incubada por pelo menos 40 minutos. Após a incubação realizou-se 4 lavagens de 10 minutos com o tampão de lavagem (50 mM fosfato de sódio; $300 \mathrm{mM} \mathrm{NaCl} ; 60 \mathrm{mM}$ de imidazol; $\mathrm{pH}$ :7,0). A proteína foi então eluída com o tampão de eluição (50 mM fosfato de sódio; 300 mM $\mathrm{NaCl} ; 500$ mM de imidazol; pH 7,0), deixando a resina incubando com este tampão por 30 minutos (foi utilizado 1,5 a $2,0 \mathrm{~mL}$ do tampão). Todo o procedimento foi realizado em tubo falcon de $15 \mathrm{~mL}$. Todas as centrifugações realizadas durante todo o processo foram de 4 minutos à $700 \mathrm{~g}$. 


\subsection{DOSAGEM DE PROTEÍNAS}

As proteínas foram dosadas pelo método de Bradford (BRADFORD, 1976). A soroalbumina bovina (BSA) foi utilizada como padrão de referência. As amostras foram diluídas 1:100, 1:50 e 1:25 e $10 \mu$ destas foram incubadas com $90 \mu \mathrm{l}$ do reagente de Bradford por 5 minutos a temperatura ambiente. Em seguida, logo após a $\mathrm{DO}_{595}$ foi medida e a concentração de proteínas calculada a partir de uma curva padrão com BSA, utilizando o programa GraphPad InStat 3.

\subsection{ELETROFORESE EM GEL DE POLIACRILAMIDA COM SDS}

As proteínas foram analisadas por eletroforese em gel de poliacrilamida na presença de SDS (LAEMMLI, 1970). As amostras contendo a mesma quantidade de bactérias lisadas com a proteína recombinante foi diluída em igual volume de tampão de amostra (350 mM de Tris/ $\mathrm{HCl} ; 10 \%$ de SDS; $30 \%$ de glicerol; $1,2 \mathrm{mg}$ de azul de bromofenol; 9,3\% de 2-mercaptoetanol) e fervidas em banho Maria por 5 minutos. O material foi então aplicado em um gel de empacotamento de $5 \%$ e gel de resolução de $12,5 \%$ de poliacrilamida e submetido à eletroforese com corrente constante de 90 volts. Os géis foram corados com azul de Coomassie R-250. Em todos os géis utilizados para as análises das proteínas recombinantes foram também adicionadas às proteínas recombinantes provenientes de culturas com ou sem indução por IPTG com a finalidade de avaliar o nível de expressão e facilitar a identificação da proteína recombinante.

\subsection{IDENTIFICAÇÃO DE PEPTÍDEOS POR ESPECTROMETRIA DE MASSAS}

A proteína SUMO/PLP2a foi submetida a análise por espectrometria de massa pelo método de peptide mass fingerprint para a dedução de sua sequência. 
Para isto, foi feita a digestão das amostras de acordo com Shevchenko et al. (1996) com modificações. Após a realização de SDS-PAGE da proteína, a banda protéica foi recortada e transferida para um tubo de 0,6 $\mathrm{mL}$. Em seguida, foram adicionados $400 \mu \mathrm{L}$ de uma solução de lavagem contendo bicarbonato de amônio 50 mM, pH 8,0 / acetonitrila (1:1) e o tubo foi agitado por 15 minutos. A solução foi descartada e o processo foi repetido até descoloração completa da banda. O gel foi reidratado com a adição de $200 \mu \mathrm{L}$ de acetonitrila por 5 minutos. A amostra foi totalmente seca por centrifugação a vácuo, reduzida com $100 \mu \mathrm{L}$ dithiothreitol $50 \mathrm{mM}$, por 30 minutos a $37{ }^{\circ} \mathrm{C}$, e incubada com $100 \mu \mathrm{L}$ de iodoacetamida $10 \mathrm{mM}$. Em seguida, foi realizada a digestão com tripsina (20 ng/ $\mu \mathrm{L}$ em bicarbonato de amônio $50 \mathrm{mM} \mathrm{pH} \mathrm{8,0)} \mathrm{por} 16 \mathrm{~h}$ a $37^{\circ} \mathrm{C}$. A amostra foi transferida para um novo tubo e os peptídeos extraídos pela adição de $30 \mu \mathrm{L}$ de uma solução contendo ácido fórmico $10 \%$ em água/acetonitrila 1:1 seguida de agitação vigorosa em vórtex por 30 minutos. Este processo foi repetido novamente, e $80 \mu \mathrm{L}$ de amostra contendo os peptídeos foram concentrados por centrifugação a vácuo e estocados a $-20{ }^{\circ} \mathrm{C}$ até análise no espectrômetro de massas. A amostra digerida foi submetida a uma coluna ProteCol C18 $15 \mathrm{~cm}$ x 300 $\mu \mathrm{m}$ (SGE) e os peptídeos eluídos foram submetidos a eletrospray em um espectrômetro LCQ Deca XP Plus ion trap (Thermo Finnigan, USA). Esta etapa foi realizada em colaboração com o Laboratório de Investigações Médicas (LIM15) da Faculdade de Medicina da Universidade de São Paulo (FMUSP).

\subsection{PRODUÇÃO DO SORO ANTI-PLP2 EM CAMUNDONGOS}

Os soros anti-SUMO/PLP2a e anti-SUMO foram obtidos pela imunização de camundongos BALB/c. Para tanto, grupos de 5 camundongos fêmeas pesando $22 \mathrm{~g}$, foram imunizados com $10 \mu \mathrm{g}$ de cada uma das proteínas adsorvidas em $100 \mu \mathrm{g}$ de hidróxido de alumínio $\left(\mathrm{Al}(\mathrm{OH})_{3}\right)$ via intraperitoneal. $\mathrm{O} \mathrm{Al}(\mathrm{OH})_{3}$ foi escolhido como adjuvante por apresentar a característica de induzir altos títulos de anticorpos, segundo Petrovsky e Aguilar (2004). Este protocolo experimental foi aprovado pelo comitê de ética animal, registro $n^{\circ} 258 / 06$. 
Antes da primeira imunização, os camundongos foram sangrados pela veia da cauda para obtenção do soro pré-imune. Doses reforço foram dadas no $7^{\circ}, 14^{\circ}$ e $21^{\circ}$ dias após a imunização inicial, com a mesma quantidade de proteína e adjuvante. No $21^{\circ}$ dia após a primeira imunização, o animal sofreu uma sangria exploratória pela veia da cauda para a quantificação do título de anticorpos realizada por ELISA (Ensaio Imunoenzimático). No $28^{\circ}$ dia foi realizada uma sangria final, sendo o soro separado por centrifugação e estocado à $-20{ }^{\circ} \mathrm{C}$ até o uso. Esta etapa foi realizada no Laboratório de Biotecnologia do Instituto Butantan.

\subsection{DETERMINAÇÃO DOS NÍVEIS DE ANTICORPOS POR ELISA}

O título de anticorpos anti-PLP2 e anti-SUMO foi determinado por ELISA como descrito por Theakston, Lloyd-Jones e Reid (1977). Assim, placa de poliestireno foi sensibilizada por 18 horas a $4{ }^{\circ} \mathrm{C}$ em câmara úmida, com $100 \mu \mathrm{l} /$ poço de uma solução contendo $10 \mu \mathrm{g} / \mathrm{mL}$ das proteínas SUMO/PLP2a e SUMO, diluído em tampão alcalino de baixa força iônica (tampão carbonato/bicarbonato 0,05 M, pH 9,6). Após este período, a placa foi submetida a 3 lavagens sucessivas de 5 minutos cada uma, com tampão de lavagem (PBS pH 7,4 contendo 0,05\% de Tween 20). A cada poço adicionou-se então, $200 \mu \mathrm{l}$ da solução bloqueadora (tampão carbonato/bicarbonato $0,05 \mathrm{M}, \mathrm{pH} 9,6$ contendo $3 \%$ de BSA). A placa foi, em seguida, incubada por 2 horas, a $37^{\circ} \mathrm{C}$, em câmara úmida. Para a titulação dos anticorpos, após um novo ciclo de lavagens, adicionou-se ao primeiro poço $200 \mu \mathrm{l}$ de soro imune de camundongo (1:4.000) diluído em tampão de incubação (PBS pH 7,4, contendo $0,05 \%$ de Tween 20 e 1\% de BSA) e seguiu-se uma diluição seriada. Como controle negativo, foi utilizado soro normal de camundongo. A placa foi então submetida à nova incubação por 1 hora a $37{ }^{\circ} \mathrm{C}$, em câmara úmida. Após 3 lavagens, a placa foi novamente incubada por 1 hora a $37^{\circ} \mathrm{C} \mathrm{com} 100 \mu \mathrm{l} /$ poço de soro anti-lgG de camundongo, marcado com peroxidase, diluído 1:1.000 em tampão de incubação. Feito mais um ciclo de lavagens, a reação foi revelada pela adição de $100 \mu \mathrm{l} /$ poço da mistura cromógena mais substrato da enzima (1 mg de OPD/mL em tampão citrato $0,2 \mathrm{M}, \mathrm{pH} 5,0$ mais $\mathrm{H}_{2} \mathrm{O}_{2} 0,06 \%$ ). A reação foi interrompida pela 
adição de $50 \mu \mathrm{l} /$ poço de $\mathrm{H}_{2} \mathrm{SO}_{4} 30 \%$. A intensidade da reação foi determinada por leitura da absorbância em leitor de placas Titertek Multiskan Plus.

\subsection{WESTERN BLOTTING}

As proteínas SUMO e SUMO/PLP2a foram submetidas à eletroforese em gel $12,5 \%$ de SDS-PAGE em duplicata (10 $\mu \mathrm{g}$ e $20 \mu \mathrm{g}$ de proteína) e eletrotransferidas em sistema semi-seco da Bio-Rad (semi-dry system, Bio-Rad Laboratories, Hercules, CA, U.S.A.) para uma membrana de nitrocelulose da Amershan (HybondECL-nitrocellulose, Amershan Biosciences, Little Chalfont, Buckinghamshire, U.K.). O tampão de transferência utilizado foi Tris-HCL 0,94 mol/L $\mathrm{pH} 8,8$; glicina 0,33 $\mathrm{mol} / \mathrm{L} ; 10 \%$ de metanol. A transferência foi realizada sob uma corrente de 0,8 $\mathrm{mA} / \mathrm{cm}^{2}$ de gel por 1 hora. Após a transferência as membranas foram coradas com Ponceau S (Sigma) para verificar a eficiência da transferência. Após a descoloração, as membranas foram incubadas por 2 horas em temperatura ambiente com solução bloqueadora (Tris/ $\mathrm{NaCl}, \mathrm{pH} 7,5$ contendo $5 \%$ de leite em pó desnatado) e então lavadas com tampão de lavagem (Tris/NaCl pH 7,5). Subsequentemente as membranas foram incubadas por 18 horas a $4{ }^{\circ} \mathrm{C}$ em tampão de incubação (Tris/ $\mathrm{NaCl}, \mathrm{pH} 7,5$ contendo $5 \%$ de leite em pó desnatado) com os soros antiSUMO/PLP2a, anti-SUMO ou pré-imune (diluição de 1:2.000). Após este período, as membranas foram submetidas a mais uma lavagem e incubadas por 2 horas com o conjugado imunoenzimático (anti-lgG de camundongo marcado com Peroxidase, marca Sigma) na diluição 1:1.000 em tampão de incubação. O excesso do conjugado foi então removido por um novo ciclo de lavagens e os componentes antigênicos foram revelados em câmara escura, utilizando a solução substrato $E C L$ Plus $^{T M}$ Western Blotting Detection System (Amersham) em filme de alta sensibilidade da mesma marca ou pela adição do cromógeno 4-cloro-1 $\alpha$-naftol 0,05\% (p/v) em Metanol 15\% (v/v) em presença de 0,03\% de $\mathrm{H}_{2} \mathrm{O}_{2}$ (v/v) diretamente na membrana. A reação foi interrompida por sucessivas lavagens com água corrente. 


\subsection{OBTENÇÃO DOS EXTRATOS TOTAIS DE CÉLULAS E TECIDOS}

Para os testes de Western Blotting com os extratos celulares de U87MG e A172 uma garrafa de cada linhagem celular de $75 \mathrm{~cm}^{3}$ (70\% confluente) foi tripsinizada, centrifugada a $1500 \mathrm{~g}$ por 5 minutos, o pellet foi ressuspendido em 200 $\mu \mathrm{L}$ de PBS e posteriormente as células foram sonicadas com uma amplitude de $50 \mathrm{e}$ pulso de 1 por 10 segundos para que essas fossem rompidas. O lisado foi então submetido à nova centrifugação a $10.000 \mathrm{~g}$ por 5 minutos e o sobrenadante foi recuperado. Para os testes de Western Blotting foi aplicado no gel de SDS-PAGE 30 $\mu \mathrm{L}$ deste extrato total de cada linhagem celular.

Para os testes com tecido humano, recebemos do Laboratório de Investigações Médicas (LIM15) da Faculdade de Medicina da Universidade de São Paulo (FMUSP) $1 \mathrm{~g}$ tanto do tecido cerebral normal quanto do tecido cerebral com GBM que haviam sido cortados em uma espessura de $10 \mu \mathrm{m}$ e separados em microtubos. Para a obtenção dos extratos totais destes tecidos foram adicionados $300 \mu \mathrm{L}$ de PBS a cada microtubo e realizados os mesmos procedimentos para a obtenção dos extratos protéicos celulares descritos acima. Este extrato protéico foi dosado por Bradford e para os testes de Western Blotting, foi aplicado $80 \mu \mathrm{g}$ de proteína tanto do tecido normal quanto do GBM.

\subsection{IMUNOHISTOQUÍMICA}

Os testes de imunohistoquímica foram realizados utilizando células U87MG e A172. As células foram fixadas em lâminas com formaldeído 3,7\% por 10 minutos ou com um fixador alcoólico $(60 \%$ de metanol, $20 \%$ de ácido acético e $10 \%$ de clorofórmio), também por 10 minutos. Após sucessivas lavagens em PBS, foram bloqueadas com solução triton $\mathrm{X}-1001 \%$, soro normal de cabra $5 \%$, BSA $0,5 \%$, glicina $0,5 \%, 0,5 \%$ gelatina de pele de peixe e incubadas por 12 horas a $4{ }^{\circ} \mathrm{C}$ com o anticorpo anti-SUMO/PLP2a. Em seguida, as lâminas foram lavadas e incubadas por duas horas à temperatura ambiente com o anticorpo anti-lgG de camundongo 
conjugado com Alexa 488 (1:100). As lâminas foram montadas com anti-fading e analisadas em microscópio confocal (LSM 510 Meta, Zeiss).

\subsection{TRANSFECÇÃO PERMANENTE DOS VETORES pEGFP-N1/PLP2 E pEGFP- C3/PLP2 EM CÉLULAS CHO}

As células $\mathrm{CHO}$ foram cultivadas em garrafas de cultura celular de $25 \mathrm{~cm}^{3} \mathrm{em}$ meio a-MEM contendo $50 \mathrm{U} / \mathrm{mL}$ de penicilina, $50 \mu \mathrm{g} / \mathrm{mL}$ de estreptomicina, $2 \mathrm{mM}$ de L-glutamina e $10 \%$ de soro fetal bovino, até atingirem a semi-confluência. Em seguida foram tripsinizadas e contadas em uma câmara de newbauer e distribuídas em uma placa de 6 poços (250.000 células por poço, equivalente a $10 \mathrm{~cm}^{3}$ ). Após 24 horas, quando as células atingiram a semi-confluência, foram realizadas as transfecções utilizando-se 1,5 $\mu \mathrm{g}$ dos plasmídios pEGFP-N1/PLP2, pEGFP-C3/PLP2 ou pEGFP-N1 como controle positivo. As transfecções foram realizadas segundo o protocolo do reagente Attractene Transfection Reagent da Qiagen (Qiagen Sciences, Maryland, U.S.A.). Após 24 horas, o meio das células foi trocado por um novo, mas desta vez, contendo $0,7 \mathrm{mg} / \mathrm{mL}$ de geneticina para selecionar somente as células transfectadas. Após 15 dias de seleção, os clones formados foram coletados com a ajuda de uma micropipeta e microscópio e colocados para crescerem em placas de 24 poços. Após atingirem uma confluência por volta de $50 \%$ os clones foram então analisados por microscopia confocal, e aqueles que apresentavam fluorescência foram mantidos e os que não apresentaram, foram descartados.

\subsection{ANÁLISE DOS CLONES POR MICROSCOPIA CONFOCAL}

Os clones selecionados como descrito no item 3.25 (positivo e controle) foram analisados mais detalhadamente para observação da distribuição da fluorescência intracelular com maior aumento em um microscópio confocal (LSM 510 Meta Zeiss). Para tanto, os clones foram plaqueados em lamínula de $25 \mathrm{~mm}$, (50.000 
células por lamínula) e deixados crescendo em placas de 6 poços (uma lamínula por placa). Após 48 horas, estas lamínulas foram colocadas em um suporte do mesmo tamanho com meio de cultura, onde a temperatura foi mantida a $37^{\circ} \mathrm{C}$ durante as observações para manter a viabilidade celular. As células foram submetidas à excitação em um comprimento de onda de $488 \mathrm{~nm}$ para a excitação da EGFP (excitação máxima da EGFP é de $507 \mathrm{~nm}$ ) e as células foram fotografadas em aumento de 40x/1.3. 


\section{RESULTADOS}

\subsection{OBTENÇÃO DA PLP2 RECOMBINANTE}

O primeiro passo deste trabalho foi a obtenção da proteína PLP2 recombinante, pela clonagem e expressão do cDNA completo obtido a partir de RNA colhido de células U87MG ou de fragmentos de cDNA obtidos por síntese.

\subsubsection{Clonagem da PLP2 no vetor PAE}

A sequência de DNA da PLP2 foi obtida nos bancos de nucleotídeos do National Center for Biotechnology Information (NCBI), conforme mostrado na figura 3. A parte codificadora produz uma proteína de 152 aminoácidos com massa molecular de aproximadamente $17 \mathrm{kDa}$, cujo ponto isoelétrico teórico é de 6,8.

Para a clonagem da PLP2 foi necessário fazer a amplificação do gene por PCR (Figura 4). Para tanto, foi utilizado como molde o cDNA oriundo de células U87MG gentilmente cedidos pela Dra. Suely Marie do Laboratório de Investigações Médicas (LIM15) da Faculdade de Medicina da Universidade de São Paulo (FMUSP). Essas células são bastante estudas e classificadas como sendo um tipo de GBM. Os procedimentos técnicos desta etapa, assim como os primers utilizados encontram-se descritos em materiais e métodos.

Pode ser observado na figura 4 que, após PCR, foi obtida a amplificação do gene da PLP2 no tamanho esperado (456 pb). Este gene foi retirado do gel de agarose e posteriormente purificado e clonado no vetor pAE (Figura 5) nos sítios de BamHI e HindIII. 
>gi|4505892|ref|NM_002668.1| Homo sapiens proteolipid protein 2(PLP2), mRNA ctgggtgtacagcgtcctcgaaaccacgagcaagtgagcagatcctccgaggcaccagggactccagcccatgcc ATGGCGGATTCTGAGCGCCTCTCGGCTCCTGGCTGCTGGGCCGCCTGCACCAA CTTCTCGCGCACTCGAAAGGGAATCCTCCTGTTTGCTGAGATTATATTATGCCTG GTGATCCTGATCTGCTTCAGTGCCTCCACACCAGGCTACTCCTCCCTGTCGGTG ATTGAGATGATCCTTGCTGCTATTTTCTTTGTTGTCTACATGTGTGACCTGCACA CCAAGATACCATTCATCAACTGGCCCTGGAGTGATTTCTTCCGAACCCTCATAG CGGCAATCCTCTACCTGATCACCTCCATTGTTGTCCTTGTTGAGAGAGGAAACC ACTCCAAAATCGTCGCAGGGGTACTGGGCCTAATCGCTACGTGCCTCTTTGGCT ATGACGCCTATGTCACCTTCCCCGTTCGGCAGCCAAGACATACAGCAGCCCCC ACTGACCCCGCAGATGGCCCGGTGTGAgcgaacttccctcatttctctctgcaatctgcaaataactc ctccattgaaataactcctccccaccccaacaacaacattcccagcagaccaactcccaccccctctttgaggtaaaa gtgcctttattgggagactttgtcttccagcctgccaatcaaccctcctgggtgtggccaccatatgtgtgtgcctaggtcc tccttctgcacgatccaataggagacaccagttctgactgaaccatgcccccacctaagtcacaaaatgagggaagt ggggagttagatttcagagtccaggccctaggttgggacccactccaaataatctcctcggtgtgggtggtggttctata gagggataaatgaataataaacattgttaaaatataaaaaaaaaaaaaaaaa

Figura 3. Sequência de DNA da PLP2 obtida nos bancos de nucleotídeos do National Center for Biotechnology Information (NCBI), a parte em azul representa a região codificadora da proteína, em vermelho estão o ATG inicial e o códon de terminação TGA.

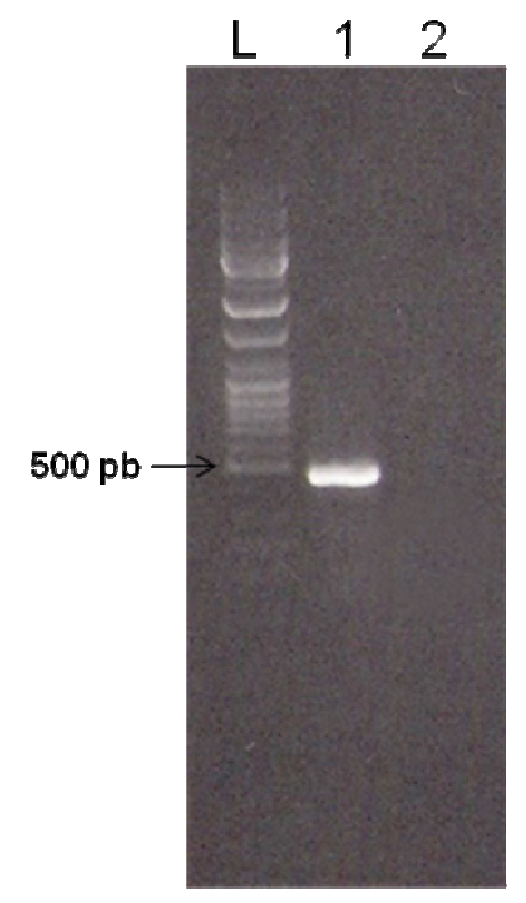

Figura 4. Gel de agarose 1\% corado com GEL-RED (New England Biosciences) mostrando a amplificação do gene codificador da PLP2. L- Marcador de massa molecular - Fermentas. 1- Gene da PLP2 amplificado (456 pb). 2- Controle negativo $\left(\mathrm{H}_{2} \mathrm{O}\right)$. 


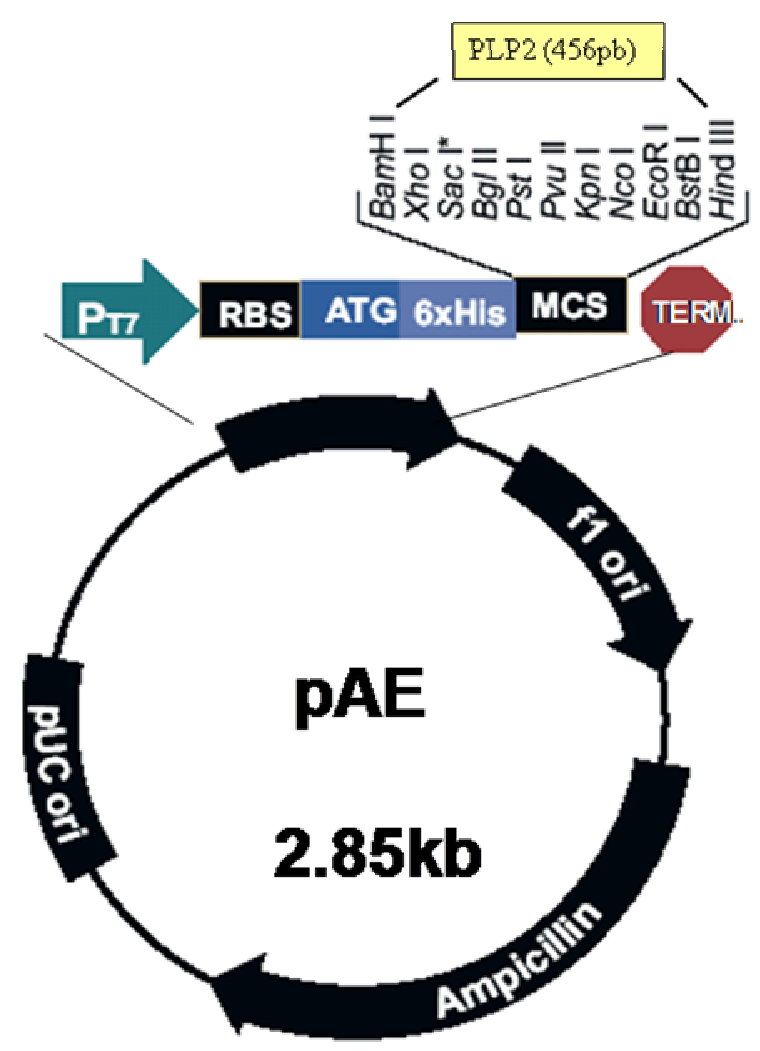

Figura 5. Figura ilustrativa do mapa do vetor PAE mostrando onde o gene da PLP2 foi clonado.

Após a clonagem, bactérias $\mathrm{DH} 5 \alpha$ foram transformadas e triadas por PCR para a confirmação da presença do inserto. Os clones positivos (Figura 6) foram submetidos à extração plasmidial para o sequenciamento completo do inserto. $O$ inserto contido no clone 1 foi sequenciado e não mostrou nenhum erro de bases, sendo selecionado para os experimentos seguintes.

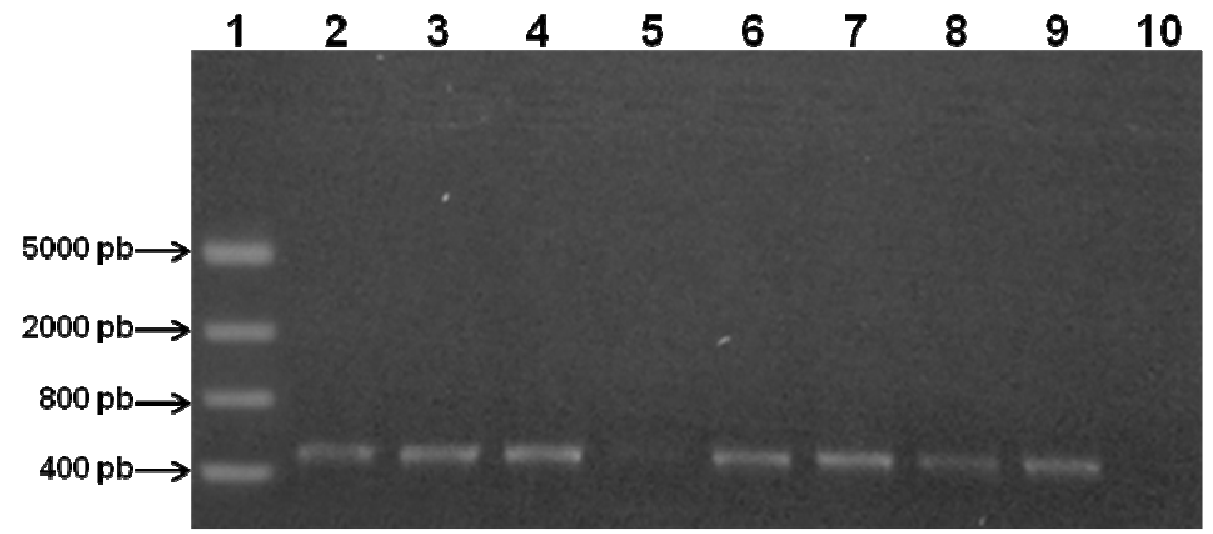

Figura 6. Gel de agarose 1\% corado com GEL-RED (New England Biosciences) mostrando seleção dos clones positivos da PLP2 clonados no vetor PAE por PCR (usando os primers senso e antisenso da PLP2). 1- Marcador de massa molecular - Fermentas. 2 a 9- Clones selecionados por PCR para PLP2. 10- Controle negativo $\left(\mathrm{H}_{2} \mathrm{O}\right)$. 


\subsubsection{Expressão da PLP2 no vetor pAE}

Após a confirmação da sequência, o vetor contendo o inserto da PLP2, foi transformado em diferentes cepas de Escherichia coli para avaliarmos qual delas seria melhor para expressá-lo. As cepas utilizadas foram BL21 (DE3) SI, BL21 (DE3) Star pLyz e C43 (DE3), induzidas por NaCl (BL21 (DE3) SI) e por IPTG (BL21 (DE3) Star pLyz e C43 (DE3) ). Todas as cepas testadas não cresceram após a transformação com o vetor contendo a PLP2, indicando que provavelmente a proteína estava sendo tóxica para as bactérias, pois após 4 horas à $37^{\circ} \mathrm{C}$ em agitação constante nenhuma das culturas apresentaram o crescimento logarítmico.

\subsubsection{Determinação das alças externas da PLP2}

A proteína PLP2 foi descrita inicialmente como uma proteína que apresenta 4 potenciais domínios transmembrânicos que se multimerizam para formar um canal iônico (BREITWIESER et al., 1997), possuindo, portanto, partes hidrofílicas e partes hidrofóbicas. Dessa forma, é possível que as partes hidrofóbicas interferiram na expressão da proteína recombinante pela bactéria. Assim, foi decidido tentar expressar somente as alças externas à membrana desta proteína, uma vez que seriam peptídeos que estariam expostos, portanto mais propensos para o reconhecimento pelos anticorpos policlonais que posteriormente iríamos produzir.

Para a determinação das alças externas da PLP2 foi utilizado o programa TMHMM Server v.2.0 (www.cbs.dtu.dk/services/TMHMM/) que prediz quais são os aminoácidos que estão localizados na parte externa da célula, na parte intramenbranar e na parte interna da célula. Este programa nos mostrou que a PLP2 possui 3 alças externas à membrana (Figura 7), a primeira com 23 aminoácidos, a segunda com 12 e a terceira com 21 aminoácidos.

Com base nestas informações, as alças foram unidas com 3 glicinas entre elas de forma a permitir maior flexibilidade (Figura 8). Esta construção foi então, 
enviada para a empresa IDT para que fosse feito o gene sintético. Esta "nova" proteína apresenta peso molecular predito de 6,54 kDa e foi chamada de PLP2a.

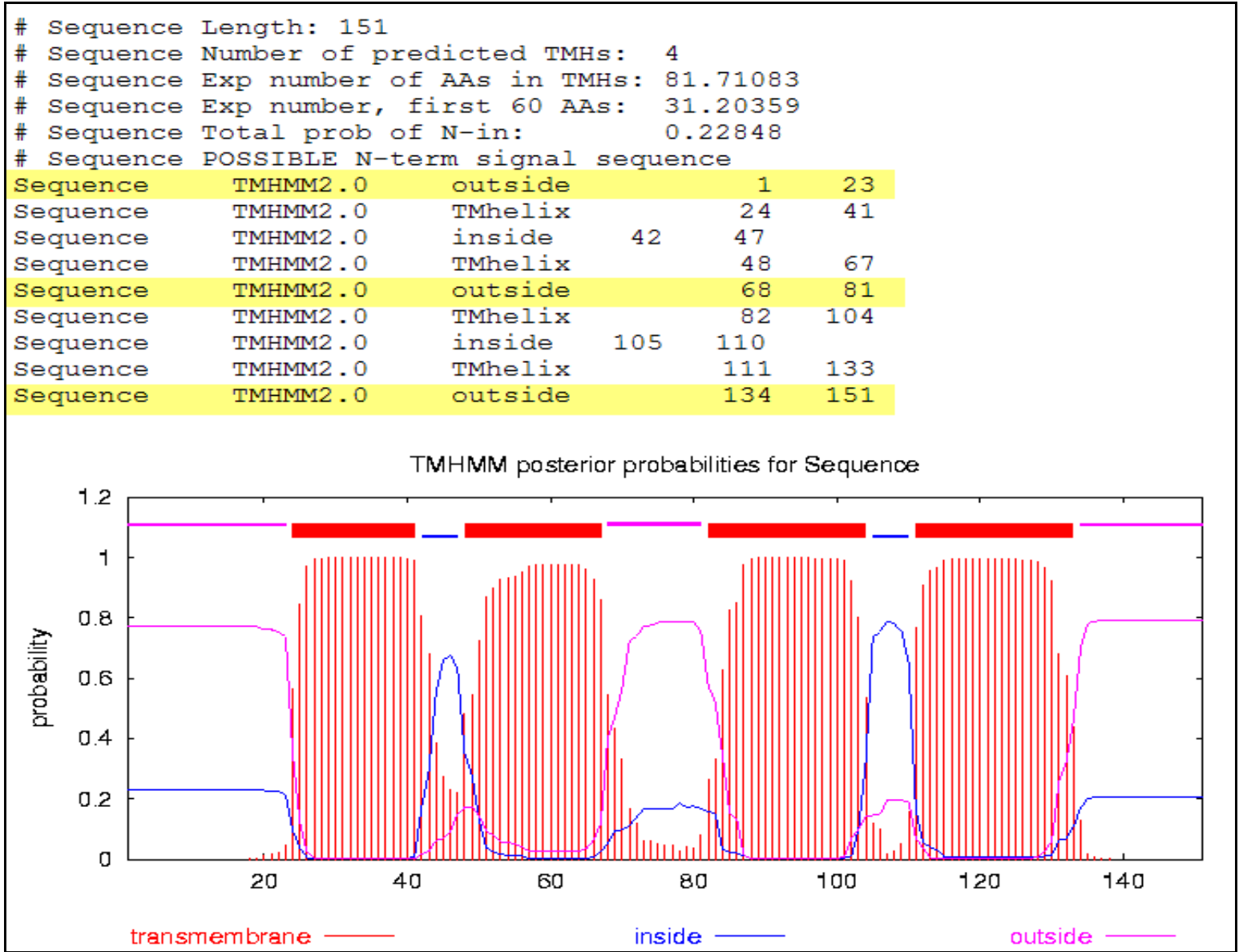

Figura 7. Gráfico gerado pelo programa TMHMM Server v.2.0 mostrando a análise de bioinformática realizada com o intuito identificar as regiões transmembranares (vermelho), internas (azul) e externas (roxo) da proteína PLP2. Esta análise revelou que a PLP2 possui 4 regiões transmembranares, 3 regiões externas e 2 regiões internas à membrana da célula.

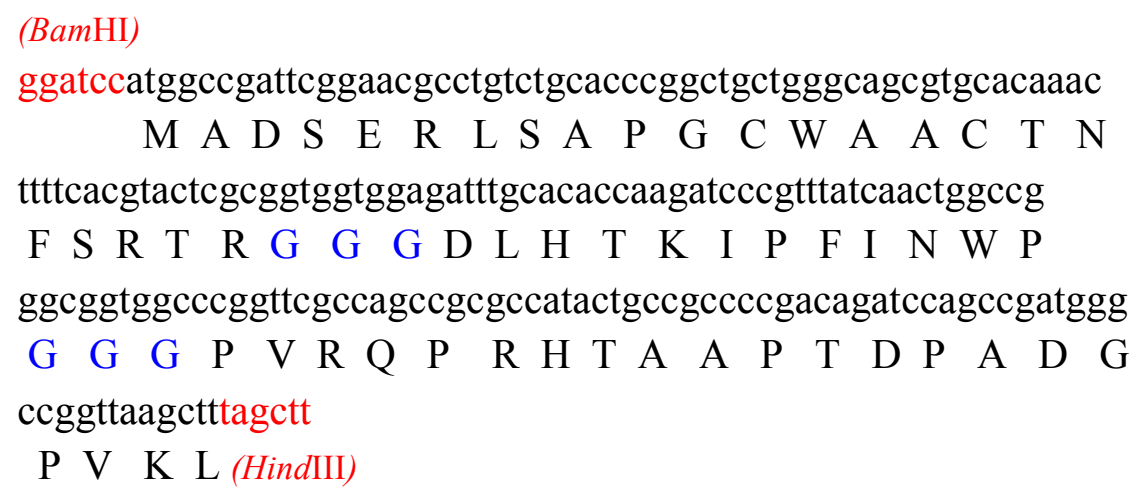

Figura 8. Esquema mostrando a sequência de nucleotídeos e aminoácidos referente ao gene sintético da proteína PLP2a. Em azul estão representadas as glicinas adicionadas para unir cada alça e em vermelho os sítios de restrição para as enzimas BamHI e HindllI, respectivamente, que foram introduzidos para efetuar as clonagens posteriores. 


\subsubsection{Clonagem e expressão da PLP2a no vetor pAE}

Para a clonagem do gene sintético correspondente as alças externas da PLP2, que denominamos PLP2a, no vetor $\mathrm{pAE}$, amplificamos esta sequência e a submetemos à digestão com as enzimas de restrição BamHI e HindllI. Após a digestão, o amplificado foi purificado e clonado no vetor pAE. Bactérias $\mathrm{DH} 5 \alpha$ foram transformadas e triadas por PCR para a confirmação da presença do inserto, como se pode observar na figura 9, apenas um clone se mostrou positivo (primeiro clone). Esse clone foi submetido à extração plasmidial e posteriormente foi feita a análise da sequência do inserto que não mostrou nenhum erro de bases. Esse clone foi selecionado para a obtenção da PLP2a.

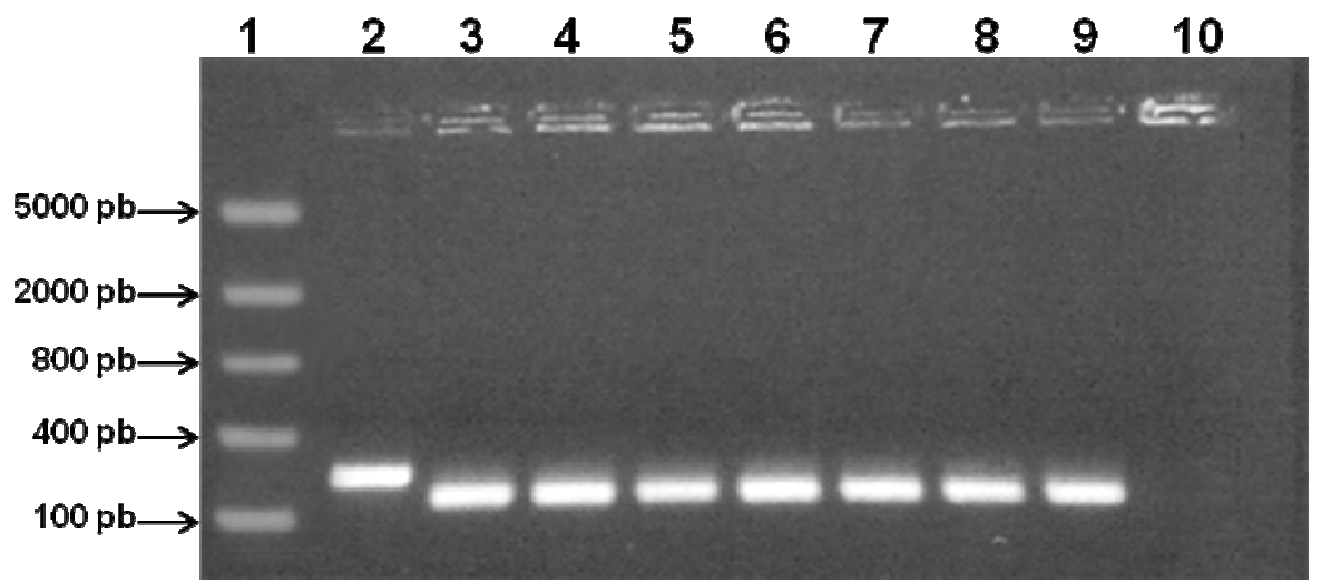

Figura 9. Gel de agarose 1,3\% corado com GEL-RED (New England Biosciences) mostrando seleção dos clones positivos da PLP2a clonados no vetor PAE por PCR (usando os primers T7 forward e T7 reverse). 1- Marcador de massa molecular - Fermentas. 2 a 9- Clones selecionados por PCR para PLP2a (somente o primeiro clone foi positivo). 10- Controle negativo $\left(\mathrm{H}_{2} \mathrm{O}\right)$.

Após o resultado do sequenciamento da PLP2a, com o intuito de verificar qual seria a melhor cepa de E. coli para a produção desta proteína foram realizados novos testes de expressão em 3 cepas diferentes como feito anteriormente. As cepas utilizadas foram BL21 (DE3) SI, BL21 (DE3) Star pLyz e C43 (DE3).

A figura 10 mostra que após os testes de expressão houve crescimento bacteriano, entretanto, não foi observada a expressão da proteína em nenhuma das cepas testadas, pois em nenhum dos extratos bacterianos foi detectada, após indução, a presença de bandas adicionais do tamanho esperado, que indicaria o aumento de expressão. 


\section{$\begin{array}{lllllll}1 & 2 & 3 & 4 & 5 & 6 & 7\end{array}$}

\section{$15 \mathrm{kDa} \longrightarrow$}

\section{$10 \mathrm{kDa} \longrightarrow$}

Figura 10. Gel de SDS-PAGE 12,5\% corado com azul de Coomassie R-250 mostrando teste de expressão da PLP2a no vetor pAE. 1- Marcador de massa molecular - Fermentas. 2Extrato bacteriano da BL21 SI não induzida. 3- Extrato bacteriano da BL21 SI induzida com 0,3M de NaCl. 4- Extrato bacteriano da BL21 Star não induzida. 5- Extrato bacteriano da BL21 Star induzida com 1mM de IPTG. 6- Extrato bacteriano da C43 não induzida. 7Extrato bacteriano da C43 induzida com 1mM de IPTG.

\subsubsection{Clonagem da PLP2a no vetor pSMT3}

Como as tentativas de expressão no vetor pAE não foram bem sucedidas, optamos por clonar a PLP2a em outro vetor. Para tanto, escolhemos o vetor pSMT3 (figura 11). Este vetor foi escolhido por permitir clonar a proteína de interesse em fusão com a proteína SUMO uma proteína que atua como chaperona, ajudando na solubilidade e dobramento correto da proteína nela fusionada. Além disso, este vetor possui um sítio de clivagem por trombina entre a SUMO e a proteína de interesse. $O$ procedimento para a clonagem do gene da PLP2a neste vetor foi o mesmo adotado na clonagem no vetor pAE, como descrito anteriormente no item 4.1.4.

Após a clonagem, bactérias $\mathrm{DH} 5 \alpha$ foram transformadas e triadas por PCR para a confirmação da presença do inserto, os clones que se mostraram positivos foram submetidos à extração plasmidial e posteriormente foi realizada a análise do 
sequenciamento dos insertos. A sequência obtida a partir do clone 1 não mostrou nenhum erro de bases, sendo esse clone selecionado para os testes de expressão.

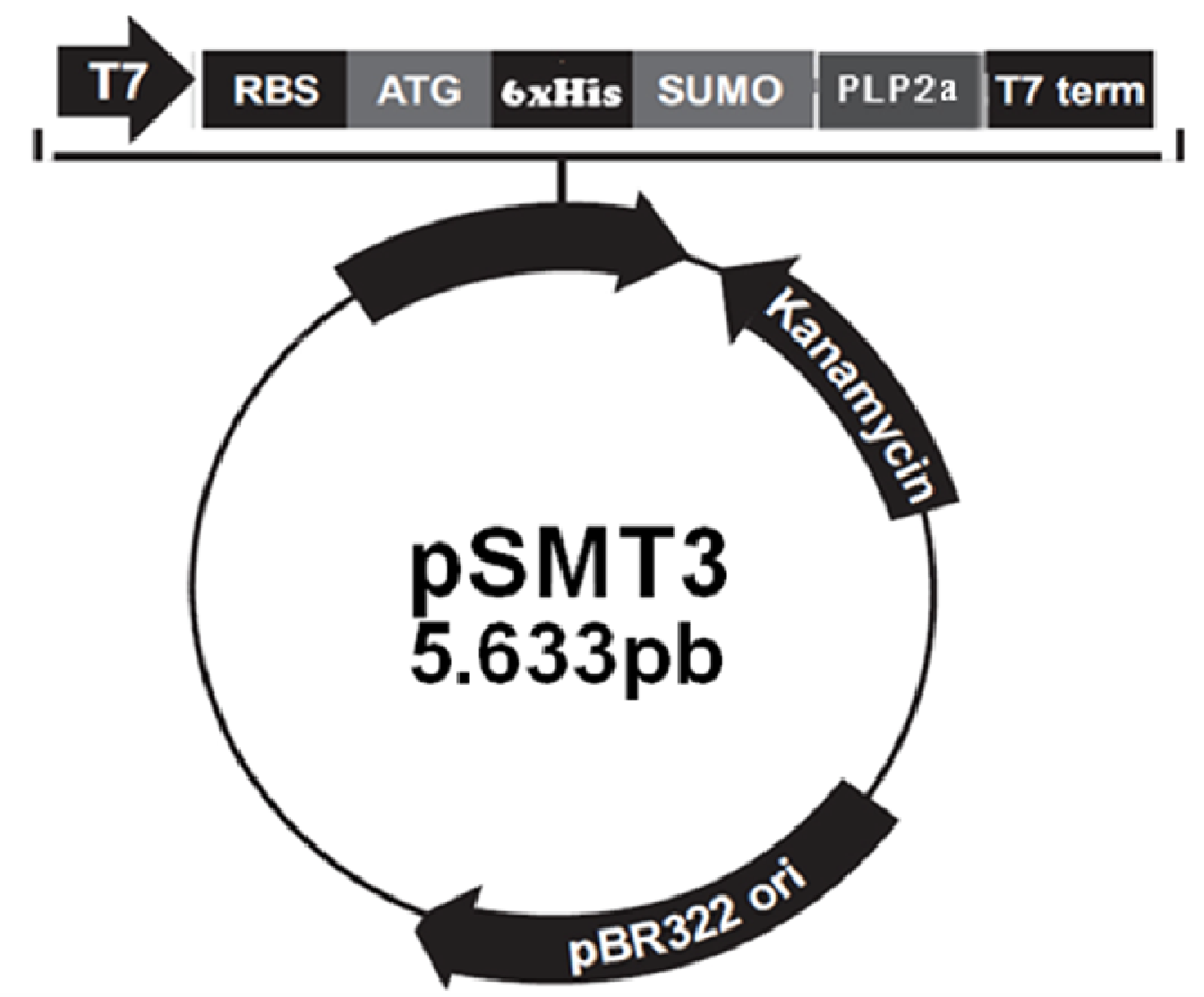

Figura 11. Figura ilustrativa do mapa do vetor PSMT3 mostrando onde o gene da PLP2a foi clonado em fusão com a proteína SUMO.

Após a clonagem do gene da PLP2a no vetor pSMT3, foi realizado um novo teste de expressão nas mesmas cepas utilizadas nos experimentos anteriores com o objetivo de identificar qual seria a melhor para futuros experimentos. Como se pode observar na figura 12, a seta indica que houve a expressão da proteína PLP2a somente na cepa C43 (DE3) induzida por 4 horas com $1 \mathrm{mM}$ de IPTG a $37^{\circ} \mathrm{C}$. Assim, ficou padronizado que esta bactéria seria utilizada nos próximos experimentos de expressão. 


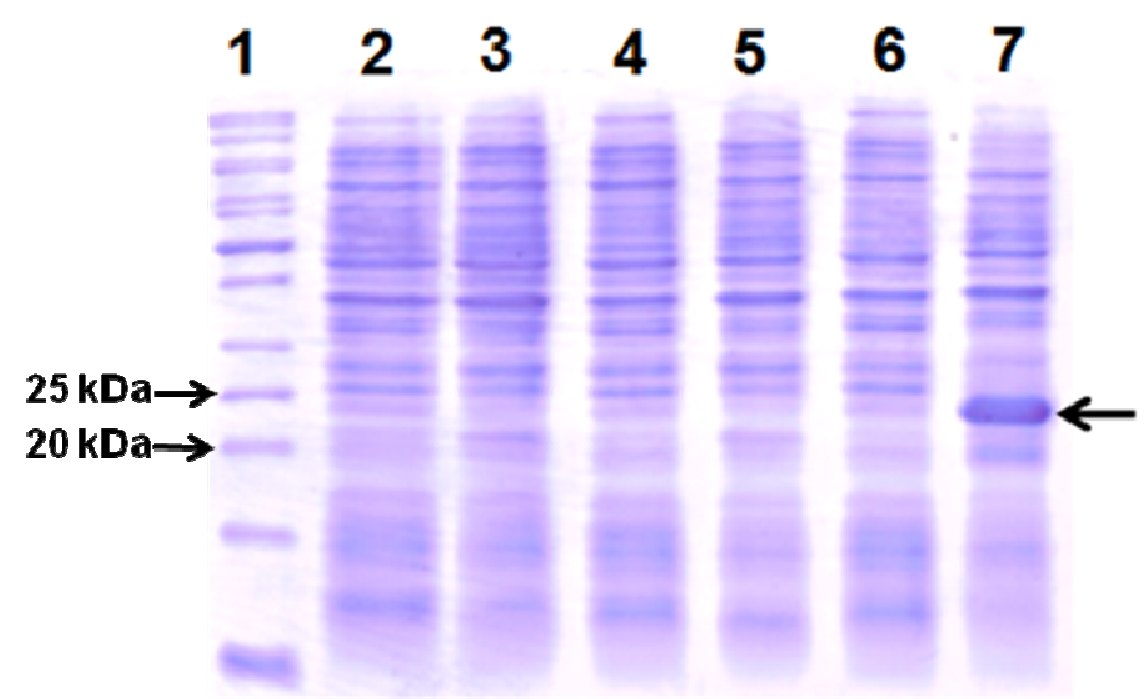

Figura 12. Gel de SDS-PAGE 12,5\% corado com azul de Coomassie R-250 mostrando teste de expressão da PLP2a no vetor pSMT3. 1- Marcador de massa molecular - Fermentas. 2Extrato bacteriano da BL21 SI não induzida. 3- Extrato bacteriano da BL21 SI induzida com 0,3M de NaCl. 4- Extrato bacteriano da BL21 Star não induzida. 5- Extrato bacteriano da BL21 Star induzida com 1mM de IPTG. 6- Extrato bacteriano da C43 não induzida. 7Extrato bacteriano da C43 induzida com $1 \mathrm{mM}$ de IPTG.

Com a nova clonagem da PLP2a no vetor pSMT3, foi denominado que a proteína recombinante passaria a se chamar SUMO/PLP2a, devido ao fato da PLP2a estar fusionada à proteína SUMO. A figura 13 mostra a sequência de aminoácidos da SUMO/PLP2a. Esta proteína possui 178 aminoácidos e tem massa molecular de 19,7 kDa, cujo ponto isoelétrico é de 5,98.

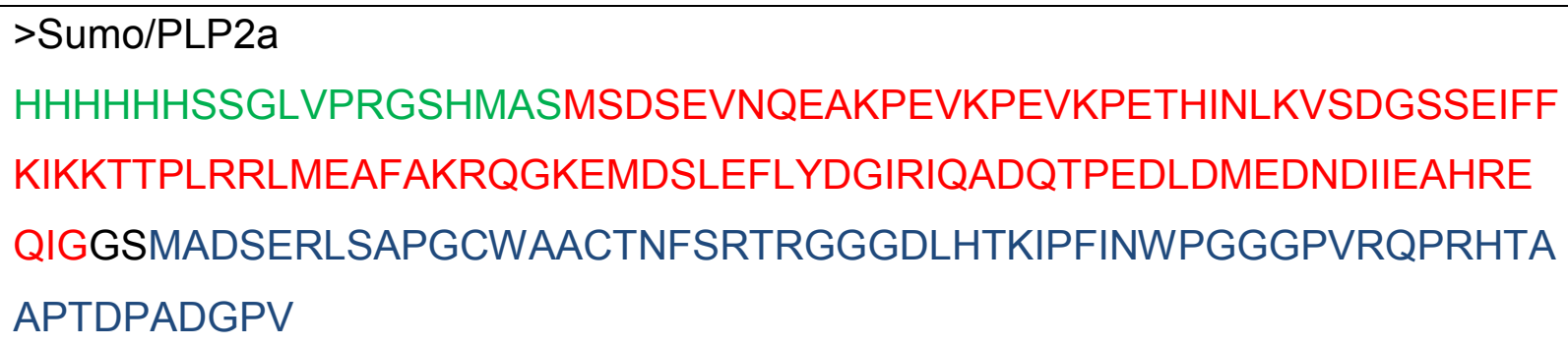

Figura 13. Sequência dos aminoácidos da proteína SUMO/PLP2a onde, a parte em verde representa a região do HIS-TAG e uma parte do vetor, em vermelho esta representada a SUMO, em preto dois aminoácidos correspondentes ao sítio de restrição de $B a m \mathrm{HI}$ e em azul a região correspondente a PLP2a.

Após a expressão da SUMO/PLP2a, foi realizado o processo de purificação da proteína recombinante por cromatografia de afinidade utilizando a resina TALON (Clontech). Esta purificação só foi possível pelo fato da proteína possuir uma região de polihistidina (HIS-TAG), pois a histidina possui afinidade a íons metálicos e a resina utilizada é carregada com íons de cobalto. Assim, durante a purificação a proteína é adsorvida a resina e posteriormente eluída por competição por outra 
espécie doadora de elétrons, no caso foi utilizado o imidazol. Os procedimentos técnicos desta etapa encontram-se descritos em materiais e métodos.

$\mathrm{Na}$ figura 14 pode-se verificar o extrato não induzido e o induzido das bactérias C43 (DE3), é possível observar a presença de uma banda mais proeminente no extrato induzido, indicando a expressão da proteína. Após purificação, foi observada a presença de uma banda com peso molecular esperado, indicando o sucesso da produção e purificação da proteína recombinante.

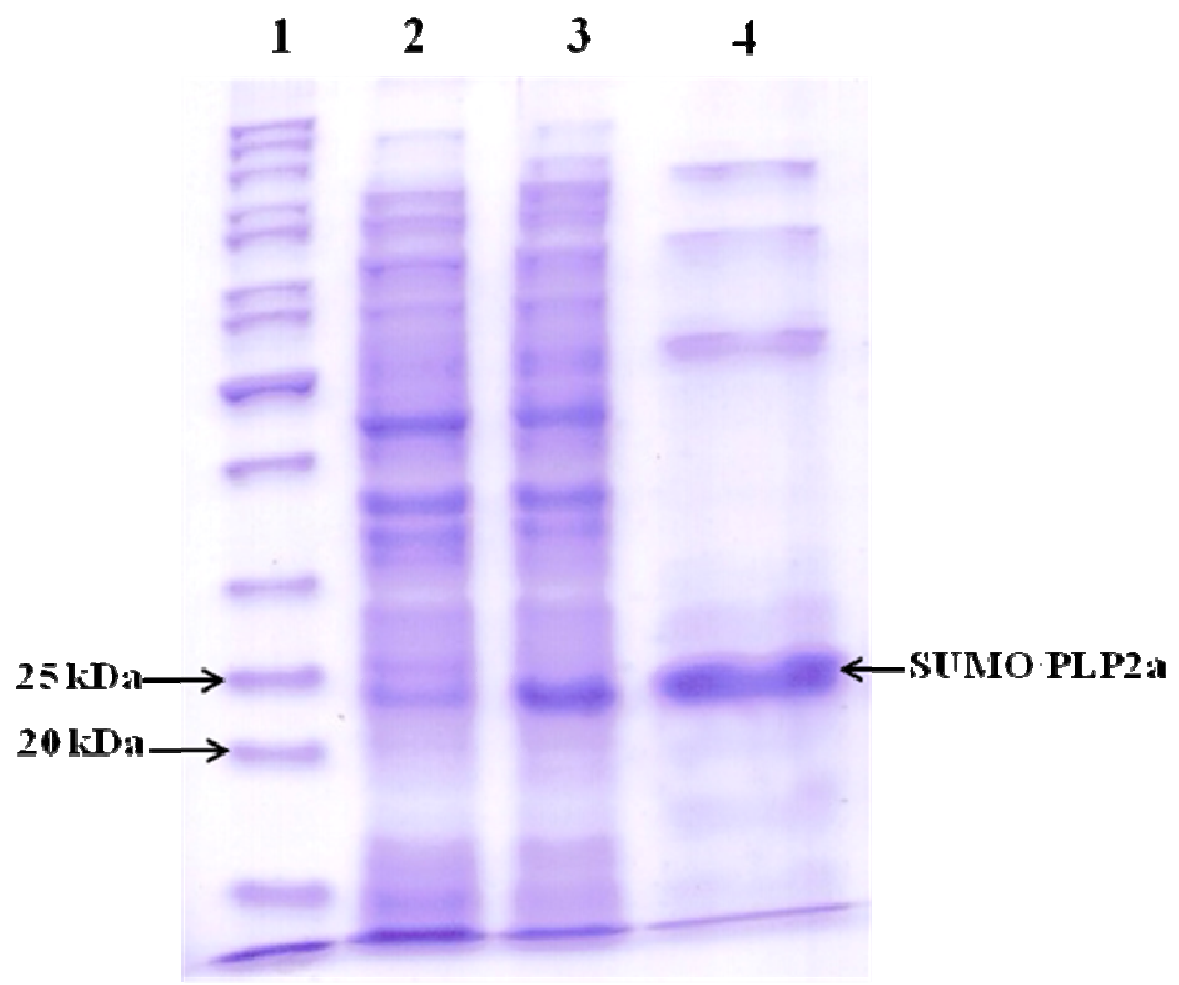

Figura 14. Gel de SDS-PAGE 12,5\% corado com azul de Coomassie R-250 mostrando expressão e purificação da proteína SUMO/PLP2a. 1- Marcador de massa molecular - Fermentas. 2Extrato bacteriano da C43 não induzida. 3- Extrato bacteriano da C43 induzida com 1mM de IPTG. 4- SUMO/PLP2a purificada.

\subsubsection{Expressão da proteína SUMO}

Com a expressão da proteína SUMO/PLP2a, já era possível dar inicio às imunizações para a obtenção dos anticorpos policlonais mesmo sem clivar a SUMO da PLP2a, pois a SUMO pode funcionar como uma proteína carreadora aumentando assim, a imunogenicidade já que a PLP2a é muito pequena. Porém, para dar início aos protocolos de obtenção dos anticorpos anti-SUMO/PLP2a foi preciso expressar 
a proteína SUMO para que ela fosse usada também na imunização dos camundongos e obtenção de soro policlonal utilizado como controle nos experimentos futuros.

Para a expressão da SUMO, bactérias C43 (DE3) foram transformadas utilizando o vetor pSMT3 "vazio". Após as bactérias atingirem seu crescimento logarítmico, foi adicionado o IPTG em uma concentração de $1 \mathrm{mM}$ para induzir a expressão da SUMO. Feita a expressão, a SUMO foi purificada seguindo o mesmo protocolo de purificação da SUMO/PLP2a. Na figura 15 é possível observar através de um gel de SDS-PAGE a expressão e purificação da SUMO e da SUMO/PLP2a.

As proteínas purificadas, a partir de um inóculo inicial de $250 \mathrm{~mL}$ de meio de cultura, foram dosadas pelo método de Bradford, apresentando uma concentração de $841 \mu \mathrm{g} / \mathrm{mL}$ para a SUMO/PLP2a e de $510 \mu \mathrm{g} / \mathrm{mL}$ para a SUMO.

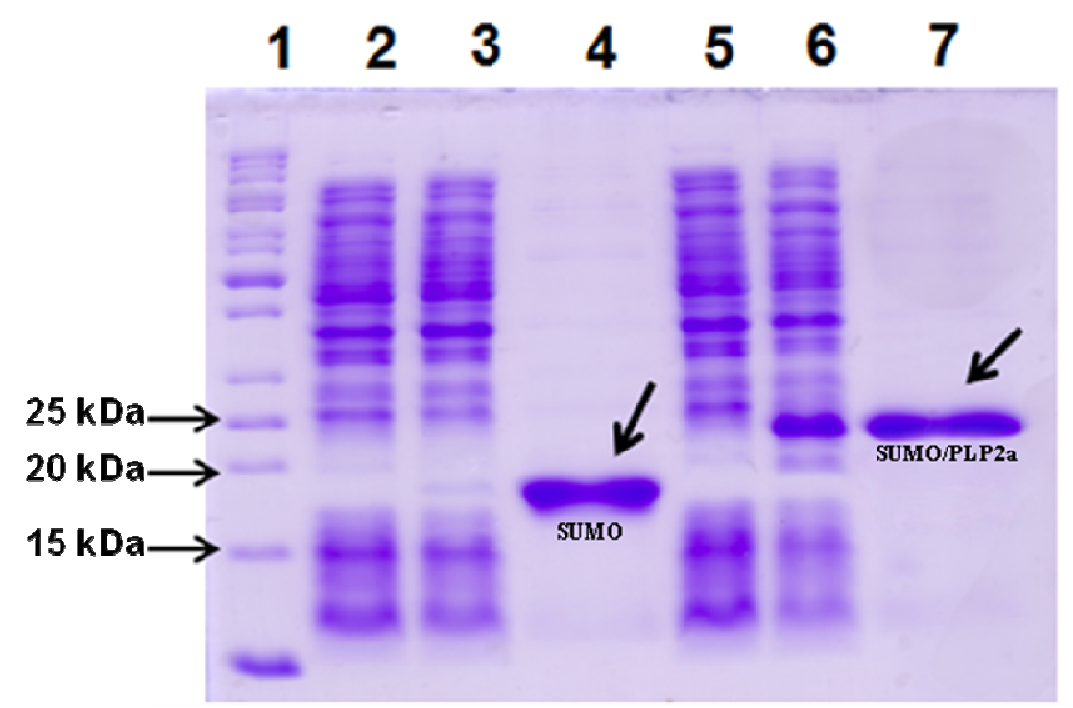

Figura 15. Gel de SDS-PAGE 12,5\% corado com azul de Coomassie R-250 mostrando expressão e purificação das proteínas SUMO e SUMO/PLP2a. 1- Marcador de massa molecular Fermentas. 2- Extrato bacteriano da C43 não induzida (SUMO). 3- Extrato bacteriano da C43 induzida com $1 \mathrm{mM}$ de IPTG (SUMO). 4- SUMO purificada. 5- Extrato bacteriano da C43 não induzida (SUMO/PLP2a). 6- Extrato bacteriano da C43 induzida com $1 \mathrm{mM}$ de IPTG (SUMO/PLP2a). 7- SUMO/PLP2a purificada. 


\subsubsection{Identificação de peptídeos da proteína SUMO/PLP2a por espectrometria de massas}

Como a proteína SUMO/PLP2a seria utilizada para produção de anticorpos foi decidido fazer o sequenciamento desta proteína para verificar se as alças correspondentes a PLP2 realmente foram expressas. Para tanto, a proteína foi analisada por espectrometria de massas pelo de método de peptide mass fingerprint (impressão digital da massa do peptídeo). Para a dedução de sua sequência, foram determinadas as massas dos peptídeos gerados pela digestão tríptica tanto da proteína em solução quanto da proteína recortada e extraída do gel de SDS-PAGE 12,5\%. A tabela 2 mostra os peptídeos encontrados, na proteína SUMO/PLP2a extraída do gel e em solução.

TABELA 2- Peptídeos encontrados por espectrometria de massas

Proteína

Proteína extraída do gel
Sequência dos peptídeos encontrados GSSHHHHHHSSGLVPR VSDGSSEIFFK IQADQTPEDLDMEDNDIIEAHR IPFINWPGGGPVR

\section{GSSHHHHHHSSGLVPR}

Proteína em solução

VSDGSSEIFFK

EQIGGSMADSER

$\mathrm{Na}$ figura 16 é possível verificar a sequência completa de aminoácidos da proteína SUMO/PLP2a, onde em negrito estão representados os peptídeos que foram encontrados na espectrometria de massa. Podemos observar que foi encontrado o início da proteína onde está localizada a cauda de polihistidina, uma porção intermediária e o final da proteína SUMO e foi encontrado também o início da primeira alça, o final da segunda alça e o início da terceira alça correspondentes a proteína PLP2a. Com este resultado foi possível dar inicio a produção dos anticorpos contra a proteína SUMO/PLP2a. 
GSSHHHHHHSSGLVPRGSHMASMSDSEVNQEAKPEVKPEVKPETHINLKVSDGSS EIFFKIKKTTPLRRLMEAFAKRQGKEMDSLEFLYDGIRIQADQTPEDLDMEDNDIIEA HREQIGGSMADSERLSAPGCWAACTNFSRTRGGGDLHTKIPFINWPGGGPVRQPR HTAAPTDPADGPV

Figura 16. Figura representando a sequência de aminoácidos da proteína SUMO/PLP2a, onde em negrito estão representados os peptídeos encontrados por espectrometria de massas.

\subsection{PRODUÇÃO DE ANTICORPOS POLICLONAIS CONTRA A PROTEÍNA RECOMBINANTE EM CAMUNDONGO}

Com a intenção de produzir anticorpos policlonais contra as proteínas recombinantes, foi feita imunização em camundongos. Foram utilizados dois grupos diferentes (5 camundongos por grupo), um grupo imunizado com a SUMO e outro grupo imunizado com a SUMO/PLP2a. Foram utilizados $10 \mu \mathrm{g}$ da proteína (antígeno) homogeneizados com $100 \mu \mathrm{g}$ de $\mathrm{Al}(\mathrm{OH})_{3}$ (hidróxido de alumínio), esta mistura foi então injetada via intraperitoneal em camundongos BALB/c.

Após a terceira imunização foi feita uma sangria exploratória para avaliar a resposta imune de cada grupo e após a quarta imunização foi realizada a sangria final dos camundongos. $\mathrm{O}$ título de anticorpos dos soros obtidos foi determinado por ELISA usando como coating as proteínas recombinantes SUMO e SUMO/PLP2a. A figura 18 mostra que o título destes anticorpos produzidos em camundongos foi de mais de 20.480, mostrando assim que os camundongos tiveram uma boa resposta imune contra as duas proteínas e a produção dos anticorpos foi obtida com sucesso.

Posteriormente, foi avaliada a capacidade destes soros em reconhecer as proteínas recombinantes SUMO e SUMO/PLP2a utilizando-se da metodologia de western blotting. Na figura 18 podemos verificar que os soros anti-SUMO/PLP2a (Figura 18A) e anti-SUMO (Figura 18C) reconheceram as proteínas recombinantes (indicado pelas setas), enquanto que os soros pré-imunes não reconheceram nenhuma banda (Figuras 18B e 18D), mostrando mais uma vez o sucesso obtido na produção destes anticorpos contra as proteínas recombinantes. 

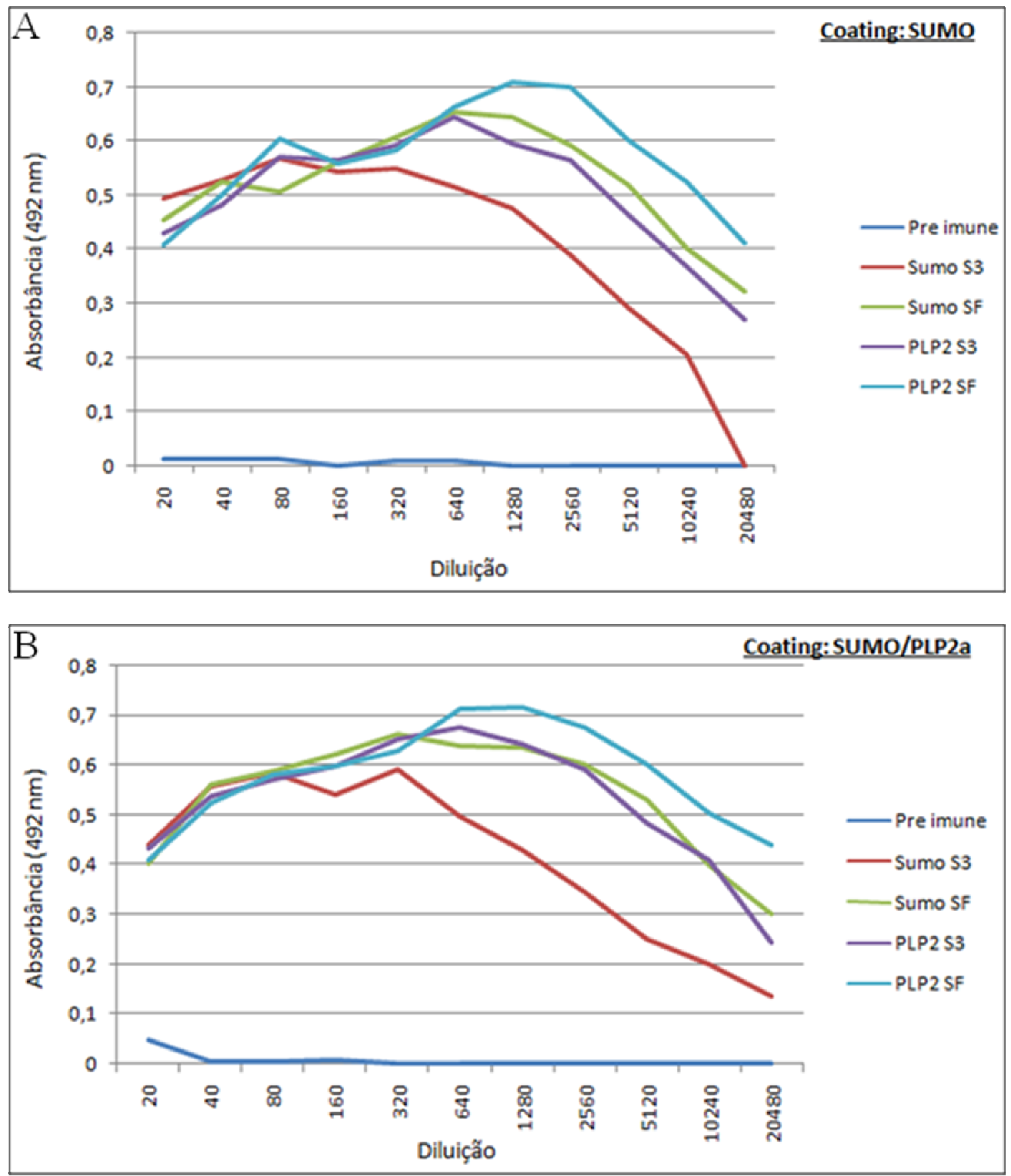

Figura 17. Produção de anticorpos anti-PLP2a ou anti-SUMO em soros de camundongos BALB/c previamente imunizados. A produção de anticorpos foi avaliada nos seguintes soros: préimune, anti-SUMO obtido na terceira sangria pós-imunização (Sumo S3), anti-SUMO sangria final (Sumo SF), anti-SUMO/PLP2a terceira sangria pós-imunização (PLP2 S3) e anti-SUMO/PLP2a sangria final (PLP2 SF). A) ELISA utilizando como coating a proteína SUMO. B) ELISA utilizando como coating a proteína SUMO/PLP2a. Os resultados foram expressos em absorbância obtida nas diferentes diluições dos soros. 

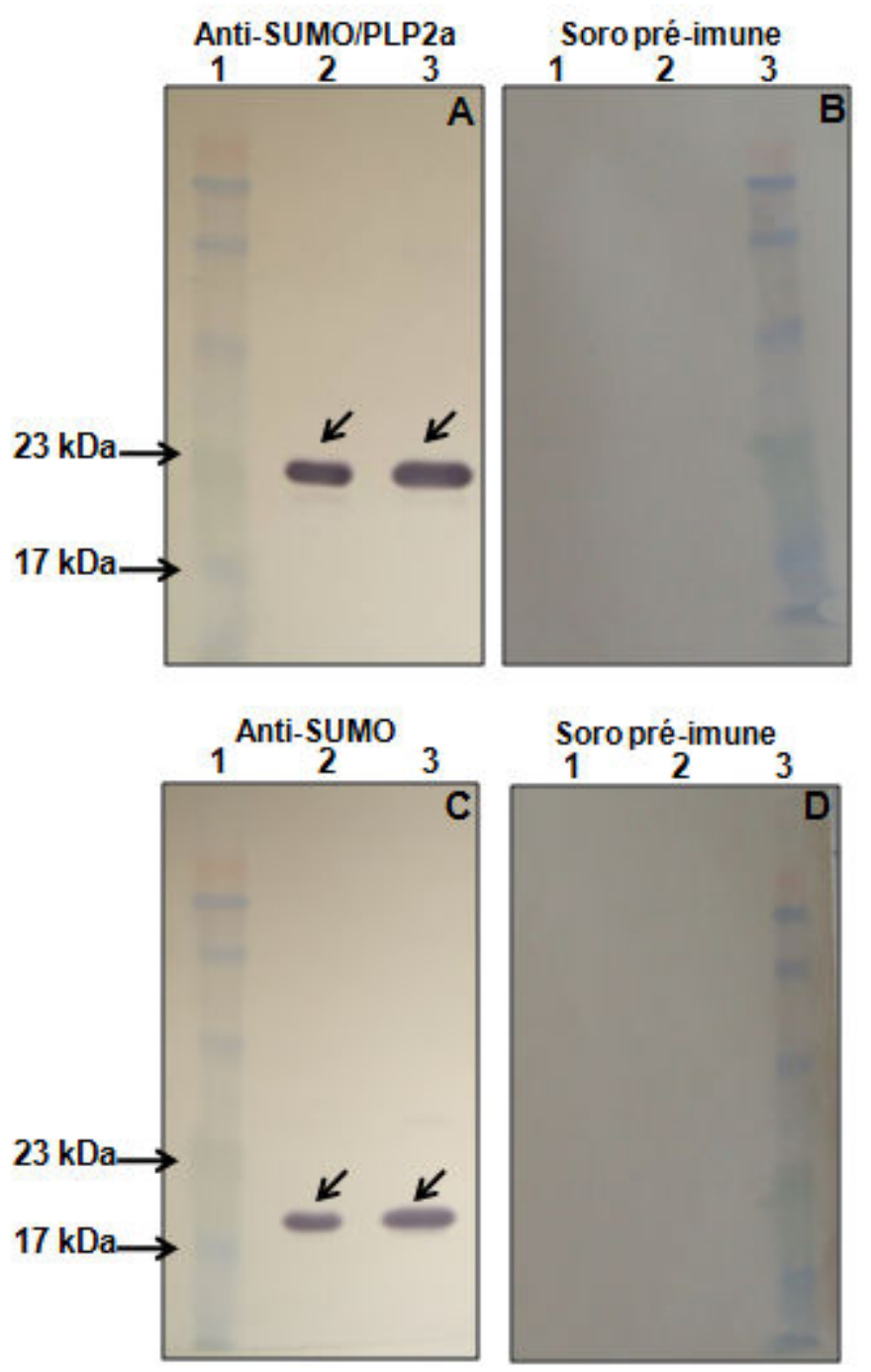

Figura 18. Western Blotting para avaliar a especificidade dos soros anti-SUMO/PLP2a e anti-SUMO. A) 1- Marcador de massa molecular - New England Biolabs; 2- $10 \mu \mathrm{g}$ de SUMO/PLP2a; 3$20 \mu \mathrm{g}$ de SUMO/PLP2a. B) 1- $10 \mu \mathrm{g}$ de SUMO/PLP2a; 2- $20 \mu \mathrm{g}$ de SUMO/PLP2a; 3Marcador de massa molecular - New England Biolabs. C) 1- Marcador de massa molecular - New England Biolabs; 2- $10 \mu \mathrm{g}$ de SUMO; 3- $20 \mu \mathrm{g}$ de SUMO. D) 1- $10 \mu \mathrm{g}$ de SUMO/PLP2a; 2- 20 mg de SUMO/PLP2a; 3- Marcador de massa molecular - New England Biolabs.

\subsection{DETECÇÃO DA PLP2 EM GLIOBLASTOMA HUMANO}

O próximo passo deste trabalho foi utilizar os anticorpos produzidos anteriormente, como uma ferramenta para a detecção da PLP2 em glioblastomas humanos através da metodologia de western blotting, para que assim possa ser confirmada sua alta expressão neste tipo de tumor. 


\subsubsection{Análise da especificidade do soro anti-SUMO/PLP2a contra a PLP2 nativa}

Antes de detectar a PLP2 em tecido de glioblastoma e tecido normal, foi decidido realizar um western blotting utilizando os soros anti-SUMO/PLP2a e antiSUMO contra os extratos totais de células das linhagens de A172 e U87MG. Estas células foram escolhidas por serem uma linhagem celular bastante estudada de glioblastomas e estudos de PCR em tempo real realizados anteriormente por nosso grupo, mostram que estas células possuem alta expressão gênica da PLP2.

O resultado deste experimento mostrou que o soro anti-SUMO/PLP2a foi capaz de reconhecer nas duas linhagens, uma proteína na altura de $17 \mathrm{kDa}$, que corresponde a massa molecular esperada para a PLP2 nativa. O soro anti-SUMO não reconhece nenhuma banda específica em nenhuma das linhagens (figura 19). Com estes resultados é possível confirmar que o soro anti-SUMO/PLP2a é capaz de reconhecer a proteína PLP2 nativa por western blotting, enquanto o soro anti-SUMO não reconheceu nenhuma proteína. Confirmando assim, a especificidade do soro anti-SUMO/PLP2a contra a PLP2.

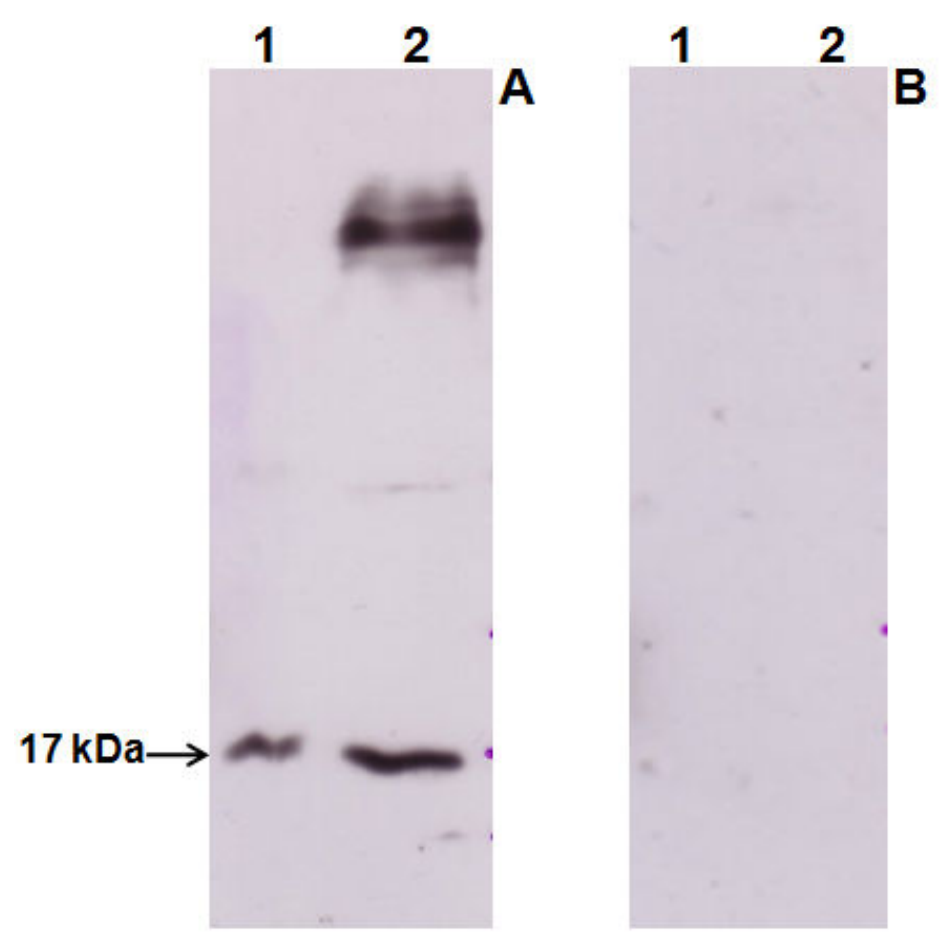

Figura 19. Western Blotting analisando a especificidade dos soros anti-SUMO/PLP2a e anti-SUMO. A) Anti-SUMO/PLP2a - 1- Linhagem U87MG; 2- Linhagem A172. A seta indica um reconhecimento de uma banda na altura de 17. B) Anti-SUMO - 1- Linhagem U87MG; 2Linhagem A172. 


\subsubsection{Detecção da PLP2 em tecido de glioblastoma humano}

Com a intenção de provar que a PLP2 está sendo altamente expressa em tecidos tumorais quando comparados com tecidos normais resolvemos fazer mais um experimento de western blotting. Desta vez foi utilizado o soro anti-SUMO/PLP2a frente a tecido tumoral de GBM humano e tecido cerebral humano normal. Como inicialmente o soro foi capaz de reconhecer a PLP2 no extrato celular das células U87MG foi decidido utilizar este extrato celular como um controle positivo da reação. $\mathrm{Na}$ figura 20B é possível observar que o soro anti-SUMO/PLP2a foi capaz de reconhecer uma banda na altura de $17 \mathrm{kDa}$ (mesma massa molecular da PLP2) no tecido tumoral e no extrato celular de células U87MG (indicado pelas setas) e não reconheceu nada específico no tecido normal, isso mostra que a PLP2 realmente esta sendo altamente expressa nos glioblastomas quando comparado com tecido normal. A figura 20A mostra a membrana de nitrocelulose corada com Ponceau S, indicando a homogeneidade na transferência das proteínas.

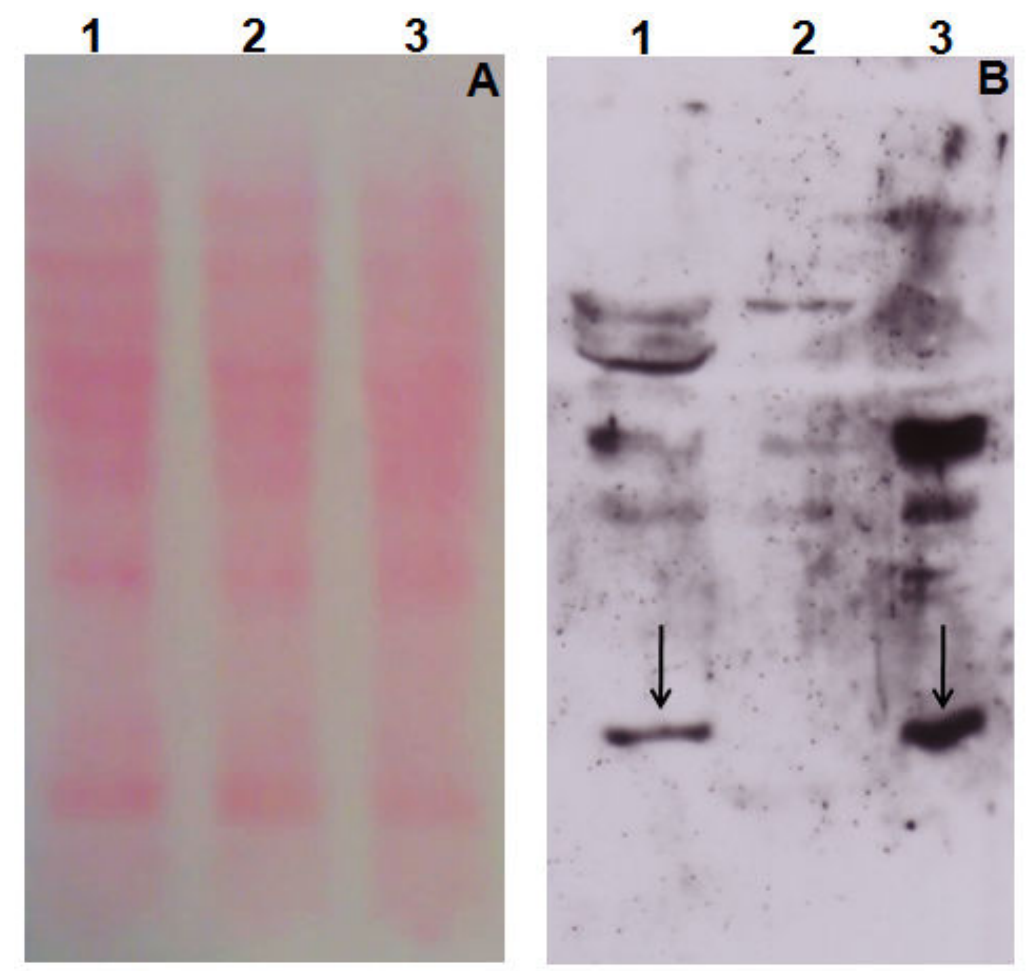

Figura 20. Western Blotting utilizando os anticorpos anti-SUMO/PLP2a frente a tecido tumoral de GBM humano (1); tecido cerebral humano normal (2) e ao extrato celular da linhagem U87MG (3). A) Membrana de nitrocelulose corada com ponceau S (Sigma) após eletrotransferência mostrando a eficiência da transferência dos extratos totais utilizados neste experimento. B) As setas indicam o reconhecimento pelo soro anti-SUMO/PLP2a de uma banda na região esperada para a PLP2 nativa. 


\subsection{IDENTIFICAÇÃO DA LOCALIZAÇÃO CELULAR DA PLP2}

Com a intenção de identificar a localização celular da PLP2, foi decidido utilizar o soro anti-SUMO/PLP2a em testes de imunohistoquímica em células U87MG e A172. Entretanto, estes testes não forneceram resultados suficientes que permitissem determinar a localização celular da PLP2. Com isto, foi decidido estudar sua localização expressando-a em células de mamífero.

\subsubsection{Clonagem da PLP2 nos vetores pEGFP-N1 e pEGFP-C3}

Para identificar a localização celular da PLP2, foi decidido expressá-la em células de mamífero fusionando-a com a proteína EGFP, pois esta proteína emite fluorescência quando excitada a $488 \mathrm{~nm}$ tornando possível visualizar sua localização celular por microscopia confocal. Para isto, o gene da PLP2 foi clonado nos vetores pEGFP-N1 e pEGFP-C3. A figura 21 mostra os mapas destes dois vetores.
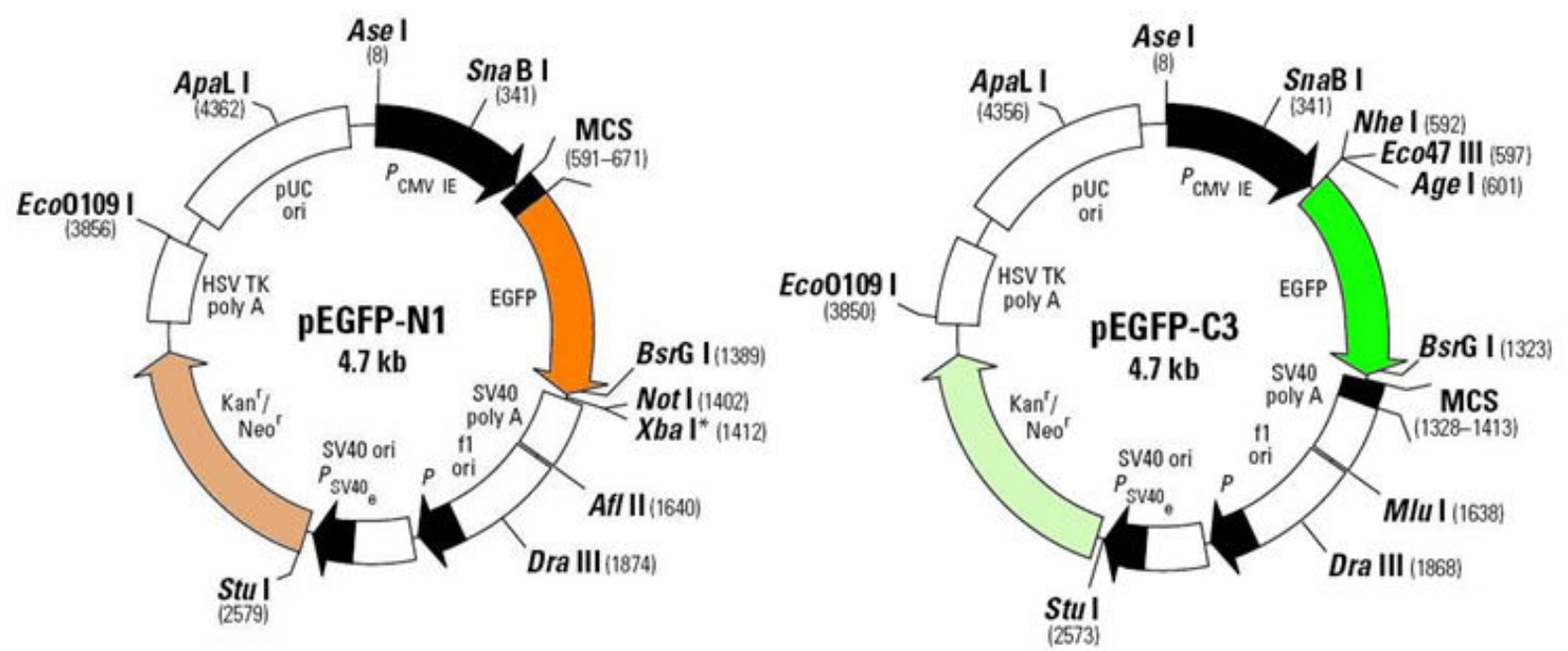

Figura 21. Mapa dos vetores para expressão de proteína em células de mamífero pEGFP-N1 e pEGFP-C3 (Clontech) utilizados para clonagem do gene da PLP2 fusionada com a proteína EGFP em sua porção N-terminal e C-terminal respectivamente.

Para a clonagem da PLP2, desta vez a sequência completa desta proteína, foram desenhados novos primers com sítios para as enzimas de restrição Hindlll e BamHI (ver item 3.8) e feita uma nova amplificação do gene por PCR. Este gene foi purificado, submetido à digestão com as enzimas de restrição juntamente com os 
vetores e posteriormente clonado nos vetores pEGFP-N1 e pEGFP-C3. Após a clonagem, bactérias $\mathrm{DH} 5 \alpha$ foram transformadas e triadas por PCR para a confirmação da presença do inserto. Os clones positivos foram submetidos à extração plasmidial e posteriormente foi feita a análise do sequenciamento destes clones. O clone 2 do vetor pEGFP-N1 e o clone 1 do vetor pEGFP-C3 não mostraram nenhum erro de bases.

\subsubsection{Transfecção permanente em células $\mathrm{CHO}$}

Confirmada a clonagem do gene da PLP2, foi realizada a transfecção permanente dos clones em células $\mathrm{CHO}$. A transfecção foi realizada utilizando os vetores pEGFP-N1 e pEGFP-C3 com o gene da PLP2 clonados (pEGFP-N1/PLP2 e pEGFP-C3/PLP2) e como controle foi utilizado o vetor pEGFP-N1 vazio para que este expressasse somente a EGFP. A transfecção foi realizada com o reagente Attractene Transfection Reagent (Qiagen) como mostrado em materiais e métodos.

Devido à presença do gene de resistência a neomicina nos vetores, as células que foram transfectadas se tornam resistentes a droga geneticina, enquanto as que não receberam os vetores morrem. Após 15 dias em média, ocorre à formação de pequenos clones, que posteriormente foram coletados com a ajuda de uma micropipeta. Os clones selecionados foram analisados por microscopia confocal com filtro apropriado para EGFP para verificar se eles estavam expressando ou não à proteína.

Na figura 22 é possível observar a expressão das proteínas nos clones selecionados mostrando assim que a transfecção foi bem sucedida. Para os próximos experimentos, com o intuito de verificar com melhor aumento a localização celular desta proteína foi decidido usar somente as células transfectadas com pEGFP-N1/PLP2, pois nestas, o padrão de distribuição da PLP2 indicava sua presença na membrana celular.

Realizamos também a transfecção em células U87MG, contudo, o número de clones foi extremamente baixo (três clones), e estes, quando observados no microscópio confocal não apresentaram fluorescência, provavelmente só contendo a 
marca de seleção, indicando um provável silenciamento gênico da EGFP/PLP2 (dados não mostrados).

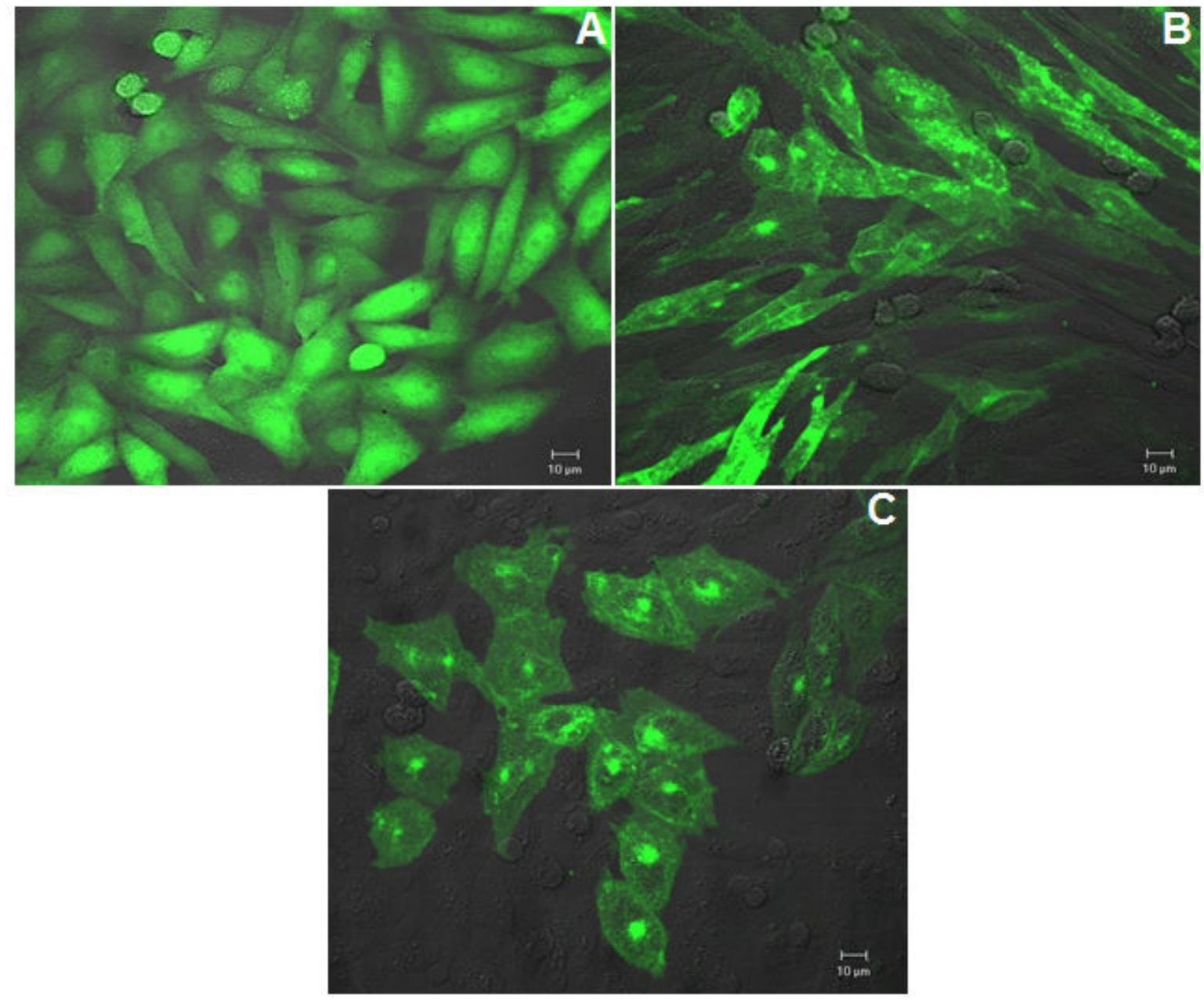

Figura 22. Análise dos clones selecionados por microscopia confocal (aumento de 40x/0.6). A) Células $\mathrm{CHO}$ transfectadas com pEGFP-N1 vazio. B) Células $\mathrm{CHO}$ transfectadas com pEGFP-N1/PLP2. C) Células CHO transfectadas com pEGFP-C3/PLP2.

Com a intenção de verificar a localização celular da PLP2 foi realizada a análise dos clones transfectados com a PLP2 fusionada com a EGFP por microscopia confocal com aumentos maiores a fim de verificar se realmente esta proteína se direciona para a membrana celular.

Com a realização deste experimento foi possível visualizar a localização celular da PLP2. A figura 23A mostra as células analisadas com maior aumento (40x/1.3). Nesta figura as setas indicam a localização da PLP2 fusionada com a EGFP na membrana plasmática e as cabeças de setas indicam a localização na região perinuclear, onde ela pode estar concentrada no complexo de Golgi e/ou retículo endoplasmático para depois ser exportada para a membrana. 


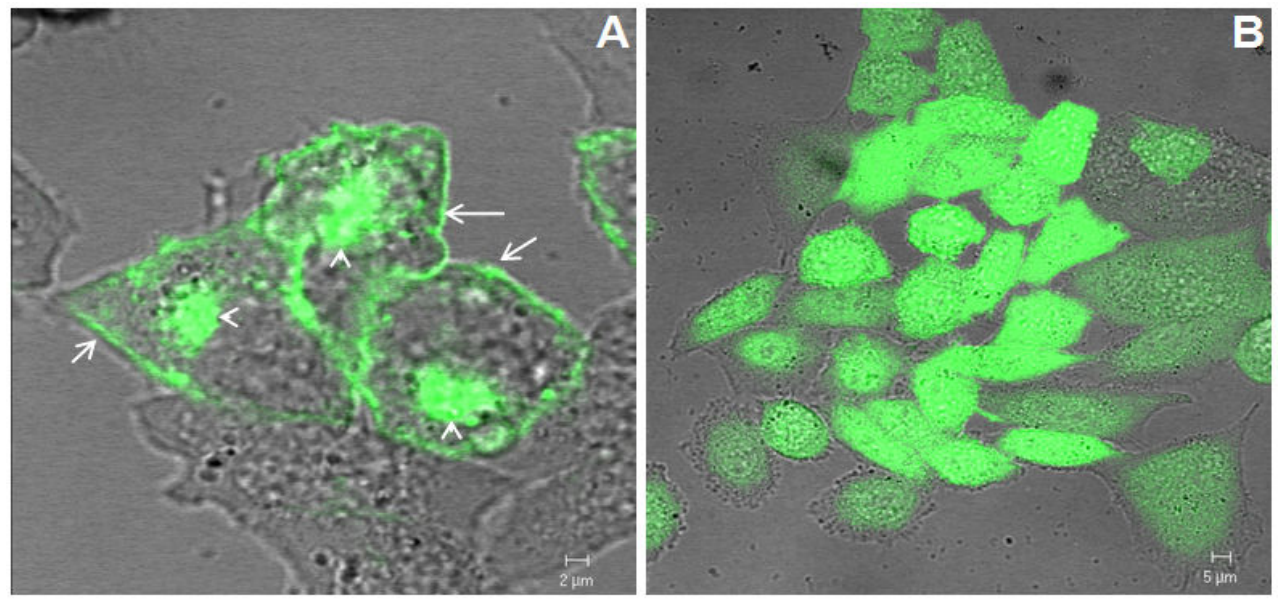

Figura 23. Análise da localização celular da PLP2 por microscopia confocal (aumento de 40x/1.3). A) Células $\mathrm{CHO}$ expressando a PLP2 fusionada com a EGFP. B) Células $\mathrm{CHO}$ controle expressando somente a EGFP.

Foi avaliada também, a localização celular em tempo real, onde foi possível verificar o aumento da proteína na região perinuclear após sua síntese (setas vermelhas) e o acúmulo da proteína na periferia das células (setas brancas), como mostrado na figura 24. Com este experimento, a hipótese de que a proteína após ser sintetizada no citoplasma da célula percorre um caminho passando pelo complexo de Golgi e retículo endoplasmático até sua chegada na membrana plasmática, ficou ainda mais evidenciado.

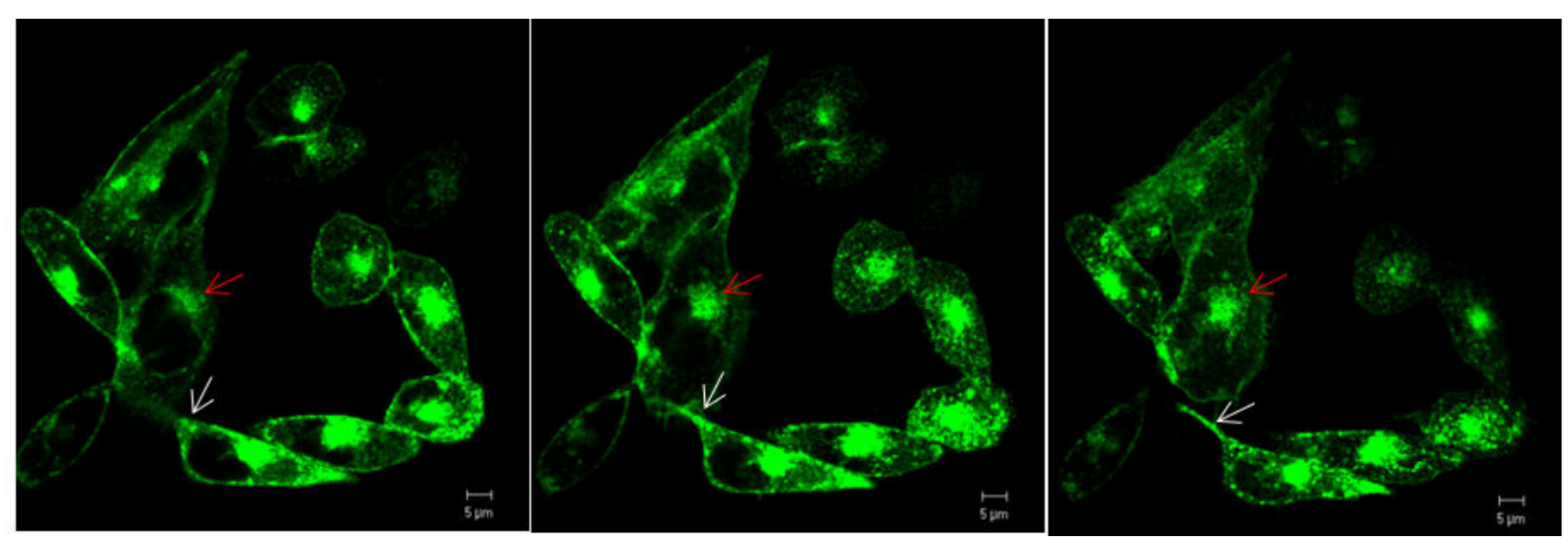

Figura 24. Análise em tempo real da localização da PLP2 fusionada com EGFP em células CHO por microscopia confocal (aumento de 40x/1.3). 


\section{DISCUSSÃo}

Os glioblastomas multiformes são os tumores cerebrais mais malignos dentre os gliomas de origem astrocítica e apesar das atuais abordagens terapêuticas, que inclui neurocirurgia seguida de quimioterapia combinada com radioterapia, o prognóstico típico não ultrapassa aproximadamente um ano (LOUIS, 2006). Recentemente, com o desenvolvimento maciço de novas tecnologias de seleções gênicas, fez com que surgissem novas tentativas de classificação de subgrupos de glioblastoma, tendo como base a análise dos perfis de expressão gênica para identificar novas ferramentas de diagnóstico ou prognóstico (COMINCINI et al., 2009) e com isso, está sendo possível refinar a classificação histomolecular de gliomas (DUCRAY; EL HALLANI; IDBAIH, 2009). A busca de potenciais marcadores moleculares entre vias aberrantes de transdução de sinais em glioblastomas é ativamente explorada para a otimização de terapias existentes ou o desenvolvimento de medicamentos inovadores (OHGAKI; KLEIHUES, 2007).

Avaliações do perfil de expressão em gliomas por microarray permitem análise simultânea de milhares de genes, sendo provável a identificação de genes associados com o grau do tumor, progressão e sobrevida do paciente (VAN DEN BOOM; WOLTER; KUICK, 2003; LIANG; DIEHN; WATSON, 2005). Este tipo de análise é um método bem estabelecido no estudo da expressão gênica de diferentes graus de tumores, pois possui grande potencial de selecionar genes que possam ser utilizados como marcadores tumorais (DYRSKJOT, 2003; SÁNCHEZ-CARBAYO, 2003; CUPERLOVIC-CULF; BELACEL; OUELLETTE, 2005).

Com o intuito de identificar genes associados com a invasão e a proliferação tumoral, Scrideli et al. (2008) estudaram recentemente o padrão de expressão de 10.000 genes de tumores astrocíticos, porém apenas 63 genes mostraram diferença de expressão maior que duas vezes quando foram comparados apenas GBM com AP. Com base nestes dados, encontramos o gene da PLP2 cuja expressão aumentada em glioblastomas foi visto pela primeira vez. Como tínhamos observado este aumento através da técnica de PCR em tempo real, queríamos saber se este aumento também ocorria ao nível protéico, tendo em vista que análise por PCR em tempo real só verifica o aumento de mRNA. 
Assim, neste trabalho, decidimos analisar a expressão desta proteína em GBM. Para tanto, inicialmente produzimos a PLP2 recombinante para que esta fosse usada na produção de anticorpos policlonais PLP2-específicos. Posteriormente, com o intuito de identificarmos a localização celular desta proteína, resolvemos expressála fusionada com a EGFP em células de mamífero e analisar a sua distribuição celular por microscopia confocal.

Para começar a produzir a proteína recombinante, inicialmente, clonamos a sequência da PLP2 no vetor PAE (RAMOS et al., 2001). Este vetor possui o promotor T7 $\left(\mathrm{P}_{\mathrm{T} 7}\right)$, que é reconhecido pela T7 RNA polimerase do fago $\lambda$, cujo gene desta polimerase encontra-se sob controle do promotor lacUV5 inserido no cromossomo das bactérias designadas como DE3, que é indutível por IPTG. Este vetor apresenta também uma sequência de 6 histidinas que é expresso em fusão com a proteína de interesse o que permite a posterior purificação com resina de afinidade.

Verificamos que, mesmo após várias tentativas de expressão, não havia crescimento das bactérias transformadas no meio de cultura, mesmo utilizando diferentes tipos de cepas bacterianas, indicando que a proteína estava sendo altamente tóxica.

Como a PLP2 é uma proteína de membrana (BREITWIESER et al., 1997; LEE et al., 2004), esta possui muitas regiões hidrofóbicas que poderiam estar prejudicando sua expressão. Assim sendo, decidimos analisar a sequência da PLP2 pelo software TMHMM Server v.2.0, para determinarmos as regiões hidrofílicas que representariam as alças externas desta proteína na membrana plasmática, ou seja, porções menores e mais expostas desta proteína, para que assim conseguíssemos expressá-la em bactérias. Dessa forma, além de eliminarmos as regiões hidrofóbicas, estas alças, representariam peptídeos que estariam mais propensos a serem reconhecidos por anticorpos que posteriormente seriam produzidos.

Esta análise nos revelou que a PLP2 possui quatro regiões transmembranares, assim como já descrito por Breitwieser et al. (1997), três supostas alças externas à membrana e duas alças internas. A sequência de nucleotídeos referentes a estas alças externas foram então sintetizadas (designada PLP2a) e posteriormente clonadas no vetor pAE para futura expressão. Embora, não tenhamos conseguido expressar a PLP2a nos diferentes tipos de bactérias 
testadas, as alças nas foram tóxicas, pois desta vez houve o crescimento bacteriano. Testamos diferentes quantidades de IPTG para indução $(0,1 \mathrm{mM}, 0,5$ $\mathrm{mM}, 1 \mathrm{mM}$ e $2 \mathrm{mM})$, assim como temperatura de crescimento mais baixa $\left(30^{\circ} \mathrm{C}\right)$, porém, não obtivemos sucesso (dados não mostrados).

Resolvemos, então clonar a PLP2a no vetor pSMT3, este é um vetor de expressão com 5.633 pb, onde na sua região 5' (N-terminal) encontra-se o His-Tag que é separado da proteína de fusão SUMO (PANAVAS; SANDERS; BUTT, 2009), cuja função é atuar como uma chaperona que facilita a solubilização e dobramento correto de proteínas clonadas neste vetor. Após a SUMO encontra-se o sítio de múltipla clonagem, onde o gene de interesse é inserido na região 3' (C-terminal) desta proteína, o vetor pSMT3 também possui o promotor T7 $\left(\mathrm{P}_{\mathrm{T} 7}\right)$.

A SUMO é uma proteína com 97 aminoácidos (aproximadamente 12 kDa) que modifica covalentemente outras proteínas nas células de muitos organismos, desde leveduras a células de mamíferos. A SUMO também é conhecida por outros nomes, como: BPF-1, Sentrin-1, SMT3 e UBL1 (HAY, 2005). A SUMO tem um grande número de funções biológicas dentre os quais incluem a repressão da transcrição (VERGER; PERDOMO; CROSSLEY, 2003), ciclo celular, apoptose, a localização intracelular e intra-nuclear e estabilidade da proteína (HAY, 2005).

Com a proteína fusionada, foi feito um novo teste de expressão em diferentes cepas bacterianas, e a PLP2a (SUMO/PLP2a) foi expressa somente em bactérias C43 (DE3). Estudos mostram que esta cepa tem maior capacidade de expressar proteínas de membrana quando comparadas com outras cepas de E. coli (DUMONSEIGNOVERT; CARIOT; VUILLARD, 2004; WAGNER et al., 2008).

Como a expressão da proteína SUMO/PLP2a foi bem sucedida, produzimos também a proteína SUMO para utilizar como controle nos experimentos, pois decidimos não clivar a SUMO da PLP2a para a produção dos anticorpos já que a SUMO poderia funcionar como uma proteína carreadora, aumentando assim a imunogenicidade da PLP2a na produção destes anticorpos.

Durante a ultima década, o método de peptide mass fingerprint (impressão digital da massa do peptídeo) evoluiu para uma técnica rápida e sensível para a identificação de proteínas e se tornou uma ferramenta indispensável para a investigação da proteômica (JAMES et al., 1993; MANN; HOJRUP; ROEPSTORFF, 1993; PAPPIN; HOJRUP; BLEASBY, 1993; YATES et al., 1993; HENZEL; 
WATANABE; STULTS, 2003). Dessa forma, decidimos utilizar esta metodologia para certificar que não houve término prematuro da PLP2a (proteína truncada) durante sua expressão.

Os resultados desta análise mostraram que foram encontrados o início da proteína (cauda de polihistidina), uma porção intermediária e a parte final da SUMO. Foi detectado também, o início da primeira alça, o final da segunda e o início da terceira alça correspondentes a PLP2. Estes resultados nos permite afirmar que a proteína SUMO/PLP2a estava sendo expressa pelo menos até o início da terceira alça da PLP2, mas não podemos afirmar que a terceira alça foi expressa até o final, pois não foram encontrados os peptídeos correspondentes ao final da proteína.

Para a produção dos anticorpos policlonais em camundongos foi utilizado o adjuvante hidróxido de alumínio, que forma agregados porosos que absorvem o antígeno em seus espaços intersticiais promovendo imunopotenciação, justificando seu efeito de depósito (MÉNDEZ et al., 2007). A natureza dos adjuvantes pode influenciar o tipo de resposta imune com ativação de subpopulações de células $T$ (Th1 ou Th2), induzindo resposta predominantemente celular ou humoral com produção de determinados isótipos de anticorpos (PAUL, 2003). Segundo Petrovsky e Aguilar (2004) o hidróxido de alumínio é um adjuvante potencializador da resposta de anticorpos e de células do tipo Th2.

Com a obtenção dos anticorpos anti-SUMO/PLP2a, foi decidido, utilizá-los para detectar a PLP2 nativa em glioblastomas através de testes de imunohistoquímica, mas os experimentos não foram bem sucedidos, pois o anticorpo não foi capaz de reconhecer a PLP2 (dados não mostrados). Uma provável explicação para este fato estaria baseada na resposta de anticorpos gerada pela imunização com a proteína PLP2 recombinante, ou seja, sem a conformação da proteína nativa e assim os anticorpos produzidos não seriam capazes de reconhecer epítopos expressos na proteína nativa.

Para testar estas hipóteses, avaliamos em testes de western blotting a capacidade destes anticorpos de reconhecer a proteína denaturada, portanto não apresentaria conformação tridimensional.

O soro anti-SUMO/PLP2a foi capaz de reconhecer uma banda na altura de 17 kDa, que é o tamanho esperado para a PLP2 nativa, em extratos celulares das células A172 e U87MG. Estas células são classificadas como uma linhagem celular 
de glioblastoma humano e nosso grupo já haviam realizado estudos de PCR em tempo real onde foi verificado o aumento da expressão gênica da PLP2. O soro antiSUMO não foi capaz de reconhecer nenhuma banda nos extratos celulares das mesmas células, mostrando que o reconhecimento não poderia ser inespecífico ou gerado pela presença da SUMO.

Este teste mostrou que a conformação da proteína PLP2 nativa parece ser importante para o reconhecimento pelos anticorpos que produzimos contra as alças da PLP2, indicando que estes anticorpos são eficientes contra a PLP2 somente em testes em que esta estiver denaturada, como no caso de western blotting.

Além disso, demonstramos que embora a SUMO seja uma proteína de fusão grande quando comparado às alças, não impediu a produção de anticorpos contra as alças da PLP2. Com estes resultados partimos para a identificação da proteína em tumores humanos, tendo em vista que até hoje não existem trabalhos mostrando que realmente a proteína é expressa em glioblastomas.

Nossos experimentos mostraram que os anticorpos anti-SUMO/PLP2a foram capazes de reconhecer uma banda na altura de $17 \mathrm{kDa}$ no extrato total de tumores humanos (GBM) e da linhagem celular U87MG e não reconheceu componentes do extrato total de tecido normal, mostrando que a expressão da proteína PLP2 é muito maior em glioblastomas. Estes dados comprovaram os resultados obtidos por nosso grupo que já tinha visto através de testes de microarray e PCR em tempo real. A presença aumentada da PLP2 em astrocitomas pode ser um indício do envolvimento desta proteína no processo tumorigênico uma vez que já foi relatado que ela se encontra associada ao receptor de quimiocina CCR1 (LEE et al., 2004). Este trabalho demonstrou também que a utilização de agentes quimiotáticos em células que super expressam a PLP2 promoveu o aumento da migração celular, indicando um papel funcional da PLP2 em processos quimiotáticos via CCR1.

Com o intuito de identificar a localização celular e o caminho percorrido pela PLP2 em células de mamífero, decidimos clonar e expressar a PLP2 inteira fusionada à EGFP em células CHO. A proteína EGFP (Enhanced Green Fluorescent Protein) emite fluorescência quando excitada em um comprimento de onda de 488 nm (com uma emissão máxima em 507 nm) e é uma proteína bastante utilizada como repórter para a visualização de outras proteínas a ela fusionada 
(NASCIMENTO et al., 2007; AHMED; HUANG; XIE, 2008; BURKHART et al., 2008; ASKAUTRUD et al., 2009; RIPOLL; BUNNELL, 2009).

Como a presença da EGFP poderia interferir na função da PLP2 dependendo se clonada na porção $\mathrm{N}$ ou C-terminal, pois dependendo da posição de fusão, o dobramento da PLP2 poderia ficar comprometido, portanto, decidimos utilizar dois vetores, um com a EGFP fusionada na porção N-terminal da PLP2 (pEGFPC3/PLP2) e outro com a EGFP fusionada à porção C-terminal (pEGFP-N1/PLP2). Feita a clonagem do gene da PLP2 nos dois vetores, foi realizada uma transfecção permanente em células $\mathrm{CHO}$ e U87MG. Nas células U87MG transfectadas verificamos a formação de somente três clones, um com o vetor pEGFP-N1/PLP2 e dois com o vetor pEGFP-C3/PLP2. Contudo nenhum deles apresentava fluorescência quando observados por microscopia confocal, indicando que somente a marca de resistência à geneticina estava sendo expressa. Muito provavelmente houve uma integração de parte do vetor em regiões não transcritas pelas células ou pode ter ocorrido a metilação do gene de interesse impedindo a expressão do mesmo.

As células $\mathrm{CHO}$, por outro lado, apresentaram vários clones e observamos por microscopia confocal, que grande parte destes estavam emitindo fluorescência, portanto estas células foram utilizadas nos experimentos posteriores. Decidimos utilizar somente as células $\mathrm{CHO}$ transfectadas com a construção pEGFP-N1/PLP2 (PLP2 fusionada a porção N-terminal da EGFP), pois a distribuição da expressão nas células transfectadas com pEGFP-C3/PLP2 (PLP2 fusionada a porção Cterminal da EGFP) ficou mais restrita ao núcleo, o que não seria um padrão esperado, indicando que a EGFP interferiu no dobramento da PLP2 ou bloqueando a região $\mathrm{N}$-terminal que poderia ser importante para o direcionamento desta proteína para a membrana celular mostrando, dessa forma, a importância de se utilizar diferentes abordagens no posicionamento da fusão com a EGFP.

Os experimentos mostraram que realmente a PLP2 se direciona para a membrana celular e que a proteína que não está na membrana encontra-se, em sua grande maioria, na região perinuclear da célula. Estes resultados podem ser um indício de que a PLP2, assim que sintetizada se direciona ao complexo de Golgi e retículo endoplasmático para depois ser transportada até a membrana como já mostrado em alguns trabalhos realizados com outras proteínas (HERNANDEZ- 
BLAZQUEZ et al., 2001; NASCIMENTO et al., 2007). Este indício ficou ainda mais evidente com o experimento que realizamos para verificar o trânsito da PLP2, onde podemos verificar a movimentação da proteína dentro das células passando pela região perinuclear e supostamente pelo reticulo endoplasmático antes de sua chegada até a membrana plasmática.

Com estes resultados demonstramos que esta proteína se direciona para a membrana plasmática com uma abordagem diferente do que já foi descrito na literatura onde a PLP2 foi clonada no vetor pcDNA3.1 e transfectadas em células HOS, este vetor expressa proteínas nele clonadas com um marcador chamado cMyc. Com essa abordagem só foi possível inferir que a PLP2 está na membrana plasmática utilizando anticorpos anti-c-Myc (LEE et al., 2004), mas este resultado não é totalmente aceito, tendo em vista que ele identificou somente o c-Myc e pode ser que somente o c-Myc esteja na membrana e não a PLP2. Em nosso experimento utilizamos um gene repórter para mostrar esta localização e assim conseguimos detectar a proteína não só na membrana, mas sua localização em toda a célula quando comparamos com células controle expressando somente a EGFP. A expressão da PLP2 em células de mamífero não só podem proporcionar maiores informações sobre o "traficking" desta proteína, mas também fornecer indícios se a sua alta expressão poderia influenciar na transformação maligna. 


\section{CONCLUSÕES}

1- A PLP2 recombinante não foi obtida em sistema bacteriano, mesmo utilizando diferentes cepas bacterianas.

2- A proteína recombinante somente foi obtida quando clonada as regiões correspondentes as alças externas desta proteína e fusionada à proteína SUMO.

3- O reconhecimento da PLP2 nativa pelos anticorpos policlonais em tumores humanos (glioblastomas) e o não reconhecimento em tecidos humano não tumoral permite comprovar que realmente a PLP2 está sendo altamente expressa em glioblastomas, e não somente o seu RNA mensageiro.

4- Os testes de transfecção em células CHO com a EGFP fusionada à PLP2 na sua porção C-terminal e o estudo do seu tráfego dentro das células, mostraram que assim que sintetizada esta proteína é direcionada para a região perinuclear e depois transportada para a membrana plasmática.

5- Os resultados sugerem fortemente que esta proteína parece estar envolvida de alguma forma no processo tumorigênico e que possa ser usada futuramente como um possível marcador tumoral. 


\section{REFERÊNCIAS*}

AHMED, M. M.; HUANG, T. H.; XIE, Q. D. A sensitive and rapid assay for investigating vertical transmission of hepatitis $B$ virus via male germ line using EGFP Vector as reporter. J. Biomed. Biotechnol., v. 2008, p. 1-6, 2008.

ASKAUTRUD, H. A.; GJERNES, E.; STØRVOLD, G. L.; LINDEBERG, M. M.; THORSEN, J.; PRYDZ, H.; FRENGEN, E. Regulated expression of a transgene introduced on an oriP/EBNA-1 PAC shuttle vector into human cells. BMC Biotechnol., v.88, p. 1-9, 2009.

BAGGIOLINI, M. Chemokines in pathology and medicine. J. Internal. Med., v. 250, p. 91-104, 2001.

BARBOSA, K. C.; OBA-SHINJO, S. M.; UNO, M.; CARVALHO, P. O.; ROSEMBERG, S.; AGUIAR, P. H.; CARLOTTI, C. G.; MALHEIROS, S. M.; TOLEDO, S.; LOTUFO, P.; MARIE, S. K. Association of EGFR c.2073A>T polymorphism with decreased risk of diffusely infiltrating astrocytoma in a Brazilian case-control study. Intern. J. Biol. Markers, v. 23, p. 140-146, 2008.

BHANDARI, P.; GOWRISHANKAR, J. An Escherichia coli host strain useful for efficient overproduction of cloned gene products with $\mathrm{NaCl}$ as the inducer. J. Bact., v. 179, p. 4403-6, 1997.

BRADFORD, M. M. A rapid and sensitive method for the quantitation of microgram quantities of protein utilizing the principle of protein-dye binding. Anal. Biochem., v. 72, p. 248-54, 1976.

BREITWIESER, G. E.; MCLENITHAN, J. C.; CORTESE, J. F.; SHIELDS, J. M.; OLIVA, M. M.; MAJEWSKI, J. L.; MACHAMER, C. E.; YANG, V. W. Colonic epithelium-enriched protein $A 4$ is a proteolipid that exhibits ion channel characteristics. Am. J. Physiol., v. 272, p. 957-65, 1997.

BRENTANI, H.; CABALLERO, O. L.; CAMARGO, A. A.; DA SILVA, A. M.; DA SILVA, W. A.; DIAS NETO, E.; GRIVET, M.; GRUBER, A.; GUIMARAES, P. E.; HIDE, W.; ISELI, C.; JONGENEEL, C. V.; et al. The generation and utilization of a canceroriented representation of the human transcriptome by using expressed sequence tags. Proc. Natl. Acad. Sci. USA, v. 100, p. 13418-23, 2003.

* De acordo com: ASSOCIÇÃO BRASILEIRA DE NORMAS TÉCNICAS. NBR 6023: Informação e documentação: referências: elaboração. Rio de Janeiro, 2002. 
BURKHART, D. L.; VIATOUR, P.; HO, V. M.; SAGE, J. GFP reporter mice for the retinoblastoma-related cell cycle regulator p107. Cell Cycle, v. 7, p. 2544-52, 2008.

BUTT, T. R.; EDAVETTAL, S. C.; HALL, J. P.; MATTERN, M. R. SUMO fusion technology for difficult-to-express proteins. Protein Expr. Purif., v. 43, p. 1-9, 2005.

COLIN, C.; BAEZA, N.; BARTOLI, C.; FINA, F.; EUDES, N.; NANNI, I.; MARTIN, P. M.; OUAFIK, L.; FIGARELLA-BRANGER, D. Identification of genes differentially expressed in glioblastoma versus pilocytic astrocytoma using suppression subtractive hybridization. Oncogene, v. 25, p. 2818-26, 2006.

COLLINS, V. P. Brain tumors: classification and genes. J. Neurol. Neurosurg. Psychiatry, v. 75, p. 2-11, 2004.

COMINCINI, S.; PAOLILLO, M.; BARBIERI, G.; PALUMBO, S.; SBALCHIERO, E.; AZZALIN, A.; RUSSO, M. A.; SCHINELLI, S. Gene expression analysis of an EGFR indirectly related pathway identified PTEN and MMP9 as reliable diagnostic markers for human glial tumor specimens. J. Biomed. Biotechnol., v. 2009, p. 1-12, 2009.

COTRAN, R. S.; KUMAR, V.; COLLINS, T. Robbins patologia estrutural e funcional. 6. ed. Rio de Janeiro: Guanabara Koogan, 2000. 1251 p. ISBN 8527705915.

CUPERLOVIC-CULF, M.; BELACEL, N.; OUELLETTE, R. J. Determination of tumour marker genes from gene expression data. Drug Discov. Today, v. 10, p. 429-37, 2005.

DAUMAS-DUPORT, C.; SCHEITHAUER, B.; O'FALLON, J.; KELLY, P. Grading of astrocytomas. A simple and reproducible method. Cancer, v. 62, p. 2152-65, 1988.

DUCRAY, F.; EL HALLANI, S.; IDBAIH, A. Diagnostic and prognostic markers in gliomas. Curr. Opin. Oncol., v. 21, p. 537-42, 2009.

DUMON-SEIGNOVERT, L.; CARIOT, G.; VUILLARD, L. The toxicity of recombinant proteins in Escherichia coli: a comparison of overexpression in BL21(DE3), C41(DE3), and C43(DE3). Protein Expr. Purif., v. 37, p. 203-6, 2004.

DYRSKJOT, L. Classification of bladder cancer by microarray expression profiling: towards a general clinical use of microarrays in cancer diagnostics. Expert. Rev. Mol. Diagn., v. 3, p. 635-47, 2003. 
GRIGORIADIS, A.; MACKAY, A.; REIS-FILHO, J. S.; STEELE, D.; ISELI, C.; STEVENSON, B. J.; JONGENEEL, C. V.; VALGEIRSSON, H.; FENWICK, K.; IRAVANI, M.; LEAO, M.; SIMPSON, A. J.; et al. Establishment of the epithelialspecific transcriptome of normal and malignant human breast cells based on MPSS and array expression data. Breast Cancer Res., v. 8, p. 1-15, 2006.

HAY, R. T. SUMO: a history of modification. Mol. Cell., v. 18, p. 1-12, 2005. Review.

HENZEL, W. J.; WATANABE, C.; STULTS, J. T. Protein identification: the origins of peptide mass fingerprinting. J. Am. Soc. Mass Spectrom., v. 14, p. 931-42, 2003.

HERNANDEZ-BLAZQUEZ, F. J.; JOAZEIRO, P. P.; OMORI, Y.; YAMASAKI, H. Control of intracellular movement of connexins by E-cadherin in murine skin papilloma cells. Exp. Cell Res., v. 270, p. 235-47, 2001.

HSU, D. W.; LOUIS, D. N.; EFIRD, J. T.; HEDLEY-WHYTE, E. T. Use of MIB-1 (Ki$67)$ immunoreactivity in differentiating grade II and grade III gliomas. J. Neuropathol. Exp. Neurol., v. 56, p. 857-65, 1997.

JAMES, P.; QUADRONI, M.; CARAFOLI, E.; GONNET, G. Protein identification by mass profile fingerprinting. Biochem. Biophys. Res. Commun., v. 195, p. 58-64, 1993.

JONGENEEL, C. V.; ISELI, C.; STEVENSON, B. J.; RIGGINS, G. J.; LAL, A.; MACKAY, A.; HARRIS, R. A.; O'HARE, M. J.; NEVILLE, A. M.; SIMPSON, A. J.; STRAUSBERG, R. L. Comprehensive sampling of gene expression in human cell lines with massively parallel signature sequencing. Proc. Natl. Acad. Sci. USA, v. 100, p. 4702-5, 2003.

KELLOGG COMMUNITY COLLEGE. Learning the Nervous System. Disponível em:<http://academic.kellogg.edu/herbrandsonc/bio201_McKinley/f146_cellular_organ iza_c.jpg>. Acesso em: 26 fev. 2010.

KHATUA, S.; PETERSON, K. M.; BROWN, K. M.; LAWLOR, C.; SANTI, M. R.; LAFLEUR, B.; DRESSMAN, D.; STEPHAN, D. A.; MACDONALD, T. J. Overexpression of the EGFR/FKBP12/HIF-2alpha pathway identified in childhood astrocytomas by angiogenesis gene profiling. Cancer Res., v. 63, p. 1865-70, 2003.

KLEIHUES, P.; LOUIS, D. N.; SCHEITHAUER, B. W.; RORKE, L. B.; REIFENBERGER, G.; BURGER, P. C.; CAVENEE, W. K. The WHO classification of tumors of the nervous system. J. Neuropathol. Exp. Neurol., v. 61, p. 215-25, 2002. 
KORSHUNOV, A.; SYCHEVA, R.; GOLANOV, A. The prognostic relevance of molecular alterations in glioblastomas for patients age $<50$ years. Cancer, v. 104, p. 825-32, 2005.

LAEMMLI, U. K. Cleavage of structural proteins during the assembly of the head of bacteriophage T4. Nature, v. 227, p. 680-85, 1970.

LEE, S. M.; SHIN, H.; JANG, S. W.; SHIM, J. J.; SONG, I. S.; SON, K. N.; HWANG, J.; SHIN, Y. H.; KIM, H. H.; LEE, C. K.; KO, J.; NA, D. S.; KWON, B. S.; KIM, J. PLP2/A4 interacts with CCR1 and stimulates migration of CCR1-expressing HOS cells. Biochem. Biophys. Res. Commun., v. 324, p. 768-72, 2004.

LIANG, Y.; DIEHN, M.; WATSON, N.; et al. Gene expression profiling reveals molecularly and clinically distinct subtypes of glioblastoma multiforme. Proc. Natl. Acad. Sci. USA, v. 102, p. 5814-9, 2005.

LOUIS, D. N. A molecular genetic model of astrocytoma histopathology. Brain Pathol., v. 7, p. 755-64, 1997.

LOUIS, D. N. Molecular pathology of malignant gliomas. Annual Review of Pathology, v. 1, p. 97-117, 2006. Review.

LOUIS, D. N.; OHGAKI, H.; WIESTLER, O. D.; CAVENEE, W. K. (eds). WHO classification of tumours of the central nervous system. IARC, Lyon, 2007a.

LOUIS, D. N.; OHGAKI, H.; WIESTLER, O. D.; CAVENEE, W. K.; BURGER, P. C.; JOUVET, A.; SCHEITHAUER, B. W.; KLEIHUES, P. The 2007 WHO classification of tumours of the central nervous system. Acta Neuropathol., v. 114, p. 97-109, 2007b. Review.

MANN, M.; HOJRUP, P.; ROEPSTORFF, P. Use of mass spectrometric molecular weight information to identify proteins in sequence databases. Biol. Mass Spectrom., v. 22, p. 338-345, 1993.

MCKINNEY, P. A. Brain tumors: incidence, survival, and aetiology. J. Neurol. Neurosurg. Psychiatry, v. 75, p. 12-17, 2004. 
MÉNDEZ, I. Z. R.; SHI, Y.; HOGENESCH, H.; HEM, S. L. Potentiation of the immune response to non-adsorbed antigens by aluminum-containing adjuvants. Vaccine, $v$. 25, p. 825-33, 2007.

MIROUX, B.; WALKER, J. E. Over-production of proteins in Escherichia coli: mutant hosts that allow synthesis of some membrane proteins and globular proteins at high levels. J. Mol. Biol., v. 260, p. 289-98, 1996.

MURDOCH, C.; FINN, C. Chemokine receptors and their role in inflammation and infectious diseases. Blood, v. 95, p. 3032-43, 2000.

MYERS, S. J.; WONG, L. M.; CHARO, I. F. Signal transduction and ligand specificity of the human monocyte chemoattract and protein-1 receptor in transfected embryonic kidney cells, J. Biol. Chem., v. 270, p. 5786-92, 1995.

NASCIMENTO, F. D.; HAYASHI, M. A.; KERKIS, A.; OLIVEIRA, V.; OLIVEIRA, E. B.; RÁDIS-BAPTISTA, G.; NADER, H. B.; YAMANE, T.; TERSARIOL, I. L.; KERKIS, I. Crotamine mediates gene delivery into cells through the binding to heparan sulfate proteoglycans. J. Biol. Chem., v. 282, p. 21349-60, 2007.

OBA-SHINJO, S. M.; BENGTSON, M. H.; WINNISCHOFER, S. M.; COLIN, C.; VEDOY, C. G.; DE MENDONÇA, Z.; MARIE, S. K.; SOGAYAR, M. C. Identification of novel differentially expressed genes in human astrocytomas by CDNA representational difference analysis. Mol. Brain Research, v. 140, p. 25-33, 2005.

OHGAKI, H.; KLEIHUES, P. Genetic pathways to primary and secondary glioblastoma. Am. J. Pathol., v. 170, p. 1445-53, 2007. Review.

OLIVA, M. M.; WU, T. C.; YANG, V. W. Isolation and characterization of a differentiation-dependent gene in the human colonic cell line HT29-18. Arch. Biochem. Biophys., v. 302, p. 183-92, 1993.

PANAVAS, T.; SANDERS, C.; BUTT, T. R. SUMO fusion technology for enhanced protein production in prokaryotic and eukaryotic expression systems. Meth. Mol. Biol., v. 497, p. 303-17, 2009.

PAPPIN, D. J.; HOJRUP, P.; BLEASBY, A. J. Rapid identification of proteins by peptide-mass fingerprinting. Curr. Biol., v. 3, p. 327-32, 1993. 
PAUL, W. E. Fundamental Immunology. $5^{\mathrm{a}}$ ed. Lippincott Williams \& Wilkins. Philadelphia, p. 1337-42, 2003.

PEACE, J. E.; WANG, J.; PONATH, P. D.; MURPHY, P. M. The N-terminal extracellular segments of the chemokine receptors CCR1 and CCR3 are determinants for MIP-1a and extaxin binding, respectively, but a second domain is essential for efficient receptor activation. J. Biol. Chem., v. 273, p. 19972-76, 1998.

PETROVSKY, N.; AGUILAR, J. C. Vaccine adjuvants: current state and future trends. Immunol. Cell Biol., v. 82, p. 488-96, 2004.

PORATH, J.; OLIN, B. Immobilized metal ion affinity adsorption and immobilized metal ion affinity chromatography of biomaterials. Serum protein affinities for gelimmobilized iron and nickel ions. Biochemistry, v. 22, p. 1621-30, 1983.

RAMOS, C. R.; VILAR, M. M.; NASCIMENTO, A. L.; HO, P. L.; THAUMATURGO, N.; EDELENYI, R.; ALMEIDA, M.; DIAS, W. O.; DIOGO, M.; TENDLER, M. r-Sm14 pRSETA efficacy in experimental animals. Mem. Inst. Oswaldo Cruz, v. 96, p. 13135, 2001.

RHODES, D. R.; YU, J.; SHANKER, K.; DESHPANDE, N.; VARAMBALLY, R.; GHOSH, D.; BARRETTE, T.; PANDEY, A.; CHINNAIYAN, A. M. Large-scale metaanalysis of cancer microarray data identifies common transcriptional profiles of neoplastic transformation and progression. Proc. Natl. Acad. Sci. USA, v. 101, p. 9309-14, 2004.

RICKMAN, D. S.; BOBEK, M. P.; MISEK, D. E.; KUICK, R.; BLAIVAS, M.; KURNIT, D. M.; TAYLOR, J.; HANASH, S. M. Distinctive molecular profiles of high-grade and low-grade gliomas based on oligonucleotide microarray analysis. Cancer Res., v. 61, p. 6885-91, 2001.

RIPOLL, C. B.; BUNNELL, B. A. Comparative characterization of mesenchymal stem cells from eGFP transgenic and non-transgenic mice. BMC Cell Biol., v. 10, p. 1-12, 2009.

ROSS, M.; GRAFHAM, D.; COFFEY, A.; SCHERER, S.; MCLAY, K.; MUZNY, D.; PLATZER, M.; HOWELL, G.; BURROWS, C.; BIRD, C.; et al. The DNA sequence of the human $X$ chromosome. Nature, v. 434, p. 325-37, 2005.

SÁNCHEZ-CARBAYO, M. Use of high-throughput DNA microarrays to identify biomarkers for bladder cancer. Clin. Chem., v. 49, p. 23-31, 2003. 
SANCHEZ-PULIDO, L.; MARTIN-BELMONTE, F.; VALENCIA, A.; ALONSO, M. A. MARVEL: a conserved domain involved in membrane apposition events. Trends Biochem. Sci., v. 27, p. 599-601, 2002. Review.

SCRIDELI, C. A.; CARLOTTI, C. G. JR.; OKAMOTO, O. K.; ANDRADE, V. S.; CORTEZ, M. A.; MOTTA, F. J.; LUCIO-ETEROVIC, A. K.; NEDER, L.; ROSEMBERG, S.; OBA-SHINJO, S. M.; MARIE, S. K.; TONE, L. G. Gene expression profile analysis of primary glioblastomas and non-neoplastic brain tissue: identification of potential target genes by oligonucleotide microarray and real-time quantitative PCR. J. Neurooncol., v. 88, p. 281-91, 2008.

SHEVCHENKO, A.; WILM, M.; VORM, O.; MANN, M. Mass spectrometric sequencing of proteins silver-stained polyacrylamide gels. Anal. Chem., v. 68, p. 850-58, 1996.

THEAKSTON, R. D. G.; LLOYD-JONES, M. J.; REID, H. A. Micro-ELISA for detecting and assying snake venom and anti-venom antibody. Lancet, v. 2, p. 63941, 1977.

UNO, M.; OBA-SHINJO, S. M.; DE AGUIAR, P. H.; LEITE, C. C.; ROSEMBERG, S.; MIURA, F. K.; JUNIOR, R. M.; SCAFF, M.; MARIE, S. K. N. Detection of somatic TP53 splice site mutations in diffuse astrocytomas. Cancer Letters, v. 224, p. 321$27,2005$.

VAN DEN BOOM, J.; WOLTER, M.; KUICK, R.; et al. Characterization of gene expression profiles associatedwith glioma progression using oligonucleotide-based microarray analysis and real-time reverse transcription-polymerase chain reaction. Am. J. Pathol., v. 163, p. 1033-43, 2003.

VELCULESCU, V. E.; ZHANG, L.; VOGELSTEIN, B.; KINZLER, K. W. Serial analysis of gene expression. Science, v. 270, p. 484-7, 1995.

VERGER, A.; PERDOMO, J.; CROSSLEY, M. Modification with SUMO. A role in transcriptional regulation. EMBO Rep., v. 4, p. 137-42, 2003.

VON DEIMLING, A.; LOUIS, D. N.; SCHRAMM, J.; WIESTLER, O. D. Astrocytic gliomas: characterization on a molecular genetic basis. Rec. Res. Cancer Res., v. 135, p. 33-42, 1994. 
VON DEIMLING, A.; VON AMMON, K.; SCHOENFELD, D.; WIESTLER, O. D.; SEIZINGER, B. R.; LOUIS, D. N. Subsets of glioblastoma multiforme defined by molecular genetic analysis. Brain Pathol., v. 3, p. 19-26, 1993.

WAGNER, S.; KLEPSCH, M. M.; SCHLEGEL, S.; APPEL, A.; DRAHEIM, R.; TARRY, M.; HÖGBOM, M.; VAN WIJK, K. J.; SLOTBOOM, D. J.; PERSSON, J. O.; DE GIER, J. W. Tuning Escherichia coli for membrane protein overexpression. Proc. Natl. Acad. Sci. USA, v. 105, p. 14371-6, 2008.

YATES, J. R.; SPEICHER, S.; GRIFFIN, P. R.; HUNKAPILLER, T. Peptide mass maps: a highly informative approach to protein identification. Anal Biochem., v. 214, p. 397-408, 1993.

ZHANG, L.; JIE, C.; OBIE, C.; ABIDI, F.; SCHWARTZ, C. E.; STEVENSON, R. E.; VALLE, D.; WANG, T. $X$ chromosome cDNA microarray screening identifies a functional PLP2 promoter polymorphism enriched in patients with X-linked mental retardation. Genome Res., v. 17, p. 641-8, 2007. 